
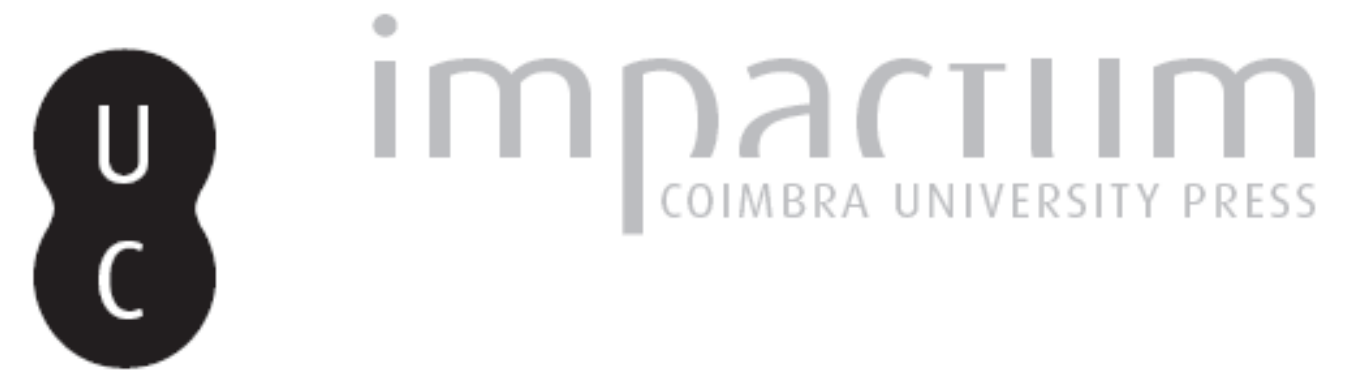

\title{
A estrada Emínio-Talábriga-Cale: relações com a geografía e o povoamento de Entre Douro e Mondego
}

\author{
Autor(es): $\quad$ Lopes, Luís Seabra
}

Publicado por: Imprensa da Universidade de Coimbra

URL persistente:

URI:http://hdl.handle.net/10316.2/45376

DOI:

DOI:https://dx.doi.org/10.14195/1647-8657_39_6

Accessed : $\quad$ 26-Apr-2023 07:41:05

A navegação consulta e descarregamento dos títulos inseridos nas Bibliotecas Digitais UC Digitalis, UC Pombalina e UC Impactum, pressupõem a aceitação plena e sem reservas dos Termos e Condições de Uso destas Bibliotecas Digitais, disponíveis em https://digitalis.uc.pt/pt-pt/termos.

Conforme exposto nos referidos Termos e Condições de Uso, o descarregamento de títulos de acesso restrito requer uma licença válida de autorização devendo o utilizador aceder ao(s) documento(s) a partir de um endereço de IP da instituição detentora da supramencionada licença.

Ao utilizador é apenas permitido o descarregamento para uso pessoal, pelo que o emprego do(s) título(s) descarregado(s) para outro fim, designadamente comercial, carece de autorização do respetivo autor ou editor da obra.

Na medida em que todas as obras da UC Digitalis se encontram protegidas pelo Código do Direito de Autor e Direitos Conexos e demais legislação aplicável, toda a cópia, parcial ou total, deste documento, nos casos em que é legalmente admitida, deverá conter ou fazer-se acompanhar por este aviso.

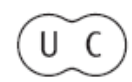


UNIVERSIDADE DE COIMBRA

FACULDADE DE LETRAS

\section{CONIMBRIGA}

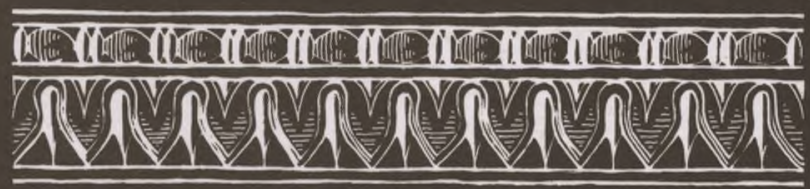

VOLUME XXXIX - 2000 


\section{Luís SEABRa LOPES}

Doutorado em Engenharia Electrotécnica pela Universidade Nova de Lisboa.

Professor na Universidade de Aveiro, Departamento de Electrónica e Telecomunicações

\section{A ESTRADA EMÍNIO-TALÁBRIGA-CALE}

Relações com a Geografia e o Povoamento de Entre Douro e Mondego

“Conimbriga" XXXIX (2000) p. 191-258

RESUMO: Neste artigo estuda-se o traçado da estrada que ligava, na época romana, as cidades de Emínio (Coimbra) e Cale (Porto/Gaia). O traçado que se propõe, bem diferente do traçado da estrada coimbrã ou da moderna estrada nacional, baseia-se na interpretação da evolução do povoamento e das condições geomorfológicas da região de entre Douro e Mondego desde a época romana. Naturalmente, são também tidas em conta as referências a estradas contidas na documentação medieval. A falta de uma solução consensual para o problema da localização de Talábriga tem sido o principal factor de incerteza quanto ao traçado da estrada romana. A contagem das 40 milhas de distância de Emínio a Talábriga ao longo do itinerário proposto leva a situar Talábriga no Marnel, sendo esta precisamente a hipótese para que apontam todos os outros elementos conhecidos.

ABSTRACT: In this paper, the course of the road linking the Roman cities Aeminium (Coimbra) and Cale (Porto/Gaia) is investigated. The proposed road course, quite different from the course of the so-called estrada coimbrã or of the modem national road, is reconstructed based on an interpretation of the evolution of population settlements and geomorphologic conditions. References to roads contained in medieval documents are also taken into account. The difficulty in locating the Talabriga city has been the main uncertainty factor about the course of the roman road. Counting the 40 miles distance between Aeminium and Talabriga along the proposed road course leads to locating Talabriga in modern Marnel. This hypothesis is also supported by all other evidences gathered until now. 
(Página deixada propositadamente em branco) 


\section{A ESTRADA EMÍNIO-TALÁBRIGA-CALE Relações com a Geografia e o Povoamento de Entre Douro e Mondego}

\section{Introdução}

A rede viária foi uma das marcas mais significativas deixadas pelo poder de Roma nos territórios que dominou. Através da rede viária, Roma fazia chegar mais rapidamente, a qualquer ponto do seu vastíssimo império, os exércitos que o mantinham coeso. A rede viária era também a infraestrutura essencial para que o Império pudesse ser eficazmente administrado e explorado. $\mathrm{O}$ objectivo era, evidentemente, o enriquecimento dos conquistadores através do comércio e transformação das riquezas dos territórios conquistados. Com o tempo, as grandes vias que suportavam esse comércio levaram, por sua vez, a uma maior abertura das economias dos povos indígenas, ao desenvolvimento de novos centros urbanos e a uma exploração agrícola mais organizada, por forma a fornecer a esses centros urbanos os géneros necessários.

Naturalmente, grande parte da rede viária deixada pelos Romanos já existia, numa forma primitiva, desde tempos ancestrais. Os caminhos principais são caminhos naturais, sugeridos pelas condições do terreno e calcorreados desde sempre pelo homem. O que os Romanos fizeram foi melhorar as condições de circulação através do alargamento e nivelação das vias, da melhoria do pavimento, por vezes empedrando-o, da construção de pontes, da colocação de miliários, etc. Onde havia veredas desconfortáveis e sinuosas, construíram estradas. Posições fortificadas situadas ao longo das vias principais zelavam pela segurança da circulação e defendiam o território de possíveis invasões que por essas mesmas vias se aproximassem. A construção de uma grande via era considerada um feito tão notável como uma vitória militar ou um 
acto político relevante e era, por vezes, assinalada através de monumentos comemorativos.

Em Portugal, uma das principais vias romanas era a que ligava Olisipo, município de cidadãos romanos, a Brácara Augusta, sede de um dos conventos da Tarraconense e, a partir de finais do século III d. C, capital da nova província da Calécia. A estrada passava ainda pela colónia de Escálabis, sede de um dos conventos da Lusitânia e importante centro vial, e por Conímbriga, outro centro vial importante onde aliás se documenta o culto aos Lares Viales.

A reconstituição do traçado da estrada

Brácara tem colocado diversos problemas difíceis de resolver. Os mais difíceis são, aliás, os que dependem da localização das cidades tocadas pela estrada. Se a localização de Conímbriga foi determinada em finais do século XIX, já as localizações de Escálabis e de Talábriga têm continuado a suscitar teorias divergentes até ao presente.

Uma das primeiras contribuições para o esclarecimento dos traçados das principais estradas romanas em território português ficou a dever-se a costa Veiga (1943). Trata-se de um pequeno mas bem informado trabalho com propostas ou sugestões ainda hoje dignas de consideração. Com o rigor que é seu timbre, alarcão (1967; 1970; 1988a, I, p. 49-61; 1988b) tem também delineado as directrizes seguidas pelas principais estradas romanas.

Mário Saa publicou uma obra em seis volumes em que examina exaustivamente os traçados das vias da Lusitânia. Foi este o primeiro estudo de fôlego sobre a rede viária e o Itinerário de Antonino no actual território português. Ainda hoje é útil, embora mais pela abundância de informação, muita da qual directamente pesquisada pelo autor no terreno, do que pelas interpretações e propostas de solução, que são frequentemente inaceitáveis. O traçado da estrada entre Olisipo e Brácara Augusta é tratado nos volumes II e III (SAA, 1959; 1960).

$\mathrm{Na}$ sua tese de doutoramento, Vasco Mantas estudou as ligações viárias entre Olisipo e Brácara (Mantas, 1996). Embora não possa concordar com algumas das soluções apresentadas, não deixa esta tese de ser extremamente útil, por constituir uma síntese actualizada de informação relativa à rede viária romana na faixa atlântica do território português a norte do Tejo.

O presente artigo centra-se nos três segmentos da estrada compreendidos entre Emínio (Coimbra) e Cale (Porto/Gaia). O primeiro estudo de fundo sobre esta parte da estrada ficou a dever-se a ALves 
Pereira (1907). Este autor demonstrou pela primeira vez que a estrada não passava em Aveiro, mas sim mais pelo interior. Costa Veiga (1943) acrescentou diversas observações pertinentes quanto a este problema.

Diversos estudiosos da arqueologia e história regionais têm dado contribuições para o estudo da rede viária romana e medieval desta região, nomeadamente Rocha Madahil (1941), J. Sousa Baptista (1942), Oliveira (1943), A. Sousa Baptista $(1947 ; 1948 ; 1958$; 1959), Nogueira Gonçalves (1959; 1967; 1981), Ladeira (1982), Castro (1987), Mattoso, Krus \& andrade (1993).

O meu interesse por este problema surgiu em 1992. Andava eu nessa altura a preparar uma monografia sobre São João da Azenha, localidade situada na margem direita do rio Cértima, entre Avelãs do Caminho e Aguada de Baixo. Sabia-se que a estrada coimbrã, mais tarde chamada estrada real, havia passado em São João da Azenha até meados do século XIX. Em face de diversos vestígios de uma estrada antiga, larga e de boa construção, dizia-se que ali teria passado também a estrada romana. Tratei de verificar os fundamentos de tal suposição e rapidamente me apercebi de que tudo estava em aberto, por não estar ainda resolvido o problema da localização de Talábriga.

Achei este último problema tão interessante e importante para a história do Baixo Vouga que não resisti a procurar a sua solução. A investigação do traçado da estrada começou pela inventariação das referências medievais a estradas e, em especial, pela reconstituição do traçado da estrada mourisca, que, até ao século XII, ligou Portucale e Colimbria (SEabra Lopes, 1994ab). Quanto a Talábriga, recolhi uma série de elementos que apoiam, se é que não demonstram, a sua localização no Marnel, concelho de Águeda (Seabra Lopes, 1995; 1996ab; 1997a).

Neste artigo, apresento a minha solução para o problema do traçado da estrada romana, bem diferente do traçado tradicionalmente considerado o mais provável. Esta solução já foi apresentada abreviadamente numa pequena publicação autónoma (SEABra Lopes, 1997b).

Começarei por apresentar algumas considerações sobre as relações entre a geografia, o povoamento e a rede viária, bem como os elementos que pude recolher sobre a evolução geomorfológica da região estudada. Quatro itinerários alternativos serão inicialmente considerados para a ligação de Emínio a Talábriga, que é a que suscita maiores dúvidas. A cronologia da utilização desses itinerários é estudada, tendo 
em conta as referências medievais a estradas e a evolução geomorfológica e da estrutura do povoamento da região do Vouga. Finalmente, descreve-se em pormenor o traçado considerado mais provável para toda a estrada entre Emínio e Cale.

\section{Relações gerais entre a geografía, a rede viária e o povoamento}

São extremamente interessantes de analisar as relações entre a geografia, o povoamento e a rede viária numa certa região. Os grandes itinerários foram certamente desbravados pelo homem nómada, nas suas deambulações, por espaços relativamente vastos, em busca de alimento. A emergência da agricultura como principal suporte da subsistência humana levou à sedentarização dos povos primitivos e, consequentemente, à formação de povoados.

$\mathrm{O}$ aumento da população e a rivalidade entre povos vizinhos levou a uma delimitação territorial progressivamente mais nítida. A necessidade de defender os territórios levou ao surgimento de povoações fortificadas. A necessidade de coordenar esforços de vária índole levou à criação de hierarquias territoriais, atribuindo-se a cada unidade territorial uma capital.

Nas cidades capitais de territórios se acumulavam políticos, burocratas e militares. O número destes indivíduos era tanto maior quanto maior fosse a importância de uma cidade e, como não produziam os bens necessários à sua subsistência, adquiriam-nos na periferia rural da cidade. Assim se estabelecia um fluxo comercial das pequenas povoações para os grandes centros. Obviamente, os grandes centros urbanos, e mesmo as pequenas povoações rurais, consumiam outro género de produtos, fossem eles armas, utensílios vários, objectos de adorno ou matérias-primas. As necessidades de administração territorial e as trocas comerciais desenhavam uma rede de caminhos que mantinha em contacto as cidades, as comunidades agrárias, os locais de extracção de matérias-primas, etc. A rede viária de uma região é, pois, uma das mais interessantes manifestações do seu tecido económico.

Normalmente, os grandes centros surgiam em locais estratégicos, isto é, locais com boas condições defensivas, normalmente em pontos altos, centrais em relação aos territórios a que presidiam e, frequentemente, no cruzamento de vias importantes. Uma vez que os rios também eram utilizados como vias de comunicação, os grandes centros 
surgiam, por vezes, no cruzamento de grandes vias com rios. Naturalmente, o caminho de ligação entre dois aglomerados populacionais seria tanto mais curto quanto menos obstáculos (ríos, montes, etc.) o terreno oferecesse.

São, pois, muito estreitas as relações entre a geografia, a rede viária e o povoamento. Aspectos geográficos, como sejam o relevo, a rede hidrográfica, a fertilidade dos solos e a existência de matérias-primas, determinam a localização das comunidades agrárias, das indústrias de extracção de matérias-primas e das cidades bem como a configuração dos caminhos. Os aspectos políticos e económicos do povoamento ajudam também a configurar a rede viária. A rede viária, por sua vez, acaba por promover a fixação de populações em regiões que, inicialmente, seriam apenas regiões de passagem.

Dentro deste quadro de correlações entre geografia, povoamento e rede viária interessa, para o assunto deste artigo, focar o papel da rede viária como pólo de atracção para a fixação de novas populações. $\mathrm{Na}$ verdade, os viajantes sempre precisaram de estruturas de apoio, que lhes pudessem dar comida, dormida, muda de cavalo, etc. Portanto, a necessidade de apoiar os viajantes leva à fixação de populações ao longo das estradas. Por outro lado, a pressão populacional leva à disseminação do povoamento por áreas anteriormente desabitadas. Ribeiro (1971) chamava a este fenómeno dispersão intercalar. Naturalmente, essa disseminação das populações pelos espaços vazios processa-se primordialmente através da rede viária existente. Como também é através dessa rede viária que se escoam os bens excedentários, é junto a ela que as novas populações acabam por se fixar, desde que haja espaço e terrenos férteis para cultivar.

Muitos exemplos haverá do que acabo de dizer. Um deles veio de Freixo de Numão. Durante a elaboração da carta arqueológica desta freguesia, a reconstituição da rede viária romana deu pistas para a posterior descoberta de vilas e casais, por vezes em zonas de mata fechada, onde os achados ocasionais são mais difíceis (Corxão, 1997, p. 81).

É com este tipo de enquadramento que se irá abordar o problema de reconstituir o traçado dos segmentos da estrada romana compreendidos entre Emínio e Cale. Por um lado, raciocinando de causas para efeitos, conjectura-se qual seria o melhor traçado, dadas as condições geomorfológicas da região na época romana. Por outro lado, raciocinando de efeitos para causas, analisa-se a distribuição geográfica dos 
centros de povoamento intercalar mais antigos e, com base nessa distribuição, conjectura-se o traçado da estrada que melhor teria contribuído para a génese desses centros de povoamento antigo. Como se verá, a solução para o problema emerge naturalmente destes raciocínios.

\section{A evolução geomorfológica do Baixo Vouga}

A ria de Aveiro, uma laguna que se prolonga de Ovar até Mira, é um dos principais factores aglutinadores do distrito de Aveiro. No entanto, a ria é um acidente geográfico surpreendentemente recente. Inicialmente, quando o oceano Atlântico estabilizou em níveis próximos dos actuais (cerca do ano 1000 a. c., segundo Alveirinho Dias et 1997), a configuração do litoral entre Espinho e o Cabo Mondego apresentava uma pronunciada reentrância. Avançando de norte para sul, um cordão de areias viria a rectificar a linha do litoral, ao mesmo tempo que, no interior, se formava a laguna. Este processo ficou concluído em meados do século XVIII. A generalidade dos autores concorda actualmente que a formação do cordão litoral se terá iniciado por volta do século X (Castelo Branco, 1971; Mendes, 1974; Ferreira, 1993, p. 39-42; Brás Teixeira, 1994).

A configuração original do litoral aveirense apresentava, para além da concavidade referida, uma outra particularidade: entre Cacia e Angeja irrompia um braço de mar, que se prolongava até próximo de Ferméntelos. Aí confluíam o rio Vouga, bem conhecido dos escritores clássicos, e, ainda, os rios Águeda e Cértima. O progressivo assoreamento do braço marítimo levaria ao recuo da foz do Vouga.

O principal problema que se coloca é o de saber até que ponto o referido braço marinho penetraria no interior durante a dominação romana. Para solucionar este problema há que estudar uma série de fenómenos geomorfológicos, que vão desde o assoreamento provocado pelos rios da região até à própria tectónica.

Em rios com o caudal do Vouga, do Águeda ou do vizinho Mondego, a acumulação sedimentar pode fazer subir as cotas das margens vários metros em escassas centenas de anos. O ritmo de assoreamento do Mondego entre os séculos XIV e XIX já foi estimado em $1 \mathrm{~m} / \mathrm{século}$ (Seabra Lopes, 1995, p. 336, n. 30) ou 0,8 m / século (Loureiro, 1874, p. 90-94).

Conimbriga, 39 (2000) 191-258 
Na região do Vouga, algo de similar ocorreu. A própria delimitação da ria de Aveiro se fez, em boa parte, à custa dos sedimentos trazidos pelo rio. Na zona da ponte medieval do Vouga, o assoreamento pode ser medido com algum rigor. A primeira ponte sobre o Vouga de que há memoria foi construida ao longo da segunda metade do século XIII (Sousa Baptista, 1947; 1958).

No vizinho rio Marnel existiu também uma ponte desde a Idade Média. Encontrei recentemente a confirmação desse facto num documento de 1327: "monte maninho que eu ei en Riba de Vouga ... o qual monte parte polia carreira que uai da Mourisca pera a ponte noua de Marnel» (Chancelaria 1325-1336, doc. 131). Resta saber se lhe chamavam ponte noua por ter havido outra antes no mesmo local, ou apenas por ter sido construída depois da do Vouga.

$\mathrm{O}$ antigo selo da Terra de Vouga, cujo único exemplar conhecido pende de um documento de 1310, tinha como figura central uma ponte (Figura 1). Este exemplar, que encontrei graças a uma sugestão de José Mattoso, está descrito por LANCASTRE E TÁVORA (1983, n. ${ }^{\circ}$ 333). Trata-se de uma ponte de cinco arcos com pilares altos no centro. A ponte velha do Mamei tem precisamente cinco arcos (Figura 6). No entanto, dada a importância da travessia do Vouga, parece-me mais provável que a ponte representada no selo seja a do Vouga. Se a imagem do selo teve alguma relação com a realidade, então o leito do rio seria estreito e fundo.

Entretanto, sabe-se, por um documento de 1552 , que no reinado de Dom João III se realizaram obras importantes nesta ponte. Na realidade, deve ter sido construída uma nova ponte nessa altura, pois, segundo nogueira gonçalves $(1959$, p. 24-25), as numerosas siglas de canteiros que se podem observar na parte norte da ponte pertencem ao alfabeto gótico final. Passado século e meio, a ponte quinhentista já não cumpria o seu papel. Com efeito, segundo Carvalho da Costa, no início do século XVIII, a ponte do Vouga estava «tam areada, que em tempo de cheas se passa em barcos». Por essa época, Dom João $\mathrm{V}$ construiu uma nova ponte, de doze arcos, que ficou concluída em 1713. Aparentemente, da ponte quinhentista foram aproveitados apenas os arcos pequenos da parte norte. Em finais do século XVIII, provavelmente no Verão de 1776, foram acrescentados mais três arcos no extremo sul da ponte. De então para cá, não sofreu mais alterações de vulto (Figura 5).

As fotografias de nogueira gonçalves (1959, estampa 49) mostram-nos o grau de assoreamento do rio na década de 1950 (reproduz- 
-se uma delas na Figura 2). Não admira, pois, que tanto Nogueira gonçalves como sousa Baptista não tenham notado vestígios da ponte medieval. Porém, de 1959 para cá o leito do rio desceu cerca de 3,5 m. Suponho que tal só poderá explicar-se pela extracção de areias para a construção civil e/ou pela realização de trabalhos de dragagem e regularização do leito. O certo é que, graças a esse afundamento do leito do rio, estão hoje bem visíveis em seis pilares os arranques dos $\operatorname{arcos}$ da ponte medieval (Figura 6). Mantas (1996, p. 816-817), se notou este facto, não o referiu explicitamente.

Assumindo que a altura dos pilares da ponte medieval, desde a base até ao arranque dos arcos, era o normal, uns $2,5 \mathrm{~m}$, então as bases dos pilares da ponte medieval estarão pelo menos uns $6 \mathrm{~m}$ abaixo do nível atingido pelo leito do rio em 1960. Daqui resulta que o assoreamento do Vouga desde o século XIII andou próximo de $0,9 \mathrm{~m} /$ século, valor equivalente ao calculado para o Mondego.

Este ritmo de assoreamento torna verosímil a hipótese de o mar chegar até à ponte do Vouga na época romana, pois as cotas da várzea não excedem os $12 \mathrm{~m}$.

Sobre o assoreamento ocorrido no curso terminal do Vouga, a jusante da foz do Águeda, dispomos de dois importantes testemunhos. Por um lado, dois documentos relativos a Rexico (Fermelã), um de 1182 e outro do ano seguinte, situam inequivocamente nessa zona a entrada do Vouga no mar: "secus litus maris in oceani et ostium quo Vauga flumen intrat in mare» (OLIverRa, 1967, p. 60). Este testemunho está em perfeito acordo com o facto de não existir ainda nesta época a ria de Aveiro. Por outro lado, Edrizi, também no século XII, afirmou que a maré subia muitas milhas pelo Vouga acima: «o Vouga é um rio grande, no qual entram embarcações de comércio e galés, porque a maré sobe muitas milhas por ele acima» (tradução de D. Lopes, 1911, p. 81-87). Portanto, facilmente se imagina que o curso terminal do Vouga estaria ao nível do mar no século XII. Actualmente, as cotas das margens do Vouga nessa zona andam numa média de $3,5 \mathrm{~m}$. Portanto, o assoreamento médio desde o século XII terá sido pelo menos $0,4 \mathrm{~m} /$ século. É compreensível que o assoreamento na zona da ponte do Vouga tenha sido maior porque a várzea é aí muito mais estreita.

$\mathrm{O}$ rio Águeda é também muito caudaloso. A primeira ponte sobre este rio, que deu lugar à formação do burgo ou aldeia de Águeda, foi construída no século XIII, como a do Vouga. No entanto, em 1614 foi construída uma nova ponte (Figura 5). Passados apenas dois séculos, 
em 1835, a ponte já não satisfazia as necessidades do trânsito, em especial no tempo das cheias, e colocava-se a hipótese da construção de uma ponte alternativa em Assequins (Teodoro de Matos, 1980, p. 537). Finalmente, em 1873, a ponte filipina estava «meio soterrada» (Ramos, 1988, p. 67) e foi considerada invadiável, pelo que se construiu uma ponte provisória em madeira e se iniciaram diligências com vista à construção de uma nova ponte. O tabuleiro da nova ponte, construída alguns anos depois, ficou cerca de 3,5 $\mathrm{m}$ acima do tabuleiro da ponte filipina.

A Figura 5 mostra o rio com caudal normal. Vêem-se as areias da margem e nelas roupa a secar ou corar, ao fundo de uma escadinha. Assim, de acordo com a figura, na segunda metade do século XIX as águas corriam normalmente ao nível dos arranques dos arcos. Um limite mínimo credível para o assoreamento registado desde 1614 será de $1,5 \mathrm{~m}$, ou seja, cerca de $0,6 \mathrm{~m} /$ século.

Outro tradicional ponto de passagem do rio Agueda situa-se entre Almear e Eirol. Em 1377, já ali existia uma ponte (Sousa Baptista, 1959). Em 1616, foi, ao que parece, construída uma nova. Um estudo setecentista sobre a barra de Aveiro e a navegação do rio Vouga dá informações importantes sobre o estado da ponte de Almear e sobre o assoreamento do rio Águeda nesta zona (Pereira \& Ramos, 1778ab). Esta ponte não era toda de arcos, mas nem por isso deixava de ser monumental, pois o seu comprimento total era de 3000 palmos ou 660 $\mathrm{m}$ (este comprimento corresponde à largura da várzea). Em 1778, tinha quatro arcos caídos e a travessia fazia-se de barco. Segundo os autores do estudo, o assoreamento na zona terminal do Vouga era tal que, no tempo das cheias, as águas subiam pelo Águeda acima, assoreando este rio "de sorte que a ponte está muito baixa e as xêas lhe quebram as cortinas, e lhe tem feito muitos rombos, depois de lhe ter deitado os arcos abaixo». Em 1865-66, foi demolido o que restava da ponte de Almear e construída uma nova.

As pateiras do Marnel e de Ferméntelos ambas se explicam pelo mesmo princípio: o assoreamento provocado por um rio caudaloso faz subir as cotas do seu leito e das suas margens e acaba por barrar a passagem a um afluente, cujo ritmo de assoreamento é menor. A pateira do Marnel (Figura 6) foi drenada, mas as cotas do terreno, na confluência deste pequeno rio com o grande Vouga, ilustram bem o que acabei de dizer: a jusante da confluência, as cotas das margens do Vouga andam em torno dos $12 \mathrm{~m}$; no entanto, nas margens do rio Mar- 
nel, a montante da ponte sobre este rio, as cotas chegam a ser apenas de $7 \mathrm{~m}$ (portanto, $5 \mathrm{~m}$ abaixo) ${ }^{l}$.

A formação da pateira de Ferméntelos tem origem similar. Neste caso, o rio Águeda, quase tão caudaloso quanto o Vouga, foi subindo o nível das suas margens a um ritmo superior ao do seu afluente Cértima, acabando por lhe barrar a passagem. A formação da pateira de Ferméntelos é muito recente. Na Idade Média, grande parte do espaço em volta do rio Cértima e compreendido entre Óis da Ribeira, Perrães e Paradela era terreno seco, coberto de mata e coutado para caça.

Em finais do século XV, já ali existia um paul. Note-se, porém, que paul significa principalmente brejo, terra encharcada ou alagadiça. Em 1672, estando a mata «apaulada», certas medições tiveram que ser feitas de barco (Morais, 1922). Poucos anos depois, o Santuário Mariano volta a referir a existência do paul (SANta Maria, 1721, p. 453-457). A presença de grandes quantidades de água era ainda um fenómeno temporário, pois, segundo o Santuário Mariano, o paul permitia a passagem, excepto quando estava cheio: «quando o paul está cheio e se não pode passar...». Significativamente, as numerosas corografias e respostas a inquéritos escritas no século XVIII não aludem a nenhum lago ou pateira nesta zona (Silveira, 1914). No já citado estudo sobre a barra e navegação do Vouga também não se encontra qualquer referência a um lago ou pateira no curso final do Cértima (Pereira \& Ramos, 1778ab). Uma memória sobre o mesmo assunto apresentada à Academia das Ciências em 1820 refere que «no Inverno se forma um grande lago» junto ao lugar de Requeixo (Baptista, 1829), sinal de que não existia ou era de formação recente o grande lago permanente que hoje conhecemos.

Finalmente, passadas mais duas décadas, surge a primeira referência à pateira, sendo as dimensões indicadas próximas das actuais (Um Flaviense, 1839). Os terrenos cobertos pelas águas em épocas relativamente recentes mantiveram-se na posse de particulares. No princípio do século $\mathrm{XX}, 1 / 3$ de toda a pateira era propriedade particular (Рато, 1919, p. 12).

A profundidade máxima da pateira de Ferméntelos era em 1919 (mês de Março) de 2,6 m (PАто, 1919, p. lie 27), embora a maior parte do relevo se encontrasse a profundidades compreendidas entre 1 e 1,6 m

${ }^{1}$ Ver a carta de 1:10000 desta zona, fornecida pela Câmara Municipal de Águeda. Alternativamente, ver o mapa publicado em SEABRA LOPES, 1995, figura 1. 
\{idem, mapa anexo). Como, ao que tudo indica, o processo de formação da pateira se desenrolou essencialmente a partir do século XVI, podemos supor que a várzea do rio Águeda se elevou a um ritmo próximo de $0,4 \mathrm{~m} /$ século, pouco menos de metade do que se registou no Mondego e na ponte do Vouga. Esse ritmo poderá mesmo ter sido superior, pois o próprio fundo da pateira se foi elevando \{idem, p. 22, n. 1).

Tabela I - Ritmos de assoreamento no rios Mondego, Vouga e Agueda

\begin{tabular}{lc}
\hline Rio elocal & $\begin{array}{c}\text { Ritmo de assoreamento } \\
\text { (metros / século) }\end{array}$ \\
\hline Mondego - de Coimbra até à foz & 0,8 a 1,0 \\
Vouga - zona da ponte medieval & 0,9 \\
Vouga - a jusante da foz do Agueda & $>0,4$ \\
Águeda - zona da ponte da cidade de Águeda & $>0,6$ \\
Águeda - zona da foz do Cértima & 0,4 \\
\hline
\end{tabular}

As cotas da várzea do Águeda variam entre os $5 \mathrm{~m}$ junto a Óis da Ribeira, povoação sobranceira ao antigo braço marinho, e os $11 \mathrm{~m}$ junto a Assequins, dando uma média de $8 \mathrm{~m}$. Admitindo que o ritmo de assoreamento também aqui se aproximou de 0,4 a 0,6 m / século, então facilmente se aceitará que, na época romana, parte da várzea do Águeda possa ter estado ao nível do mar ou, pelo menos, sujeita à acção das marés.

A Tabela I apresenta um sumário dos ritmos de assoreamento acima calculados. Que eu saiba, esta é a primeira tentativa de medir o assoreamento nos principais rios da região nos últimos 1000 anos.

A hipótese da presença do mar nas proximidades do Marnel e de Ferméntelos na época romana já foi admitida ou mesmo defendida por outros autores, entre os quais AMORIM GIRÃO. Este autor refere, por exemplo, que sondagens realizadas por $\mathrm{R}$ Choffat nos aluviões de Macinhata, já a montante do Marnel, permitiram encontrar restos de peixes e moluscos marinhos do Quaternário tardio (AMORIM GIRÃO, 1922, p. 55). Parece também que, muitas vezes, quando se arranca moliço na pateira de Ferméntelos, surgem conchas marinhas e areia lavada (МотA, 1991, p. 137). Conchas marinhas e búzios têm ainda aparecido em zonas próximas da pateira. É claro que parte disto poderá explicar-se pela presença do mar numa época interglaciar em que 
o nivel do mar tenha sido superior ao actual. Nesse caso, nenhuma conclusão pode tirar-se quanto à posição relativa do mar na época romana, que é o que mais importa para este artigo.

Depois de subir cerca de $120 \mathrm{~m}$ desde a última glaciação, o mar na costa portuguesa estabilizou em níveis próximos dos actuáis por volta de 1000 a. C. (Alveirinho Díss, 1987). Nada nos garante, porém, que a crosta terrestre tenha estado imóvel. O geólogo alemão Lautensach colocou, em tempos, a hipótese de que o chamado Eixo de Culmimição Ibérica Principal teria vindo a empolar-se ao longo do Quaternário, arrastando consigo o noroeste de Portugal (Ribeiro, Lautensach \& Daveau, 1987, p. 144-145, 161, 207-208). Tal hipótese, que ainda não foi abandonada, é especialmente sugerida por uma anormal inclinação dos terraços dos vales do Minho, Lima e Vouga.

$O$ estudo recente de uma arriba em Cortegaça, no extremo norte do distrito de Aveiro, revelou que nessa zona se registou uma elevação tectónica média de $0,25 \mathrm{~m} /$ século ao longo dos últimos 6000 anos (Granja \& DE Groot, 1996). Obviamente, isto não é generalizável ao Marnel, à várzea do Águeda ou à pateira de Ferméntelos. No entanto, este facto mostra que fenómenos de elevação tectónica têm-se prolongado até ao presente. Se, por hipótese, o ritmo de elevação tectónica no Baixo Vouga foi similar ao de Cortegaça, então, na época romana, esta região estaria $5 \mathrm{~m}$ mais abaixo.

O que foi apresentado são apenas alguns elementos para uma discussão que carece ainda de muita investigação no domínio das Ciências da Terra. No entanto, do que fica dito resulta no mínimo verosímil que, na época romana, a várzea do Águeda e as zonas de Ferméntelos e do Mamei estivessem sob influência marinha. Os elementos recolhidos dão também particular consistência à afirmação categórica de Edrizi (séc. XII), já citada, segundo a qual o mar subia muitas milhas pelo Vouga acima. No resto do artigo ver-se-á que a evolução da rede viária e do povoamento do Baixo Vouga reflecte também a evolução geomorfológica que acabei de reconstituir. Caso tenha sido outra a evolução geomorfológica da região, muitos factos históricos deixam de fazer sentido.

\section{A estrada romana e alguns itinerários alternativos}

O segmento mais controverso da estrada romana Emínio-Cale é, sem dúvida, o que ficava compreendido entre Emínio e Talábriga. Tal

Conirnbriga, 39 (2000) 191-258 
facto fica a dever-se à complexidade da rede hidrográfica da região. Começarei por investigar os itinerários sugeridos pelas condições geográficas, a que poderemos chamar itinerários naturais ou itinerários ancestrais. Depois apresentarei sucintamente os itinerários medievais de ligação de Coimbra ao Marnel. Finalmente, darei uma breve descrição do traçado da estrada Emínio-Cale que considero mais provável. Esse traçado será pormenorizadamente apresentado na secção 9 .

Os velhos Lusitanos, quando viajavam em direcção ao Noroeste peninsular, pela faixa litoral, tinham nos rios o principal obstáculo a vencer. Encontravam primeiro o Mondego que só poderiam passar facilmente no local onde se desenvolveu a cidade de Emínio, ou a montante desse ponto. Encontravam depois o rio Cértima que não lhes oferecia grande obstáculo. O Vouga cruzava-se com máxima vantagem nas imediações do Marnel.

E a várzea do Águeda seria fácil de passar? Como referi, por razões ligadas à tectónica, é possível que toda esta região estivesse bastante mais baixa na época romana. Esse facto, a confirmar-se, só por si justificaria a presença do mar em grande parte da várzea do Águeda. Mas mesmo se considerarmos que a crosta esteve estável, temos ainda a favor dessa hipótese o elevado ritmo de assoreamento do rio (pelo menos $0,4 \mathrm{~m} /$ século, segundo os cálculos que apresentei). A travessia do Águeda foi um problema difícil de resolver até épocas bem recentes. Em 1835, estudava-se a possibilidade de construir uma nova ponte, não entre o Sardão e a vila de Águeda, mas sim entre a Borralha e Assequins (Tеodoro de мatos, 1980, p. 537). O objectivo era evitar as cheias que invadiam a várzea, as quais, por vezes, demoravam uma semana a desaparecer, deixando os viajantes bloqueados ou obrigando-os a passar em barcos.

Assim, sem entrar em mais conjecturas, por agora difíceis de confirmar, parece-me verosímil supor que a travessia do Águeda, onde hoje passa a estrada nacional, terá sido difícil, na época romana. Daqui resulta que os viajantes se afastavam do centro da várzea e faziam a travessia em Óis ou em Assequins, que são os pontos mais favoráveis.

Esta ideia é, aliás, apoiada pela seguinte observação de Амовıм Girão (1922, p. 130): «É tão sensível a acção das influências geográficas que duas leis gerais se podem estabelecer sobre a distribuição e o estado de conservação das estradas: as do interior seguem de preferência os vales enquanto as do litoral os evitam quanto possível». 
O vale do Cértima não constitui um grande obstáculo ao tránsito, mas, ainda assim, apresenta um série de pequenos obstáculos (Silveira, 1914). Se o viajante, indo de sul para norte, preferisse seguir pela margem direita, teria que cruzar o próprio Cértima na zona de Viadores e, depois, uma série de afluentes: o ribeiro da Vacariça, o ribeiro do Peneireiro, o rio de Arcos, o rio de Avelãs, o ribeiro de Aguadela e o rio de Aguada. Se o viajante optasse por seguir pela margem esquerda do Cértima, teria que cruzar apenas três pequenos afluentes (os ribeiros de Ventosa, de Horta e de São Lourenço) e depois cruzaria o próprio Cértima entre Sangalhos e Barro. Em qualquer dos casos, quanto mais o viajante se afastasse do curso do Cértima, mais facilmente cruzaria os afluentes.

Assim, a rede hidrográfica do Baixo Vouga define essencialmente dois tipos de itinerários de ligação entre a passagem do Mondego, junto a Coimbra, e a passagem do Vouga, junto ao Marnel:

- Itinerário ocidental - o viajante seguia pela margem esquerda do Cértima, por Vimieira, Ventosa, Horta, Mogofores e Sangalhos, cruzava o rio Cértima na direcção de Barro, continuava por Paradela, Espinhei e Ois da Ribeira, onde cruzava o Águeda no extremo ocidental da sua várzea, e finalmente seguia por Travassô e Segadães até ao Marnel.

- Itinerário interior - neste caso, o viajante seguia pela margem direita do Cértima, passando sucessivamente pela Mealhada, Aguim, Anadia, Aguada de Cima e Borralha, cruzava o rio Águeda em direcção a Assequis, e depois continuava por Aguieira, Valongo e Fundo da Rua até alcançar o Marnel.

Quando mais se recua no tempo, maior é a probabilidade de serem estes os itinerários de facto utilizados. Por isso também lhes chamo os itinerários ancestrais da região. A antiguidade destes itinerários é confirmada pela grande concentração de povoamento antigo ao longo do seu traçado, em contraste flagrante com a quase total ausência de povoamento antigo ao longo da actual estrada nacional (ver secções 5-7).

O progressivo assoreamento da várzea do Águeda viria a proporcionar o surgimento de dois novos itinerários, que seguiam uma directriz mais rectilínea e se documentam a partir do período da Reconquista Cristã: 
- estrada mourisca - decalcava o acima referido itinerário ocidental até Barró e, a partir deste ponto, seguia directamente para Recardães e cruzava o rio Águeda no centro da sua várzea, em frente a Paredes.

- estrada coimbrã - quase coincidente com a moderna estrada nacional N1; passava por Carquejo, Mealhada, Avelãs do Caminho, Aguada de Baixo e Águeda.

Num dos meus primeiros trabalhos sobre estes assuntos (SEABra Lopes, 1994b), fiz uma inventariação relativamente exaustiva das referências medievais a estradas entre Coimbra e Porto e, tendo em conta a toponímia e os vestígios materiais, procurei identificar o traçado da estrada mourisca bem como o traçado da mais recente estrada coimbrã.

A expressão estrada mourisca, que designava, no período da Reconquista Cristã, a estrada de ligação do Porto a Coimbra, tem intrigado bastante os investigadores, levando alguns a concluir que a referida estrada havia sido construída pelos Mouros. Penso que chamavam mourisca à estrada simplesmente porque levava à terra dos Mouros. Convém lembrar que a cidade de Coimbra só foi definitivamente integrada no domínio cristão em 1064. Portanto, a expressão estrada mourisca designava sempre uma estrada que se dirigia para sul. Estradas com orientação este-oeste não poderiam receber esta designação. Com o progresso da Reconquista e a elevação de Coimbra a capital do Reino, a estrada passou a chamar-se estrada coimbrã, porque levava a Coimbra. Esta designação parece que foi a mais comum entre os séculos XIII e XVII.

Curiosamente, em finais do século XII, quando o novo nome se preparava para entrar em cena, o próprio traçado da estrada, que passava na margem esquerda do Cértima, muda para a margem direita. Assim, nesta região as expressões estrada mourisca e estrada coimbrã acabam por designar traçados bastante diferentes. Este facto não tem sido notado pelos investigadores.

O investimento na rede viária durante a Idade Média foi bem maior do que por vezes se pensa. Sabemos que, em pleno período da Reconquista Cristã, no século $\mathrm{X}$, o mosteiro de Lorvão confiou ao mestre Zacarias, oriundo de Córdova, a construção de várias pontes (Nogueira Gonçalves, 1967). Dom Afonso Henriques iniciou a construção da ponte de Coimbra em 1132, a qual só veio a concluir-se em finais do 
século XIII. Pela mesma época estavam a ser concluídas as pontes do Vouga e do Águeda (SousA BAPTISTA, 1947; 1958).

A construção de novas estradas ou de traçados alternativos é, normalmente, mais difícil de documentar. Entre Coimbra e Porto há, todavia, um exemplo que não deve suscitar dúvidas (SEABRA Lopes, 1994b, p. 87). Em 1220, a estrada mourisca passava por Figueiredo, onde existia um paço de pernoita da familia real. Neste segmento do seu traçado, a estrada mourisca devia decalcar a romana, pois, em Ul, no mesmo alinhamento, apareceu um miliário. Em 1284, documenta-se o nascimento de uma nova povoação, a Bemposta, criada pouco tempo antes pelo almoxarife. E natural que a criação desta nova povoação se tenha ficado a dever à alteração do traçado da estrada, que, nesse caso, terá ocorrido por meados do século XIII. O próprio topónimo parece indicar que a nova povoação estava bem posta ou bem localizada, certamente em relação à estrada (outra Bemposta surgiu junto à estrada Coimbra-Aveiro). Esta alteração do traçado da estrada levou à transferência da sede do julgado de Figueiredo para a Bemposta bem como à transferência do paço real de Figueiredo para o lugar do Curvai.

Quanto à alteração do traçado da estrada mourisca entre o Marnel e Coimbra, vários são os documentos que a indicam claramente. Uma primeira indicação sobre a passagem da estrada mourisca na margem ocidental do Cértima é a designação que lhe era dada na zona de Coimbra até ao século XII: strada de Viminaria (DC 106; DC 741; LP 40; LP 174; SeAbra Lopes, 1994b, p. 102-103). De facto, a Vimieira é já uma povoação da margem ocidental do Cértima.

Dois documentos relativos à zona de Mogofores, que já miudamente analisei no artigo de 1994, são particularmente elucidativos. Um deles, de 1143, contém a demarcação de Ancas, vila situada a ocidente de Mogofores, que começa assim: "In oriente, quomodo diuidit cum Mogofores et cum Saa, per unum fontem de Lodeiro, quomodo uertit aquam, per illud suber forcatum et inde per illam stratam mauriscam ...» (DR 201). Significa este passo que, a oriente, Ancas confrontava com Mogofores e com Sá por uma linha que partia da fonte de Lanteiro (fontem de Lodeiro), que ainda existe junto ao lugar de São Mateus, descia a ribeira de Valbom \{uertit aquam), passava perto de um sobreiro $\left\{\right.$ suberforcatum $^{2}$ ) e seguia pela estrada mourisca.

\footnotetext{
${ }^{2}$ No artigo de 1994, interpretei a expressão forcatum como significando 'cruzamento' ou 'bifurcação'. Suber forcatum seria, pois, um cruzamento da estrada mourisca
} 
O caminho que actualmente liga o Cabeço de Mogofores ao Paraimo e a Sá, passando pelo sítio da Fonte Podre, parece corresponder à estrada mourisca que o documento refere. Do que não pode haver dúvida é que, em pleno século XII, a estrada mourisca passava na margem esquerda do Cértima e servia de fronteira entre as vilas de Ancas, de um lado, e Mogofores e Sá, do outro.

SAA (1960, p. 174-191), embora localizando correctamente a estrada mourisca na zona de fronteira entre Ancas e Mogofores, encaminhou o seu traçado em direcção a São João de Loure, hipótese que contraria tudo o que se sabe sobre a directriz da estrada de ligação entre o Porto e Coimbra na Idade Média (SEABra Lopes, 1994b, p. 97-100). De resto, no século XII, a travessia do Vouga em São João de Loure seria ainda muito difícil. Sousa BAPTISTA (1948) referiu-se ao documento de Ancas sem, no entanto, dar qualquer interpretação para a passagem da estrada mourisca na margem esquerda do Cértima. MANTAS (1996, p. 811) utiliza o documento para apoiar a sua ideia de que a estrada passava entre Mogofores e Famalicão. Ora, do documento deduz-se precisamente o contrário: a estrada passava a ocidente de Mogofores, entre Mogofores e Ancas.

No outro documento, do ano de 1226, demarca-se a vila de Mogofores. Nele se localiza claramente a estrada coimbrã, na margem direita do Cértima e a servir de fronteira entre Mogofores e Arcos. O mesmo documento refere urna estrada velha algures na zona de confrontação de Mogofores com Ancas, Sá e Sangalhos e não longe da Fonte Podre* 3. Sem dúvida, esta estrada velha só pode ser aquela a que o documento de 1143 chamava estrada mourisca, a qual também passava na Fonte Podre. Entre 1143 e 1226 teria, pois, sido realizada urna importante alteração do traçado da estrada.

Mais urna vez, MANTAS (1996, p. 811) faz passar esta estrada velha em Famalicão, que é coisa que de forma alguma se pode deduzir do documento de 1226. Num outro passo (p. 901), o autor baseia-se nos

com uma outra via, actualmente chamada caminho da igreja. Parece, todavia, que suber forcatum deve ser traduzido como 'sobreiro forcado', seja lá o que isso for.

${ }^{3}$ «per medium de Barrio de Ahito sub portela de Eneas quomodo vadit per valem ad infestam ad estratam veteram sub mamoa de escusa ad sumitatem de Valonga quomodo dividit cum Sá et cum Sangalios, et deinde quomodo vadit ad mamoam de Valle de Estephano sub mamoa de Fonte Putre» (Rodrigues, 1959, p. 187). Continuando o circuito da demarcação, o documento refere sucessivamente a Cortiçada, Famalicão, Arcos, estrada coimbrã, Canavai e Outeiro. 
mesmos documentos de Ancas e Mogofores para apoiar a hipótese da existência de urna via romana de ligação da zona de Mogofores a Cacia. A verdade é que a distribuição do povoamento antigo desta região não dá dessa hipotética via o mais leve indício.

Há ainda outra referência importante a uma estrada velha que se dirigia a Coimbra pela margem ocidental do Cértima. Trata-se da demarcação de umas propriedades em Ventosa do Bairro, realizada em 1288: «... uns herdamentos que jazem como parte de huma parte pela Mealhada Má, e da outra parte como parte pela estrada velha coimbram, e da outra parte como parte pela agoa de Certoma, e vai athe hu se junta a agoa de Ventoza com na de Certoma ...» (BRANQUINHO DE CARvalho, 1950). Esta estrada velha coimbrã deve ser a mesma que passava em Mogofores e tinha sido conhecida como estrada mourisca e depois também como estrada velha. Como se verá na secção 7, o principal alinhamento de povoamento antigo desta região passa precisamente em Mogofores e em Ventosa.

O traçado da estrada coimbrã entre o Marnel e Coimbra pela margem direita do Cértima não foi, no entanto, criado de raiz. Documentos anteriores ao século XIII (só conheço três: DC 73; DP/III 17; DR 179) referem a existência de estradas cujo traçado coincide com o da estrada coimbrã. No entanto, seriam ainda estradas secundárias. A maior importância da estrada da margem esquerda no século XII evidencia-se pela adjectivação de estrada velha que lhe é dada no século XIII. O carácter secundário, até ao século XII, da estrada da margem direita evidencia-se pela quase total ausência de povoamento antigo ao longo do seu traçado.

Identificam-se, pois, quatro grandes itinerários entre Coimbra e o Marnel. Dois deles, que designei por intinerário interior e itinerário ocidental, são antiquíssimos. Ao longo do seu traçado se encontram as povoações mais antigas da região. No entanto, é, em especial, sobre o traçado do itinerário ocidental que se encontram as povoações com mais pergaminhos históricos bem como a maior densidade de vestígios da romanização (ver secções 5-7). Estou convencido de que o itinerário ocidental era o mais utilizado na época romana. A estrada mourisca é uma linearização do itinerário ocidental. A estrada coimbrã fez emergir uma série de povoações novas, muitas delas hoje dominantes, e remeteu para a obscuridade povoações com bem mais preclaras origens.

$\mathrm{Na}$ secção 9 apresentarei em mais pormenor o traçado da estrada romana que me parece mais provável. Por agora, apresento-o apenas nas 
suas linhas gerais. O ponto de partida é a ponte de Coimbra, que tomo como referência de Emínio. Passando sucessivamente por Pedrulha, Adémia, Cioga, Treixomil, Sargento Mor e Carquejo, a estrada romana atingia a Vimieira, na margem ocidental do Cértima. Daqui até à ponte do Mamel, que é a minha referência de Talábriga, o itinerário seguido seria o itinerário ocidental acima descrito. Para norte, a estrada cruzaría o Vouga provavelmente no local da ponte medieval, continuaria depois por Assilhó, Figueiredo, Ul, Oliveira de Azeméis, Lações de Baixo, São João da Madeira, Arrifana, Fiães (= Lancóbriga), Serzedelo, Argoncilhe e Carvalhos, alcançando finalmente Vila Nova de Gaia. O local da travessia do Douro é a referência que adopto para Cale.

Até aqui, a maior parte dos autores tem considerado a estrada coimbrã como sendo a própria estrada romana, à parte pequenos desvios que pudessem ter ocorrido (Oliveira, 1943; Nogueira GonÇALvES, 1959; 1967; 1981; CASTRO, 1987; MANTAS, 1996).

A ideia de que a rede hidrográfica da região colocaria problemas à circulação e daria origem a dois itinerários alternativos, um que a contornava pelo interior e outro mais pelo litoral já foi apresentada por SAA (1960, p. 107-110). Aliás, o itinerário interior a que me referi acima coincide em grande parte com a chamada estrada romana de leste ou estrada do cosmógrafo, proposta por SAA (1960, p. 110-124). Como variante ocidental da estrada do cosmógrafo, o autor propôs uma outra estrada, denominada estrada romana da Feira, a qual seguia pela margem direita do Cértima e cruzava o Vouga em São João de Loure (SAA, 1960, p. 174-191). O meu itinerário ocidental é parecido com esta estrada da Feira na parte compreendida entre Coimbra e Mogofores. Dadas as condições geográficas da região até à Idade Média, o cruzamento de uma estrada com o Vouga na área de São João de Loure parece-me completamente inverosímil na época romana. De resto, a maior parte dos vestígios em que o autor se apoiou devem pertencer a uma outra estrada que ligava a Beira a Aveiro, passando por Avelãs do Caminho (Seabra Lopes, 1994b, p. 97-100).

SOUSA BAPTISTA (1948) apresentou uma proposta de traçado para a parte da estrada romana compreendida nos limites do actual concelho de Águeda que também diverge do traçado da estrada coimbrã. $\mathrm{O}$ autor foi o primeiro a admitir a passagem da estrada em Mogofores. Daqui para norte a estrada seguiria por Avelãs do Caminho, Aguada de Baixo, Barró, Recardães, Paredes, Crastovães, Covelas e Lamas, cruzando o Vouga aproximadamente no local da ponte medieval. Num artigo 
posterior, o autor chegou a admitir o desvio da estrada por Paradela, entre Barro e Recardães (Sousa Baptista, 1958). A base principal de Sousa Baptista é o levantamento que fez das referências medievais a estradas e, além disso, a toponímia. Ladeira (1982, I, p. 153 e 258) reproduz as propostas de Sousa Baptista. Nenhum destes autores se deu ao trabalho de medir as distâncias, de estudar o povoamento ou de relacionar o traçado proposto com as condições geográficas. São, pois, propostas feitas um bocado no ar, pouco passando de sugestões.

Em todo o caso, o traçado proposto por sousa Baptista e também defendido por Ladeira tem algumas semelhanças com o traçado que proponho. As diferenças principais são duas: eu faço a estrada romana continuar de Mogofores até Sangalhos, só aí se fazendo a travessia do Cértima, enquanto Sousa Baptista sugere a travessia do Cértima entre Mogofores e Avelãs; além disso, eu defendo que a travessia do Águeda se faria normalmente em Óis da Ribeira e não em Recardães. De resto, passando a estrada em Barro, como sugeriu Sousa Baptista, pouco sentido faria o desvio para poente até Paradela, para depois voltar a desviá-la para nascente em direcção a Recardães. Na verdade, para quem está em Paradela, o ponto natural de travessia do Águeda é em Óis.

A tabela II apresenta as distâncias entre Emínio e Talábriga e entre Talábriga e Cale por vários itinerários. A distância entre Talábriga e Cale pelo traçado da estrada real foi obtido da Carta Itinerária de Portugal, edição de 1905 (Seabra Lopes, 1995, p. 334, n. 17). As restantes distâncias itinerárias foram medidas sobre cartas militares da região à escala 1:25000. Excepção feita à estrada coimbrã e à estrada real de 1905, cujos traçados são bem conhecidos, os outros itinerários foram reconstituídos, sempre que possível, com base nos caminhos existentes. As distâncias foram medidas ao longo desses caminhos.

A tabela II apresenta ainda as taxas de encurvamento correspondentes a cada itinerário. A noção de encurvamento foi por mim introduzida em publicações anteriores (SEABra Lopes, 1996c; 1997ab): a taxa de encurvamento relativa a um certo itinerário é a diferença entre a distância itinerária e a distância em linha recta em proporção da distância em linha recta. Assim, por exemplo, sendo de 78,3 milhas a distância Coimbra-Gaia pela antiga estrada real, e sendo de 70,5 milhas a distância em linha recta, a taxa de encurvamento vem a ser (78,3$-70,5) / 70,5-11,1 \%$.

Dos quatro itinerários alternativos que considerei para a ligação entre Emínio e Talábriga, aquele que julgo ter sido preferido pelos

Conimbriga, 39 (2000) 191-258 
Romanos, pelas razões já apontadas, é precisamente o mais longo e, portanto, o de maior encurvamento ${ }^{4}$. O itinerário interior terá sido sempre uma boa alternativa, pois também evitava o centro da várzea do Águeda e tinha já um encurvamento mais aceitável. Todavia, o itinerário ocidental tinha a importante vantagem de tocar a linha do antigo litoral. Mais precisamente, o itinerário ocidental tocava o braço marinho que, até época recente, atingia a zona de confluência dos rios Vouga, Águeda e Cértima. Portanto, o itinerário ocidental permitiria o contacto directo com as rotas marítimas. Esta zona de confluência dos três rios manteve-se como principal foco de povoamento da região até à Alta Idade Média. Certo é que a distância Emínio-Talábriga pelo itinerário ocidental se arredonda para as 40 milhas que o Itinerário de Antonino indica.

TABela II - Distâncias pelos itinerários considerados e encurvamentos correspondentes

\begin{tabular}{lcc}
\hline Estrada ou itinerário & $\begin{array}{c}\text { Distância por } \\
\text { estrada (em milhas) }\end{array}$ & $\begin{array}{c}\text { Encurvamento } \\
(\%)\end{array}$ \\
\hline Emínio-Talábriga (31,8 milhas em linha recta) & & \\
$\quad$ Itinerário ocidental ou romano & 39,6 & 24,5 \\
$\quad$ Estrada mourisca & 37,0 & 16,4 \\
$\quad$ Itinerário interior & 36,5 & 14,8 \\
$\quad$ Estrada coimbrã & 34,5 & 8,5 \\
Talábriga-Cale (38,5 milhas em linha recta) & & \\
$\quad$ Estrada romana & 42,9 & 11,5 \\
$\quad$ Estrada real em 1905 & 43,1 & 12,0 \\
\hline
\end{tabular}

A preferência pelo litoral está bem patente no traçado da mais antiga estrada de ligação do Noroeste peninsular à foz do Tejo e, em especial, a Olisipo. Foi, aliás, seguindo este velho itinerário que Plínio descreveu o litoral da Lusitânia. A estrada cruzava o rio Douro quase na foz deste rio, junto a Cale. Em seguida, à medida que ia atravessando os territórios dos Túrdulos Velhos e dos Pesures, a estrada desviava-se

4 A grande taxa de encurvamento deste itinerário deve-se ao desvio imposto pela travessia do Águeda entre Óis da Ribeira e Travassô. A parte maior do trajecto, compreendida entre Coimbra e Travassô (34,5 milhas pelo itinerário e 29,5 milhas em linha recta), tem um encurvamento normal (16,9\%). 
para o interior por forma a atingir o Vouga no seu melhor ponto de passagem, na zona do Marnel. Aqui ficava Talábriga. Em seguida, dos dois melhores pontos de passagem do Águeda seria geralmente preferido o de Óis da Ribeira, que ficava junto ao braço marinho. Logo a sul, outro rio importante, o Mondego, impedia a aproximação ao oceano. A estrada continuava, pois, pelo interior até à moderna Coimbra, então chamada Emínio. Daqui para sul, a estrada voltava a aproximar-se do litoral, seguindo por Condeixa-a-Velha, São Sebastião do Freixo (Batalha), Óbidos e Torres Vedras até Lisboa (Mantas, 1996, p. 691-721 e 853-875).

Nas três secções seguintes investigarei as relações entre as sucessivas alterações de traçado da estrada de ligação Emíno-Cale ou Coimbra-Porto e a evolução da estrutura do povoamento da região de entre Douro e Mondego.

\section{Vestígios da rede viária na estrutura do povoamento antigo da região do Vouga}

O estudo da distribuição do povoamento antigo dá também indicações claras sobre a rede viária. A inventariação de todas as povoações referenciadas na documentação mais antiga, por exemplo até ao século XII, certamente nos daria uma espécie de radiografia da rede viária que existia antes da criação da estrada mourisca. Essa inventariação permitiria, por exemplo, distinguir, através da concentração do povoamento, as vias principais das vias secundárias. No entanto, uma tal inventariação envolveria a consulta de uma enorme massa de documentação, parte significativa da qual ainda nem sequer está publicada. Na secção 6 farei a inventariação das povoações situadas ao longo de certos itinerários previamente seleccionados e referidas até ao século XII. No que se segue, basear-me-ei exclusivamente nas listas medievais das igrejas e das cavalarias da terra de Vouga para inferir os principais itinerários desta região. $\mathrm{Na}$ Figura 7 , apresenta-se um esboço topográfico das cavalarias e das igrejas existentes nesta região por volta de 1300.

As cavalarias eram casais que conferiam aos seus possuidores a obrigação de participar nos saques que anualmente se empreendiam pelo território muçulmano. O cavaleiro levava à sua custa para estas expedições cavalo, escudo e lança. Os possuidores das cavalarias eram, 
no mínimo, cavaleiros vilões, portanto membros da elite do mundo rural e, em particular, das famílias mais antigas de cada terra ou região. Sousa BAPTISTA (1959) situa a origem destes casais de cavalaria no século XI. O estudo da distribuição geográfica das cavalarias dá-nos, pois, indicações importantes sobre o povoamento antigo. As povoações da terra de Vouga onde se localizavam cavalarias em finais do século XIII $^{5}$ estão assinaladas no esboço topográfico da Figura 7 através de círculos. O diâmetro de cada círculo é proporcional ao número de cavalarias existentes.

A aristocracia da região estava particularmente concentrada na ribeira do Águeda, sobretudo na sua metade ocidental. É aqui que se regista o maior número de cavalarias numa mesma povoação: 7,5 cavalarias em Espinhei. Os três mais antigos pontos de travessia do Águeda estão claramente marcados: itinerário ocidental (11,5 cavalarias em Espinhei, Óis e Segadães), estrada mourisca (7 cavalarias em Recardães e Casainho) e itinerário interior (4 cavalarias em Borralha e Assequins). Pelo número de cavalarias existentes junto aos pontos de travessia já podemos suspeitar qual ou quais seriam os itinerários preferidos.

No esboço da Figura 7 estão também assinaladas as igrejas existentes na região do Vouga em 1320, segundo um catálogo dessa época publicado por Fortunato de Almeida (1971). Cada igreja é assinalada por um quadrado cujo tamanho é proporcional ao rendimento dessa igreja. O rendimento de uma igreja, como é sabido, era proporcional ao número de moradores da paróquia a que presidia. Assim, a distribuição

5 Uma inquirição sobre direitos régios realizada na terra de Vouga em 1282 menciona as cavalarias existentes (SILVEIRA, 1943). Dispomos ainda do chamado rol das cavalarias do Vouga (Rocha MADAHIL, 1942), um documento originalmente não datado, mas em que alguém muito posteriormente anotou a data de 1328. Não é claro se esta data se deverá entender como era de César ou como ano de Cristo. Sousa BAPTISTA (1950b) defende, embora com um argumento fraco, que se trataria da era de César e portanto do ano de 1290 (quem utilizar o trabalho deste autor deverá ter em conta a existência de algumas falhas na enumeração de cavalarias que nele se apresenta (p. 185)). A inquirição de 1282 e o rol são razoavelmente concordantes. No conjunto das duas inquirições, documenta-se a existência de cavalarias em 39 povoações. Destas, 25 são referidas em ambos os documentos, embora para 6 delas o número de cavalarias indicado seja diferente; para 5 povoações, apenas a inquirição de 1282 menciona as cavalarias; para 9 outras povoações, apenas o rol o faz. Na Figura 5 marquei todas as 39 povoações. O diâmetro do círculo que assinala cada uma é proporcional ao número de cavalarias indicado na inquirição de 1282 ou, sendo esta omissa, no rol.

Conimbriga, 39 (2000) 191-258 
geográfica das igrejas medievais e os seus rendimentos são indicadores importantíssimos sobre a estrutura do povoamento antigo.

É importante notar que, sendo a Igreja Católica uma instituição tradicionalmente conservadora, a rede de igrejas reflecte uma conjuntura, em termos geográficos e de vias de comunicação, muito anterior à fundação da nacionalidade. Até ao século XIX poucas foram as paróquias criadas em regiões de povoamento antigo. A maior parte das igrejas mencionadas no citado catálogo de 1320 já apareceram também num rol de igrejas datável de 1209-1229 6 e nas inquirições de Dom Afonso II de $1220^{7}$. Outras, que aparecem no catálogo de 1320, mas não aparecem nem no rol nem nas inquirições de 1220, estão, ainda assim, referenciadas em documentos anteriores ao século XIII. Tal é o caso das igrejas de Santiago de Riba-Ul (DC 25), Antes (DC 444) e São João da Madeira (DC 704).

O esboço da Figura 7 é bastante elucidativo. Por ele se vê que a rede hidrográfica e a linha do litoral foram dois factores importantes na fixação do povoamento. $O$ principal foco de povoamento situava-se precisamente na zona de confluência dos três maiores rios da região, o Vouga, o Águeda e o Cértima. Aqui encontramos a capital tradicional de toda esta região, a civitas Marnel, e, mesmo no centro, a vila de Ois da Ribeira, que em 1220 era sede de um grande julgado. O facto de Ois da Ribeira se encontrar no centro do principal foco de povoamento sugere, desde logo, que por ali passaria a estrada Coimbra-Porto, tanto mais que Óis, com os seus 28 casais, era o maior aglomerado populacional da região. O eixo Ouca-Aveiro-Cacia, que acompanha a linha do litoral antigo, também apresentava já um razoável grau de desenvolvimento, particularmente visível através dos elevados rendimentos das igrejas.

Entretanto, quem olhar mais atentamente para o esboço, logo verá que a rede hidrográfica não justifica totalmente a estrutura do povoamento. Veja-se o caso do vale do Cértima. Em princípio, se o critério fosse apenas a proximidade do rio, a densidade do povoamento seria

6 A região a sul do rio Antuã, pertencente ao Bispado de Coimbra, está publicada em Milenário, doe. 29, p. 44-50. A região a norte desse rio foi publicada por MAtтoso \{et al. 1993, doc. 9, p. 109-111).

7 A parte das inquirições de 1220 referente ao distrito de Aveiro está publicada em Milenário, doc. 33, p. 56-66. Estas inquirições não chegaram a abranger a Terra de Santa Maria. No entanto, do mesmo ano existem umas inquirições sobre bens religiosos nesse território (MATTOSO et al., 1993, doc. 7, p. 105-107). 
igual em ambas as margens. Na zona propriamente bairradina do vale do Cértima seria até de esperar uma maior densidade de povoamento na margem oriental, pois por ela correm três importantes afluentes, os rios de Arcos, Avelãs e Aguada. No entanto, é precisamente na outra margem que encontramos maior densidade de povoamento. Mais a norte, os férteis campos da ribeira do Cértima justificariam um povoamento denso, similar ao que se regista na ribeira do Agueda. No entanto, pelo esboço da Figura 7 se vê que, a norte de Sangalhos, o povoamento na margem esquerda do Cértima é quase nulo, enquanto o da margem direita passa a ser bastante denso. Isto é tanto mais para estranhar quanto é nesta zona e pela margem esquerda que o Cértima acolhe o seu principal afluente, o rio Levira. Aquilo que acabei de referir sugere que o itinerário mais antigo da região seguia inicialmente pela margem ocidental do Cértima, cruzando este rio entre Sangalhos e Barro e o Águeda em Óis da Ribeira. Este é precisamente o itinerário ocidental a que me referi acima.

Verdadeiramente sugestiva é a posição relativa dos pontos assinaladas no esboço. Na verdade, a distribuição geográfica das povoações apresenta certos alinhamentos que dificilmente se poderão explicar sem recurso à rede viária. Isto é particularmente evidente na margem ocidental do Cértima, onde se detectam dois alinhamentos muito nítidos.

Um desses alinhamentos compõe-se da seguinte sucessão de 4 povoações, cada uma delas com a sua igreja: Murtede, Sepins, Bolho e Vilarinho do Bairro. Este alinhamento corresponde ao antigo caminho de ligação do litoral aveirense a Coimbra. No século XVIII, a estrada Coimbra-Aveiro continuava a passar por Murtede, Samel e Mamarrosa (Teodoro de Matos, 1980). Portanto, atendendo ao encadeamento do povoamento antigo, a primitiva estrada do litoral deveria seguir de perto o contorno da bacia do rio Boco. Depois de Mamarrosa, a estrada passaria por Bustos, Ouca, Sôza, flhavo, Verdemilho e Aveiro. Este caminho aparece referido como via coimbrã («viam colimbrianam») em dois documentos medievais, um de Ilhavo de 1095 (LP 302) e outro de Murtede de 1119 (LP 100). A este antigo itinerário deveremos ainda associar a albergaria e hospital de Sôza, fundados por Dom Sancho I em 1192 e entregues à Ordem de Santa Maria de Rocamador, e um outro hospital fundado em Ouca em 1453 (Correia, 1944, p. 431 e 414). Sôza viria a ser a sede da Ordem de Rocamador em Portugal (Idem, p. 339-347). É natural que todo este itinerário tenha origem romana, sendo Cada o seu destino final.

Conimbriga, 39 (2000) 191-258 
Note-se que, nos primeiros tempos da monarquia, Aveiro não era ainda a vila importante que veio a ser a partir do século XV. No século XVIII a estrada, depois de Vilarinho, seguia directamente para Aveiro (Teodoro de Matos, 1980). Junto a esse novo traçado surgiram povoações hoje grandes e bem conhecidas, como é o caso da Palhaça (povoação só documentada a partir do século XVII) ou até da Quinta do Picado. A ligação de Aveiro à zona Mogofores-Sangalhos, hoje muito utilizada, também deve ser mais recente, pois a estrutura do povoamento antigo não dá dela qualquer testemunho.

Outro alinhamento de povoações na margem ocidental do Cértima, ainda mais nítido no esboço da Figura 7 do que o anteriormente referido, é composto por uma sucessão de 8 povoações: Casal Comba, Antes, Arinhos, Ventosa do Bairro, Horta, Óis do Bairro, Mogofores e Sangalhos. Este alinhamento de povoações corresponde seguramente ao traçado da estrada mourisca ou estrada coimbrã velha cuja passagem em Mogofores e em Ventosa do Bairro está atestada na documentação medieval, como já referi na secção anterior.

É nesta zona da margem ocidental do Cértima, atravessada pela estrada de Aveiro e pela estrada do Marnel, que encontramos também a maior densidade de achados arqueológicos da época romana.

Das 16 povoações da margem ocidental do Cértima assinaladas na Figura 7, apenas quatro (Oliveira do Bairro, São Lourenço do Bairro, Tamengos e Ourentã) não se encontram sobre o traçado de importantes itinerários antigos.

$\mathrm{Na}$ margem oriental do Cértima e a sul do rio de Aguada, o povoamento era bastante mais disperso, não se identificando com suficiente nitidez na Figura 7 alinhamentos de povoações que possam corresponder a itinerários de ligação do Marnel a Coimbra. Em todo o caso, Arcos, Alféloas e Aguada de Cima situam-se sobre o traçado do itinerário interior que defini na sepção precedente. Aguada de Baixo é a única povoação assinalada na Figura 7 que fica situada sobre o traçado da estrada coimbrã do século XIII (a actual cidade de Agueda desenvolveu-se em torno da igreja de Santa Eulália após a construção da ponte do Águeda, na segunda metade do século XIII). E flagrante o contraste com a estrada velha da margem ocidental, junto à qual se assinalam na Figura 7 nada menos do que oito povoações, como referi. O alinhamento formado por Avelãs de Cima, Moita, Vila Nova de Monsarros e Vacariça está já demasiado afastado da zona de circulação norte-sul para que possamos associá-lo a um itinerário importante. 
Algumas destas povoações da margem direita devem, sim, ser associadas a itinerários de ligação à Beira Alta. Estão neste caso Vacariça, Arcos e Moita (Seabra Lopes, 1994b).

Tal como sugere o alinhamento do povoamento antigo, a estrada velha devia cruzar o Cértima entre Sangalhos e Barro. A partir de Barro e, novamente, tendo em conta a estrutura do povoamento, identificam-se dois itinerários alternativos. Um deles seguia por Recardães, povoação sede de freguesia e onde se concentravam cinco casais de cavalaria. O outro seguia ao longo do Cértima por Paradela, Espinhei, Óis da Ribeira, cruzava aqui o rio Águeda, e continuava ao longo do Vouga por Travassô, Segadães e Covelas. Este segundo itinerário é o mais nítido na estrutura do povoamento. A passagem deste itinerário certamente contribuiu para a maior densidade de povoamento que se regista na margem esquerda do Vouga (3 igrejas em Travassô, Segadães e Covelas e 3 cavalarias em Segadães) em comparação com a margem direita (apenas 1 igreja em Alquerubim e 2 cavalarias em Fontes e Calvães).

Este último segmento da estrada, compreendido entre Travassô e Lamas, tocava um antigo itinerário de ligação da zona de Viseu ao litoral. Talvez a bem documentada estrada romana Viseu-Marnel tivesse continuação por Covelas, Segadães, Travassô (onde, segundo a tradição, se situou uma albergaria), Eirol, Horta e Eixo até ao povoado romano de Cacia. Um documento de 1481 refere-se a esta estrada como sendo «huua grande estrada» que ligava Aveiro a Viseu, Lamego, Covilhã e Guarda bem como ao reino de Castela (Sousa BAptista, 1959). A esta estrada deveremos associar o topónimo Fundo da Rua, que designa um lugar próximo de Valongo do Vouga.

Os principais pontos de travessia dos rios nesta zona de confluência eram já em 1481 os mesmos que hoje (Sousa Baptista, 1959, p. 49 e 52): o Águeda atravessava-se entre Almeara e Eirol (onde já em 1377 existia uma ponte), entre Travassô e Óis da Ribeira e, naturalmente, entre Águeda e o Sardão; o Cértima atravessava-se em Requeixo.

Em conclusão, a estrutura do povoamento antigo da região do Vouga reflecte não só a influência de factores geográficos, como sejam a proximidade do litoral ou das margens dos rios, como também o carácter estruturante da rede viária. Nesse sentido, pode dizer-se que o itinerário ocidental foi verdadeiramente a coluna vertebral do povoamento da região do Vouga até ao século XIII. 


\section{Densidade do povoamento antigo ao longo dos vários itinerários}

Dos quatro itinerários entre Coimbra e o Marnel, apresentados em linhas gerais na secção 4, pareceu-me que o itinerário ocidental seria o mais utilizado na época romana. Apresentei bastantes evidências a favor de tal hipótese nas secções 4 e 5. Em seguida, tentarei complementar a argumentação com uma avaliação da densidade do povoamento antigo na vizinhança daqueles quatro itinerários e ainda na vizinhança do itinerário romano Marnel-Gaia.

Essa avaliação será feita em função dos seguintes indicadores: 1) Vestígios romanos; 2) Povoações referenciadas até ao século XII; 3) Casais em 1220; 4) Cavalarias em 1282-1328; 5) Igrejas em 1320 e respectivos rendimentos.

Só considerarei que um certo ponto de interesse (vestígio romano, povoação antiga, casal ou igreja) fica na vizinhança de um certo itinerário se ficar a menos de meia milha de distância desse itinerário ${ }^{8}$ e não houver, entre o itinerário e o ponto de interesse, um obstáculo importante, como seja um rio. Por outro lado, não considerarei como pontos de interesse os extremos dos itinerários estudados, isto é, Coimbra, Marnel e Porto/Gaia.

A comparação entre os vários itinerários será feita em termos de indicadores denominados densidades. Uma densidade será uma normalização, para um módulo viário de 100 milhas, do número de vestígios, povoações, casais ou igrejas na vizinhança de um itinerário. Assim, por exemplo, o itinerário entre o Marnel e Vila Nova de Gaia tocava em 12 igrejas. Como, pelos meus cálculos, este itinerário mede de comprimento cerca de 42,9 milhas, a densidade de igrejas no seu traçado é de $12 x 100 / 42,9=28$ igrejas por cada 100 milhas. As distâncias correspondentes aos vários itinerários foram já apresentadas na Tabela II.

A ausência de povoamento antigo e, nomeadamente, de vestígios romanos, ao longo do traçado da estrada coimbrã tem levado alguns autores a considerar bastante deserta toda esta região compreendida, grosso modo, entre a Mealhada e Albergaria-a-Velha. A realidade é inteiramente diversa. Por exemplo, Ruy de Azevedo preparou um esboço topográfico das vilas rústicas da região a sul do Vouga na posse

${ }^{8}$ Dentro desta vizinhança ficaria a pars urbana da maior parte das villae que confrontassem com a estrada. A propósito das dimensões das villae, veja-se o artigo de Alareão (1998).

Conimbriga, 39 (2000) 191-258 
total ou parcial do mosteiro do Lorvão em finais do século $\mathrm{X}$, época em que Almançor tomou para o dominio árabe todo o territorio até ao Douro. Baseado nesse esboço, o autor concluiu: «Descobre-se não só a expansão e riqueza do mosteiro, como o intenso povoamento que grande parte desta zona atingiu no decorrer do século $\mathrm{X}$; este último ainda se torna mais evidente, através dos documentos, pela existência de inúmeras igrejas disseminadas por todo o território, e pelo parcelamento da propriedade em algumas regiões, como por exemplo em Vila Cova e Recardães» (AzEvedo, 1933, p. 204).

Quanto aos vestígios romanos, José Rodrigues, na sua obra sobre o couto de Aguim, fez uma inventariação dos que conhecia na Bairrada que o levou a concluir: «O espólio arqueológico, etnográfico e toponímico da região revela este facto incontroverso: foi duradoura e profunda a romanização» (RodRIGUEs, 1959, p. 10).

O mesmo autor verificou ainda que «tais vestígios são especialmente abundantes na vertente oeste do vale do Cértima, nas colinas de Casal Comba, Pedrulha, Murtede, Sepins, Arinhos e Horta [...]. Muitos outros vestígios têm aparecido nas encostas e planaltos que se sucedem até alturas de Mogofores, alguns deles de descoberta recente» (RoDRIGues, 1959, p. 10-11). Mário Saa, homem da investigação no terreno, escreveu também: «Os acidentes arqueológicos mais notáveis prolongam-se sobre a esquerda do Sértoma, nas encostas e ao longo do rio» (SAA, 1960, p. 116). E noutro ponto: «Bairrada, região de muita antiguidade romana, sobretudo na margem ocidental do Sértoma» (idem, p. 177). Pelos elementos que pude reunir, estas afirmações mantêm-se válidas e apoiam a passagem da estrada romana na margem ocidental do Cértima.

$\mathrm{Na}$ tabela III eunumeram-se os vestígios romanos até agora encontrados na vizinhança dos quatro itinerários Coimbra-Marnel e no itinerário romano Mamel-Gaia. As fontes desta enumeração são a obra Roman Portugal (Alarcão, 1988a = RP) e, ainda, diversas monografias mais localizadas. Não são incluídos nesta inventariação vestígios de estradas, pois a maior parte dos que se conhecem são medievais ou mesmo modernos, e, se alguns há que sejam romanos, ainda não foi possível comprová-lo inequivocamente. Pela tabela III se vê que, dos quatro itinerários de ligação entre Coimbra e Marnel, a estrada coimbrã é o que apresenta menor densidade de vestígios arqueológicos romanos ao longo do seu traçado. Se considerarmos apenas a parte destes itinerários a norte do Carquejo, local da bifurcação, o contraste entre os itinerários da margem ocidental e a estrada coimbrã é ainda mais nítido. 
TABELA III - Densidade de vestígios romanos

\begin{tabular}{lcc}
\hline Locais onde apareceram vestígios romanos & Total & Densidade \\
\hline Coimbra-Marnel (itinerário ocidental ou romano) & & \\
Ingote (RP 3/102); São Martinho do Pinheiro (RP 3/83); & & \\
Trouxemil (RP 3/96); Vimieira (RP 3/81); Casal Comba (RP 3/80); 11 & 28 \\
Arinhos (RODRIGUES, 1959, p. 11); Horta (RoDRIGUES, 1959, p. 15); & \\
Ois do Bairro (SAA, 1960, p. 177); Mogofores (RoDRIGUES, & \\
1959, p. 11; CRUZ, 1995, II, p. 372); Sangalhos (MALHEIRO, 1997); & \\
Piedade (RP 3/62); & & \\
\hline
\end{tabular}

Coimbra-Marnel (estrada mourisca)

Igual ao anterior até Sangalhos;

10 27

Coimbra-Marnel (itinerário interior)

Igual ao anterior até Trouxemil; Mealhada (RP 3/79);

Aguim (Rodrigues, 1959, p. 15); Monte Crasto (SILVEIRA, 1911;

NogueIra GonÇAlves, 1959); Aguada de Cima (RP 3/63);

7

19

Coimbra-Marnel (estrada coimbrã)

Igual ao anterior até Mealhada; Aguada de Baixo (RP 3/64);

5

Marnel-Gaia (estrada romana)

Gándara de Serém (SousA BAPTISTA, 1950, p. 101);

Branca (SILVA, 1994, p. 46-47; RP 3/39);

UI (RP 3/36; SILVA, 1994, p. 57);

Mamoinha da Mourisca / Arrifana (Leite De Vasconcelos, 1913,

p. 507; FERNANDES, 1996, p. 59-61);

Fiães (RP 3/29); Castro da Senhora da Saúde (RP 3/9);

Mafamude (SILVA, 1994, p. 61);

Poderá parecer estranho que, no traçado da estrada romana entre o Mamei e Vila Nova de Gaia, se tenha encontrado também uma baixa densidade de vestígios. No entanto, é preciso não esquecer que a região entre Vouga e Mondego estava sob a influência directa de dois grandes centros romanos, Conímbriga e Emínio. Ao que parece, a mancha de maior densidade arqueológica prolonga-se de Coimbra (Emínio) por toda a margem norte do Mondego e mais para norte até à Bairrada, sobretudo a ocidente do Cértima. A partir daqui, apesar de nos estarmos a aproximar de Talábriga, diminuem gradualmente as notícias de achados. Talábriga é a última cidade da cadeia de cidades enumeradas por Plínio e atribuídas aos Túrdulos por Pomponio Mela. A norte do 
Vouga, onde a cultura castreja era dominante, a romanização parece ter sido mais tardia e menos intensa.

TABELA IV — Densidade de povoações referenciadas até ao século XII

\begin{tabular}{lcc}
\hline Povoações referenciadas, ano e documento & Total Densidade \\
\hline Coimbra-Marnel (itinerário ocidental ou romano) & & \\
Coselhas, 967 (DC 94); Cioga do Monte, 968 (DC 95); & & \\
Trouxemil, 883 (DC 11); São Martinho do Pinheiro, 973 (DC 196); & \\
Vimieira, 973 (DC 196); Casal Comba, 1094 (LP 175); & \\
Antes, 1064 (DC 444); Arinhos, 1064 (DC 444); Ventosa, 1064 & \\
(DC 444); Horta, 1064 (DC 444); Óis do Bairro, 1086 (LP 101) & 23 \\
Mogofores, 1143 (DR 201); Sá, 1143 (DR 201); Sangalhos, 957 & 54 \\
(DC 73); Barró, 957 (DC 73); Paradela, 982 (AzEVEDo, 1933, p. & \\
221); Espinhei, 982 (AZEVEDo, 1933, p. 221); Óis da Ribeira, 1101 & \\
(LP 553); Travassô, 883 (DC 11); Segadães, 1050 (DC 378); & \\
Crastovães, 981 (DC 132); Covelas, 1050 (DC 378); Pedaçães, 981 & \\
(DC 132); & \\
\hline
\end{tabular}

Coimbra-Marnel (estrada mourisca)

Igual ao anterior até Barro; Recardães, 981 (DC 131); Castro, 982
(AZEVEDO, 1933, p. 221); Paredes, 1046 (DC 348);

$18 \quad 49$

Coimbra-Marnel (itinerário interior)

Igual ao anterior até São Martinho do Pinheiro; Sernadelo, 1140

(DR 179); Aguim, 1101 (DP/III 17); Anadia, 1082 (LP 53); Arcos,

943 (DC 51); Santa Eulália de Aguada de Cima, 957 (DC 73) /

$13 \quad 36$

1132 (DR 123); Borralha, 1114 (DP/III 493); Assequins, 1050 (D

378); Valongo, 1050 (DC 378); Lanheses, 1101 (DP/III 42);

Coimbra-Marnel (estrada coimbrã)

Igual ao anterior até Sernadelo; Avelãs de Baixo, 1132 (DR 123);

8

23

Aguadela, 957 (DC 73); Aguada de Baixo, 957 (DC 73);

Marnel-Gaia (estrada romana)

Serem, 1050 (DC 378); Assilhó, 1117 (DR 49); Branca, 1088 (DC

708); Curvai, 1109 (DP/III 318); Figueiredo, 1115 (DP/III 503);

Oliveira de Azeméis, 922 (?) (DC 25); Santiago de Riba-Ul, 922 (?)

(DC 25); Manhouce, 1053 (DC 385); São João da Madeira, 1088

(DC 703); Fiães, 1181 (ANTT, Suplemento da Colecção Especial -

sala 16, mosteiro de Pedroso, m. 4, n. ${ }^{\circ}$ 16), Gualtar, 1181 ( );

Aldriz, 897 (DC 12); Argoncilhe, 1091 (DC 756); Ramil, 1109

(DP/III 344); Seixezelo, 1091 (BF 196); Seada, 1119 (DP/IV 96);

Pedroso, 1059 (DC 378); Mafamude, 922 (?) (DC 25); 
Como tenho vindo a referir, desde finais do século XII ter-se-ão produzido diversas alterações ao traçado da estrada mourisca. $\mathrm{O}$ estudo da estrutura do povoamento anterior a essas alterações poder-nos-á dar indicações importantes para a reconstituição do traçado da estrada mourisca primitiva. Na tabela IV, enumeram-se as povoações ainda actualmente existentes e que aparecem referidas na documentação até ao século XII ${ }^{9}$. Não são incluídas nesta enumeração as povoações hoje desaparecidas, pois em muitos casos se desconhece qual terá sido a sua exacta localização.

Mais uma vez, o itinerário ocidental e a estrada mourisca entre Coimbra e Mamei são os que apresentam maior densidade de pontos de interesse. A densidade de pontos de interesse ao longo da estrada romana entre Mamei e Gaia já se aproxima da densidade dos valores da estrada mourisca e do itinerário ocidental a sul do Marnel. Novamente, a estrada coimbrã a sul do Mamei aparece em último lugar.

Uma fonte importante sobre o povoamento da região entre Vouga e Buçaco são as inquirições de 1220 (Milenário, doc. 33) que abrangem o espaço correspondente à terra de Vouga. Nela se referem não só as povoações existentes, como também, em muitos casos, o número de casais pertencentes a vários senhores. Para a zona bairradina, no entanto, quase não se mencionaram os casais. $\mathrm{Na}$ tabela $\mathrm{V}$, apresentam-se os casais existentes ao longo dos itinerários considerados, segundo as inquirições de 1220, bem como as densidades de casais. Aqui, sobressaem claramente os dois itinerários que contornam a ribeira do Agueda, o itinerário ocidental (travessia em Óis) e o itinerário interior (travessia em Assequins). No traçado da estrada coimbrã não foi referenciado um único casal.

TABELA V - Densidade de casais em 1220

\begin{tabular}{lcc}
\hline Casais registados em cada povoação & Total & Densidade \\
\hline $\begin{array}{l}\text { Coirnbra-Marnel (itinerário ocidental ou romano) } \\
\text { Sá, 1; Paradela, 11; Espinhei, 12,5; Óis, 28; Crastovães, 7; } \\
\text { Covelas, 4; Pedaçães, 3; }\end{array}$ & 66,5 & 168 \\
\hline
\end{tabular}

${ }^{9} A s$ fontes utilizadas são referenciadas na tabela por siglas (DC, DP/III, DP/IV, LP, BF, etc.) tal como indicado na bibliografia apresentada no fim do artigo.

Conimbriga, 39 (2000) 191-258 
Coimbra-Marnel (estrada mourisca)

Sá, 1; Recardães, 27;

Coimbra-Marnel (itinerário interior)

Alfeloas, 1; Pereiro, 9; Borralha, 5; Assequins, 18,5;

Valongo, 18; Carvalhal, 2;

Coimbra-Marnel (estrada coimbrã)

Não foram registados nenhuns casais

0

0

Marnel-Gaia (estrada romana)

Não abrangido pelas inquirições de 1220

Outro indicador importante sobre o povoamento antigo, já posto em destaque na secção 5, é a existência de casais de cavalaria. A Tabela VI apresenta as cavalarias e densidades de cavalarias ao longo dos quatro itinerários entre Marnel e Coimbra. Mais uma vez o itinerário ocidental se destaca e, mais uma vez, é flagrante o contraste com a estrada coimbrã.

Ainda outro importante indicador do povoamento, também já realçado na secção 5, é a distribuição geográfica das igrejas. A Tabela VII apresenta os rendimentos das igrejas situadas na vizinhança dos itinerários considerados segundo o catálogo de 1320 (ForTunATO DE ALMEIDA, 1971) bem como as densidades associadas. A tabela VIII apresenta o número e densidade de igrejas nos mesmos itinerários. Convém notar que a maior parte destas igrejas já aparecem nas listas do princípio do século XIII e muitas delas são referenciadas em documentação muito mais antiga ainda (as únicas igrejas que não encontrei referenciadas antes de 1320 são as de Trouxemil, UI e Seixezelo). Portanto, as tabelas VIII e IX reflectem uma conjuntura seguramente anterior à época em que se começaram a operar as rectificações ao traçado da estrada mourisca. Destas tabelas resulta que a densidade de igrejas e do respectivo rendimento no itinerário ocidental e na estrada mourisca estão na mesma ordem de grandeza da estrada romana Marnel-Gaia. A estrada coimbrã a sul do Marnel ficou novamente em último lugar. 
Tabela VI - Densidade de casais de cavalaria em 1282-1328

\begin{tabular}{lcc}
\hline Casais de cavalaria registados em cada povoação & Total & Densidade \\
\hline $\begin{array}{l}\text { Coimbra-Marnel (itinerário ocidental) } \\
\text { Arinhos, 3; Horta, 1; Óis do Bairro, 2; Mogofores, 1; } \\
\text { Paradela, 1; Espinhei, 7,5; Óis da Ribeira, 1; Segadães, 3; }\end{array}$ & 19,5 & 49 \\
\hline $\begin{array}{l}\text { Coimbra-Marnel (estrada mourisca) } \\
\text { Igual ao anterior até Mogofores; Recardães, 5; Casainho, 2; }\end{array}$ & 14 & 38 \\
\hline $\begin{array}{l}\text { Coimbra-Marnel (itinerário interior) } \\
\text { Arcos, 1; Alfeloas, 2; Borralha, 2; Assequins, 2; Arrancada, 1; }\end{array}$ & 12 & 33 \\
Brunhido, 1; Lanheses, 2; Cristelo, 1; & & \\
\hline $\begin{array}{l}\text { Coimbra-Marnel (estrada coimbrã) } \\
\text { Não foram registados casais de cavalaria junto a este itinerário }\end{array}$ & 0 & 0 \\
\hline $\begin{array}{l}\text { Marnel-Gaia (estrada romana) } \\
\text { Não abrangido por estas inquirições }\end{array}$ & - & - \\
\hline
\end{tabular}

Tabela VII — Rendimentos das igrejas em 1320

\begin{tabular}{lcc}
\hline Igrejas e respectivos rendimentos & Total & Densidade \\
\hline $\begin{array}{l}\text { Coimbra-Marnel (itinerário ocidental ou romano) } \\
\text { Treixomil, 25; Antes, 20; Casal Comba, 110; Ventosa, 50; }\end{array}$ & 942 & 2379 \\
$\begin{array}{l}\text { Óis do Bairro, 12; Sangalhos, 230; Barro, 60/2 (?); Espinhei, 200; } \\
\text { Óis da Ribeira, 80; Travassô, 60; Segadães, 80; Covelas, 45; }\end{array}$ & & \\
\hline $\begin{array}{l}\text { Coimbra-Marnel (estrada mourisca) } \\
\text { Igual ao anterior até Barro, total 477; Recardães, 100; }\end{array}$ & 577 & 1559 \\
\hline $\begin{array}{l}\text { Coimbra-Marnel (itinerário interior) } \\
\text { Treixomil, 25; Arcos, 90; Aguada de Cima, 80; Valongo, 190; }\end{array}$ & 385 & 1055 \\
\hline $\begin{array}{l}\text { Coimbra-Marnel (estrada coimbrã) } \\
\text { Treixomil, 25; Aguada de Baixo, 60/2 (?); Águeda, 180; }\end{array}$ & 235 & 681 \\
\hline
\end{tabular}

Marnel-Gaia (estrada romana)

Figueiredo, 140; ermitânia de Figueiredo, 25; Branca, não diz, adopta-se o valor médio 50; Ul, 40; igrejas de Oliveira de Azeméis e Lações, 45; Vila Coua de Ul (^Santiago de Riba-Ul), 50;

São Joãoda Madeira, 80; Manhuci (=Arrifana), 60; Fiães, 60;

Seixezelo, 25; Argoncilhe, não diz, adopta-se o valor médio 50; 
TABELA VIII - Número e densidade de igrejas

\begin{tabular}{lcc}
\hline & $\begin{array}{c}\text { Número } \\
\text { de igrejas }\end{array}$ & Densidade \\
\hline Coimbra-Marnel (itinerário ocidental ou romano) & 12 & 30 \\
\hline Coimbra-Marnel (estrada mourisca) & 8 & 22 \\
\hline Coimbra-Marnel (itinerário interior) & 4 & 11 \\
\hline Coimbra-Marnel (estrada coimbrã) & 3 & 9 \\
\hline Marnel-Gaia (estrada romana) & 12 & 28 \\
\hline
\end{tabular}

\section{A deslocação do eixo do povoamento para a nova estrada coimbrã}

Nos primeiros tempos da monarquia portuguesa, fizeram-se importantes rectificações do traçado da estrada mourisca. Esta, por sua vez, passou a chamar-se estrada coimbrã. O novo traçado imprimiu uma nova estrutura ao povoamento. Ao longo do novo traçado surgem novas povoações, que progressivamente se transformam em centros económicos e político-administrativos.

Miguel de Oliveira atribuía a estagnação da vila da Feira ao seu afastamento da estrada real: «Por lhe passar desviada a nascente a estrada principal é que tão pouco se tem desenvolvido a sede de tão importante concelho») (OLIVEIRA, 1943, p. 57).

$\mathrm{O}$ caso mais bem caracterizado parece ser o de Figueiredo. Em tomo desta povoação bipolar (Figueiredo de Baixo e Figueiredo de Cima) se organizou um julgado que já existia no século XIII. A estrada romana deve ter passado em Figueiredo, pois logo a norte, em Ul, apareceu um miliário. A estrada mourisca passava seguramente em Figueiredo, porque o rei tinha aí um paço de pernoita. Em Figueiredo, no ano de 1114, celebraram os bispos do Porto e de Coimbra uma importante convenção sobre a fronteira entre as respectivas dioceses (DP/III 526). Ao desvio do traçado mais para o interior, ocorrido talvez em meados do século XIII, se deve atribuir o nascimento de Pinheiro e Bemposta. Nenhuma destas povoações aparece mencionada nas inquirições de 1220. Uma inquirição de 1284 refere mesmo que a Bemposta tinha sido criada pouco tempo antes; finalmente, em 1290, 
a sede do julgado era já na Bemposta ${ }^{10}{ }^{11}$. Por sua vez, o paço real passou a ser no Curvai. No século XVI, o concelho continuava a dizer-se de Figueiredo e a sede permanecia na Bemposta (BraAmcamp Freire, 1908, p. 277). No Pinheiro e na Bemposta se construíram nos séculos XVII e XVIII várias casas solarengas que dão a estas duas terras ar de certa antiguidade. Em Figueiredo, decadente após a alteração do traçado da estrada, já nada testemunha a sua antiga importância.

Entre Vouga e Mondego, foram verdadeiramente radicais as transformações geomorfológicas e da rede viária operadas desde o princípio da monarquia, transformações estas que alteraram completamente a estrutura do povoamento antigo, tal como ela nos apareceu no esboço da Figura 7. Para termo de comparação, apresenta-se na Figura 8 o esboço topográfico dos principais centros de povoamento na mesma região segundo o Recenseamento Geral da População de $1940{ }^{\text {n }}$. Foram assinaladas apenas as povoações com mais de 200 fogos (círculos) e as sedes das freguesias com um total superior a 500 fogos (quadrados).

Da comparação entre os esboços topográficos das Figuras 5 e 6 resultam evidentes alguns factos. Em primeiro lugar, o centro de gravidade do povoamento da região deslocou-se da zona de confluência de Vouga, Agueda e Cértima para a ria de Aveiro, cujo processo de formação terminou em meados do século XVIII. Podemos dizer que o centro de gravidade da região acompanhou o deslocamento da foz do Vouga. A própria capitalidade administrativa da região, que desde a época romana se situava no Marnel, foi deslocada para Aveiro. Os limites da chamada comarca de Aveiro, criada no século XVI e sediada em Esgueira, pouco se afastavam dos limites do território medieval de Vouga e dos limites romanos de Talábriga (SEABra Lopes, 1995; 1996a).

10 Em 1284: «A Benposta, que pobrou o almoxarife novamente, ....» (MATToso et al., 1993, doc. 70, p. 217); em 1290: «... dixerom a Paay Johannes, juiz de Figheiredo na Benposta, ... » (MATTOso et al.,1993, doc. 100, p. 269).

11 Por incrível que pareça, em toda a história portuguesa, apenas cinco numeramentos de população realizados a nível nacional mencionam a população existente em cada aglomerado populacional. São eles o cadastro de população de 1527 e os censos oficiais de $1911,1940,1960$ e 1991. Todos os outros numeramentos limitam-se a apresentar os totais por freguesias ou por concelhos. Não utilizei o cadastro de 1527 para comparação com o povoamento antigo porque este numeramento não apresenta a população de algumas localidades importantes da região em estudo como sejam Anadia, Mealhada, Vila Nova de Monsarros, Casal Comba e Aguada de Cima. Também não utilizei o censo oficial de 1911 porque o exemplar que tenho mais à mão está incompleto. 
Quanto à rede viária, a comparação entre as Figuras 5 e 6 ilustra claramente as transformações ocorridas. $\mathrm{O}$ itinerário ocidental ou romano, tão nítido na Figura 7 , já não se vislumbra na Figura 8. Em compensação surge, mais para o interior, um alinhamento de povoações muito nítido, o qual segue de perto a estrada coimbrã; Mourisca do Vouga, Águeda, Aguada de Baixo, Avelãs do Caminho e Mealhada. Na Figura 8, aparecem ainda Assequins, Borralha, Arcos, Anadia e Aguim, povoações que ficam razoavelmente próximas da estrada coimbrã e que prosperaram graças a essa proximidade. Finalmente, o alinhamento formado pelas povoações de Sangalhos, Oliveira do Bairro, Oiã, Póvoa do Valado, Oliveirinha e São Bernardo, todas assinaladas na Figura 8, corresponde à estrada Malaposta-Aveiro. Esta estrada, que já existia no século XVII, embora com um traçado algo diferente do actual (SEABRA LOPES, 1994b, p. 99-100), não deve ter grande antiguidade. Com efeito, não se vislumbra qualquer vestígio dela na estrutura do povoamento antigo (Figura 7).

Entre o Marnel e Coimbra, onde me parece que as alterações do traçado da estrada foram mais radicais, são numerosos os casos tipo Figueiredo/Bemposta. Enquanto junto aos itinerários ancestrais e, mesmo, junto à estrada mourisca, se localiza um grande número de povoações que aparecem referenciadas na mais antiga documentação portuguesa (algumas desde o século IX), as povoações da estrada coimbrã surgem ou desenvolvem-se a partir do século XIII.

Começo por Sangalhos, onde se deve ter situado uma mansio da estrada romana e um paço da estrada mourisca (ver secção 8). O topónimo Paço, também dito Sangalhos do Paço, parece ainda recordar o antigo paço real da estrada mourisca ${ }^{12}$. No século XII, a passagem da estrada e a existência do paço real deviam dar alguma projecção regional a Sangalhos. Talvez o mais eloquente vestígio dessa antiga importância de Sangalhos seja a difusão que o alqueire de Sangalhos teve no tempo de Dom Afonso Henriques. De facto, vê-se pelos forais manuelinos que diversas terras importantes pagavam, pelo direito da jugada, uma certa quantidade de cereal medida pelo alqueire de Sanga-

12 De facto, o topónimo paço não é muito frequente nesta região, e, quando ocorre, normalmente tem origem num paço de pernoita do rei. Tal é o caso de Paço de Avelãs e Paço de Figueiredo, na estrada Porto-Coimbra, Paço de Vilarinho, na estrada Aveiro-Coimbra, Paço de Arrancada, na estrada Marnel-Viseu, e Paço de Botão (na estrada de Coimbra para a Beira Alta). 
lhos. Em 1179, Coimbra, Santarém e Lisboa passaram a pagar pela jugada um moio de 56 alqueires da medida de Sangalhos. Também por essa medida se pagava a jugada em Leiria, Torres Vedras e Almada, entre outras. No bispado do Porto era quase geral, desde o século XII, medirem-se pelo alqueire de Sangalhos as censorias pagas ao bispo e cabido ( Censual, p. 543-582). No princípio do século XVI, o alqueire de Sangalhos continuava em utilização corrente em toda a região compreendida entre o rio Antuã e a serra do Buçaco.

Em 1143, a estrada mourisca ainda passava entre Mogofores e Ancas, e, assim, também passaria em Sangalhos. Em 1179, Dom Afonso Henriques determinou que se pagassem as jugadas pelo alqueire de Sangalhos. O nosso primeiro rei terá escolhido o alqueire corrente de um dos seus paços para o pagamento das jugadas. É, pois, natural que em 1179 a estrada mourisca continuasse a passar em Sangalhos. No entanto, em 1220 o paço real já se situava em Avelãs. A estrada, que agora passava entre Mogofores e Arcos, era conhecida como estrada coimbrã. Portanto, a estrada passava agora na margem oriental do Cértima. Talvez seja de atribuir ao rei povoador, Dom Sancho I, que reinou entre 1185 e 1211, a iniciativa da alteração do traçado.

Com a mudança da estrada para a margem direita, Sangalhos passa para segundo plano. No entanto, mantém-se como sede de freguesia. No século XIII, a sede tinha 22,5 casais $^{13}$, pouco menos do que Ois da Ribeira, que era a maior da região, com 28 casais. A igreja de São Vicente de Sangalhos era ainda em 1320 a mais rendosa de toda a Bairrada e uma das mais rendosas do Baixo Vouga ${ }^{14}$. Sangalhos foi também sede de concelho e de capitania-mor. Porém, verdadeiramente impressionante vai ser a evolução de Avelãs.

No século X, Avelãs do Caminho ainda não deveria existir. Depreende-se de um documento de 961 (DC 84) que o topónimo Auleanas era suficiente para identificar a vila rústica a que depois se chamou Auelanas de Susanas (Avelãs de Cima). No século XI, existia no limite de Sangalhos e junto à foz do rio Avelãs, uma vila que parece nem

${ }^{13}$ São os chamados casais antigos reguengos que, segundo o foral manuelino deste concelho, existiam no conjunto de Sangalhos do Paço e Sangalhos da Igreja.

A igreja de São Vicente rendia 230 libras. Rendas maiores registam-se apenas em São Miguel de Aveiro (660 libras), São Miguel de Sôza (650 libras), Santo André de Esgueira (400 libras) e São Miguel de Fermelã (280 libras) (FORTunATO DE AlMeIDA, 1971, p. 123-124).

Conimbriga, 39 (2000) 191-258 
nome tinha: «in Sangalios, uilla quefuit de Elias Exalaba ubi se Auelanas infundit in Certoma » (DC 444). Esta era a vila a que os documentos do século XII e XIII chamam Auelanis de Jusanis (Avelãs de Baixo). Com a mudança da estrada para a margem direita do Cértima, instala-se aí um paço de pernoita da família real, o qual aparece referido nas inquirições de 1220 (Milenário, p. 65). A existência do paço promove a povoação, que rapidamente se constitui em sede de concelho e ganha, a partir do século XIV, o definitivo do Caminho. No século XV, Avelãs do Caminho era já uma das poucas povoações da região com obrigação de ter besteiros do conto (Milenário, p. 160-162). Já na época moderna, esta tendência manifesta-se pela existência em Avelãs de um maior número de familias nobres e burguesas do que em Sangalhos. No século XVI, Avelãs continuava a pertencer à freguesia de Sangalhos. Mas, como não havia na estrada de Coimbra até Aguada uma única igreja onde se rezasse missa, decidiu-se em 1587 que o coadjutor de Sangalhos passaria a rezar missa na igreja de Santo António de Avelãs todos os domingos e dias santos (Rocha MADAhIL, 1944). Este foi o primeiro passo para a criação da freguesia de Avelãs do Caminho, ocorrida no século XIX.

Ainda na zona Sangalhos/Avelãs, se encontram mais alguns exemplos de alterações do povoamento relacionáveis com a alteração do traçado da estrada. Uma das mais antigas povoações da freguesia de Sangalhos era o Casal da Rua ${ }^{15}$, situado na margem ocidental do Cértima e referenciado pela primeira vez nas inquirições de 1220. Com o tempo, este lugar foi-se despovoando e acabou por ficar deserto no século XIX. A Póvoa da Cortiçada, que ficava próxima do Casal da Rua, talvez $1 \mathrm{Km}$ para sul, também desapareceu. Em compensação, na margem oriental, deve ter-se formado nos séculos XIV ou XV a povoação de São João da Azenha. A primeira referência documental que se lhe conhece é do século XVI (Seabra Lopes, 1994b). São João da Azenha é hoje uma das maiores povoações da freguesia de Sangalhos.

Nos antigos coutos de Barro e de Horta, ainda na Bairrada, encontramos mais dois exemplos da influência da rede viária na estrutura do povoamento. Foram estes coutos criados ambos por Dom

15 No século XVII, passava junto ao Casal da Rua uma estrada de ligação da Beira a Aveiro (SEABRa Lopes, 1994, p. 99). Portanto, só se se vier a provar que esta estrada não existia na Idade Média, se poderá relacionar o topónimo Casal da Rua com a velha estrada mourisca da margem ocidental do Cértima. 
Afonso Henriques, respectivamente em 1132 e 1140 (DR 123; DR 179). O couto de Barró ficou a englobar as freguesias de Barró e de Aguada de Baixo. Esta última, que foi minuciosamente descrita num documento de 957 (DC 73), é a única povoação da estrada coimbrã a sul do Mamel anterior ao século XII. Porém, a sede do Couto ficou em Barró, onde julgo que passava a estrada mourisca.

O couto de Horta englobava apenas uma freguesia, cuja sede era Tamengos. Horta e Tamengos ficam na margem ocidental do Cértima, onde passava a estrada mourisca. A estrada romana deve ter passado em Horta. Pertenciam ainda ao couto os lugares de Aguim e Mata. Por volta de 1200, Horta tinha 24 casais, precisamente o dobro dos casais existentes em Aguim, que era a segunda maior povoação do couto ${ }^{16}$. Horta era maior que Sangalhos e pouco menor do que Ois da Ribeira. No entanto, com o desvio da estrada para a margem oriental, Horta perdeu importância e Aguim passou a ser a sede do couto, que ficou modernamente conhecido como couto de Aguim.

A ribeira do Águeda ( Riba d'Águeda) fomece-nos também vários exemplos de como a alteração do traçado da estrada provocou uma alteração da relação de forças entre as povoações da região. Recardães, onde passava a estrada mourisca, é uma povoação extremamente bem documentada desde o século X. Nessa época, Recardães era mesmo uma das zonas de maior parcelamento da propriedade entre Vouga e Mondego (AZEVEDo, 1933, p. 204). A antiguidade do povoamento em Recardães é indicada ainda pela presença da palavra crasto em dois topónimos, estando um deles documentado desde o século X (AzEvedo, 1933, p. 221). Sente-se que Recardães era uma das povoações dominantes da região. Travassô aparece em vários documentos do século IX, incluindo um dos mais antigos documentos portugueses, do ano de 883 (DC 11). Espinhei, que se documenta desde o século X, tinha em 1320 a igreja mais rendosa de Riba d'Águeda e uma das mais rendosas do Baixo Vouga ${ }^{17}$.

16 Na verdade, havia 12 casais em Aguim, 9 na Mata e 8 em Tamengos (RODRIGUES, 1959, p. 182-183). Há uma tradição segundo a qual Horta era a primitiva sede da freguesia \{Idem, p. 14-15). No entanto, a igreja de Tamengos já existia em 1064, não havendo na documentação qualquer referência a uma igreja em Horta (veja-se, por exemplo, a relação de igrejas do bispado de Coimbra de 1209-1229 \{Milenário, doc. 29), onde não se menciona a existência de uma igreja em Horta). A referida tradição certamente se baseia no facto de Horta ter sido a primeira sede do couto.

17 A igreja de Santa Maria de Espinhei rendia 200 libras. Ver acima a nota 13.

Conimbriga, 39 (2000) 191-258 
Em 1220, segundo as inquirições nesse ano realizadas, as maiores povoações de Riba d'Águeda eram Óis, com 28 casais, Recardães, com 27 casais, e Assequins, com 18,5 casais. É interessante notar que estas povoações correspondem precisamente aos pontos de travessia do Águeda pelo itinerário ocidental ou romano, pela estrada mourisca e pelo itinerário interior. A abertura da estrada coimbrã fez aparecer uma quarta povoação, Águeda, que acabou por presidir a toda a região. Em 1282, Espinhei era ainda a povoação em toda a terra de Vouga que tinha mais casais de cavalaria, ao todo 7,5; Recardães vinha em segundo lugar com 5 cavalarias CMilenário, 1959, doc. 47). Convém lembrar que a terra de Vouga era um território enorme, que se estendia de Albergaria-a-Velha até à Mealhada e das abas serranas até Aveiro. Espinhei, Óis da Ribeira, Recardães, Casainho e Oronhe tinham em conjunto mais de uma quarta parte de todas as cavalarias existentes na terra de Vouga. Assim se vê que, ainda em finais do século XIII, a metade ocidental da ribeira do Águeda apresentava uma elevadíssima concentração dos chamados cavaleiros-vilões, a classe dominante no mundo rural. Em 1220, Óis da Ribeira era sede de um julgado que abrangia quase todos os lugares de Riba d'Águeda e ainda se prolongava até Oliveira do Bairro CMilenário, 1939, doc. 33).

Com a construção da ponte sobre o rio Águeda, na segunda metade do século XIII, e o consequente florescimento do burgo de Águeda, estas antigas povoações perdem a importância que tinham. Do julgado de Óis não se volta a falar. Apesar de tudo, séculos mais tarde, Óis ainda veio a ser sede de capitania-mor. A aldeia de Águeda, embora florescente, só foi promovida a sede de concelho após a reforma liberal.

As origens da vila de Águeda têm permanecido numa certa obscuridade. Um documento de 1077 refere a existência de um porto de Sancta Eolalia que ficava situado entre um lugarejo denominado Casal de Lausato, a que a documentação não volta a fazer referência, e a vila rústica de Abciquinis (Assequins) ${ }^{18}$. A existência de uma igreja de

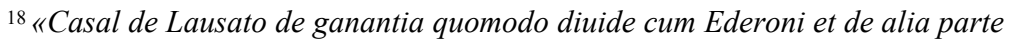
cum Abciquinis, per illo fontano de discurri ad illo porto de Sancta Eolalia » (DC 549). O Conde da Borralha $(1932-39,1)$ situou a igreja de Santa Eulália no próprio Casal de Lausato e fez corresponder este casal ao futuro burgo de Águeda. O documento citado não permite tirar tal conclusão. Dele se deduz apenas que a igreja estava próxima da fronteira entre Assequins e o Casal de Lausato. O facto de, no antigo regime, a povoação de Águeda ter pertencido uma parte ao concelho de Aveiro e outra parte ao conce-

Conimbriga, 39 (2000) 191-258 
Sancta Eolalia de Agada $^{19}$ documenta-se no rol de igrejas de 1209-1229 CMilenário, p. 46). Nas inquirições de 1220, que estão organizadas por freguesias, documenta-se a freguesia de Agada. Esta freguesia englobava, como ainda hoje, as povoações de Assequins, Bolfear, Borralha e Paredes, sendo os respectivos casais enumerados nas inquirições. Interessante é notar que, em 1220, Agada não era ainda nome de povoação, mas sim e apenas nome de uma freguesia que abarcava grosso modo a metade oriental da ribeira do Águeda ${ }^{20}$. A povoação principal nesta freguesia, com 18,5 casais, era Assequins, futura sede de concelho e de capitania-mor. Em 1282, como se vê pela inquirição nesse ano realizada em toda a terra de Vouga, a situação continuava a ser a mesma: na freguesia de Águeda fala-se apenas nos lugares de Assequins e Borralha e as testemunhas são de Assequins.

Portanto, desde o século XI existia no local da actual cidade de Águeda uma igreja da invocação de Santa Eulália que, século e meio depois, nos aparece como sede de uma freguesia extensa. Essa freguesia, como a maior parte das freguesias da região deve ter remota origem. O local da igreja, no entanto, deve ter-se mantido sempre mais ou menos ermo ${ }^{21}$. Se alguns moradores ou casais aí existiam, seriam em

lho de Assequins também mostra que o seu foco inicial (a igreja) ficava na fronteira, ou muito próximo dela. O Casal de Lausato, a que apenas aludem o documento citado e outro ainda anterior (DC 378), não passou de uma propriedade rústica pouco habitada ou mesmo não habitada. Entre a última referência que se lhe conhece (1077) e o início da formação do burgo de Águeda passaram mais de dois séculos, intervalo demasiado longo para que se possa estabelecer um elo de ligação entre ambos. Por outro lado, ainda que tivesse havido continuidade entre o Casal de Lausato e o burgo de Águeda, nem por isso faria grande sentido a suposição do Conde da Borralha de que a igreja de Santa Eulália estaria erecta em cabeça do Casal de Lausato. Na verdade, este pequeno casal nunca poderá ter tido população suficiente para formar uma paróquia. De resto, normalmente as paróquias ou freguesias resultavam do agrupamento de várias vilas rústicas e pequenos casais.

19 Não se deve confundir Santa Eulália de Águeda com Santa Eulália de Aguada de Cima, que também está bem documentada (documentos de 957 (DC 73) e 1132 (DP 123)).

20 Caso similar é o de Vouga, nome que em 1220 se dava à freguesia com sede na igreja de Santa Maria de Lamas, mas que não se aplicava a nenhuma povoação em particular. Só mais tarde o lugar designado nas inquirições de 1220 como Rua de Vouga passou a ser conhecido como burgo de Vouga e depois como vila de Vouga.

21 Não era invulgar situarem-se as igrejas em locais ermos. A igreja de São Vicente de Sangalhos ficava fora do corpo desta vila. A igreja de São Pedro de Avelãs de Cima ainda hoje está completamente separada da povoação de Avelãs de Cima. 
número desprezável, já que a documentação até finais do século XIII não dá deles qualquer notícia.

Em finais do século XII ou princípios do seguinte, como referi, a estrada mourisca foi desviada para a margem direita do Cértima. Provavelmente, a ideia terá sido, desde logo, rectificar todo o traçado entre o Marnel e Coimbra e construir uma ponte sobre o rio Águeda. Sabe-se que essa ponte, tal como a do Vouga, andou em construção por toda a segunda metade do século XIII (Sousa BAPTISTA, 1947; SEABra Lopes, 1994b). Só com a conclusão da ponte se terá começado, finalmente, a formar um povoado de vulto junto à igreja de Santa Eulália. Isso terá acontecido por finais do século XIII ou inícios do seguinte. Porém, na documentação do século XIV não se encontrou, até ao momento, qualquer referência ao aglomerado populacional que foi conhecido por Águeda a partir do século XV.

Finalmente, Águeda aparece num documento de 1427 em que se enumeram as povoações que tinham obrigação de ter besteiros do conto (Milenário, doc. 85), sinal de considerável promoção. Nesta época a povoação de Águeda era frequentemente designada por burgo de Águeda. Assim aconteceu, por exemplo, num documento de 1432 sobre as azenhas da Borralha e numa carta de perdão passada por Dom Afonso $\mathrm{V}$ em 1440 (Conde DA Borralha, 1932-39, III, p. 171; V, p. 231). Em 1449 já ali existia uma albergaria, a qual em 1481 era considerada antiga \{Idem, VII, p. 120). É natural, pois, que a fundação da albergaria seja pouco posterior à construção da ponte.

Em 1527, como se vê pelo cadastro de população nesse ano realizado, a chamada aldeia de Agueda era já uma das maiores povoações do Baixo Vouga ${ }^{22}$. Na época moderna, o lugar de Águeda era suficientemente vistoso para que fosse verosímil, aos olhos de muitos dos nossos humanistas, ter sido ali a cidade romana de Emínio.

Do elenco de povoações da estrada coimbrã, três receberam nos séculos XIII a XV a designação de burgo: Vouga, Águeda e Avelãs do Caminho. Ora, segundo Viterbo, um burgo era normalmente um arra-

22 Tinha 80 vizinhos incluindo o lugar do Casainho (BRAAMCAMP FrEIRE, 1908). Só Aveiro (894 vizinhos), Esgueira (175), Vagos (100) e Angeja (95) eram maiores. Agueda tinha, pois, ultrapassado todas as povoações que nos séculos XII e XIII eram dominantes na região. Ois da Ribeira, que tinha sido uma das maiores, estagnara, tendo em 1527 apenas 31 vizinhos. Recardães tinha 36 vizinhos, Assequins tinha 25 e Sangalhos tinha 41 vizinhos. 
balde ou lugar pequeno, de fundação recente, situado junto a uma cidade ou vila mais antiga ou junto a um mosteiro ou catedral 0 , s.v. 'burgo', II, p. 49). Aquelas três povoações enquadram-se perfeitamente neste perfil. O burgo de Vouga surgiu como arrabalde da civitas Marnel e aparece referenciado pela primeira vez num documento de 1258 (Seabra Lopes, 1996a). Avelãs do Caminho, que aparece como burgo num documento de 1364 (BRanquinho De CaRvalho, 1950, p. 16-17), era também uma terra nova, no limite de Sangalhos. A transferência do paço real de Sangalhos para Avelãs, se deve, segundo penso, o desenvolvimento desta última. Águeda é o exemplo acabado da povoação nova, subitamente importante. Foi também um burgo porque se desenvolveu em redor da velha igreja de Santa Eulália.

Outro exemplo da promoção de certas povoações, graças à passagem da estrada coimbrã, é a obrigação em que algumas estavam de ter besteiros. O besteiro era um soldado que usava como arma a besta. Como a conservação destas armas implicava despesas, os besteiros eram tirados dos indivíduos que tinham um certo rendimento. Em 1427 e na área do actual distrito de Aveiro, apenas cinco povoações tinham esta obrigação (Milenário, doc. 85). Uma delas era a vila de Aveiro. As outras quatro todas se situavam junto à estrada: Avelãs do Caminho, Águeda, Vouga e Arrifana.

No percurso da estrada coimbrã entre o Mamei e Coimbra, Aguada de Baixo é a única povoação cuja existência se regista antes da reconquista definitiva de Coimbra. De facto, esta vila, onde já existia a igreja de São Martinho, foi minuciosamente demarcada em 957 (DC 73). Avelãs de Baixo, mais tarde chamada Avelãs do Caminho, aparece referenciada pela primeira vez nas confrontações de Aguada de Baixo incluídas na carta de couto de Barró de 1132 (DR 123).

Todas as outras povoações da estrada coimbrã são já posteriores à construção da estrada coimbrã e consequente abandono da antiga estrada mourisca. A moderna cidade de Águeda começa a formar-se após a conclusão da ponte, em finais do século XIII ou princípios do seguinte. Na margem sul do rio Águeda forma-se a povoação de Sardão, onde os viajantes costumavam pernoitar, a qual viria a ser sede de um minúsculo concelho. A norte de Águeda, a actual vila de Mourisca do Vouga, como o topónimo indica, formou-se junto à estrada mourisca. No entanto, é tão recente a sua formação que nem o cadastro de população de 1527 a refere. 
A Mealhada, hoje também sede de concelho, é outra povoação que surgiu e se desenvolveu no século XIII, certamente em consequência da mudança do traçado da estrada da margem esquerda para a margem direita do Cértima. A primeira referência que se conhece à Mealhada data de 1288 (Branquinho DE CARvalho, 1950). Tal como Agueda, também a Mealhada só foi elevada a sede de concelho após a reforma liberal. A freguesia da Mealhada só há poucos anos foi criada. A pouca antiguidade da Mealhada, terra da estrada coimbrã, contrasta com a origem romana das vizinhas povoações da outra margem do Cértima, incluindo Vimieira, Casal Comba, Antes, Sepins e Murtede.

A organização administrativa e paroquial característica do Antigo Regime estabilizou em época recuada, em plena Idade Média, e poucas alterações sofreu até ao Liberalismo. Localidades perfeitamente decadentes mantinham-se como sedes paroquiais, concelhias e militares. A histórica povoação de Espinhei, por exemplo, era, desde longa data, sede de uma das mais extensas paróquias da região, abrangendo terras desde Oronhe e Casal de Álvaro, na margem norte do Águeda, até Oiã, já na margem ocidental do Cértima. Com o afastamento da estrada coimbrã mais para o interior, Espinhei estagnou. Em contrapartida, a estrada Avelãs-Aveiro, aberta em data incerta, proporcionou grande desenvolvimento a Oiã, que tem hoje a categoria de vila. Em 1798, o contraste era já tão notório que o pároco de Espinhei, seduzido pelos rendimentos do curato de Oiã, decidiu mudar-se para ali de armas e bagagens, indo contra a vontade expressa do bispo (МотА, 1991, p. 21-22).

A reforma administrativa desencadeada após a revolução liberal veio, finalmente, reorganizar o espaço em torno das povoações que apresentavam maior vitalidade. $\mathrm{Na}$ sua grande maioria, os antigos concelhos foram dissolvidos. O espaço cortado pelos vários itinerários Coimbra-Mamel a que me tenho referido está hoje organizado em três concelhos. As respectivas sedes (Águeda, Anadia e Mealhada) situam-se na vizinhança da estrada nacional, correspondente à antiga estrada coimbrã.

$\mathrm{Na}$ região mais a ocidente, atravessada pelo itinerário romano e pela estrada mourisca, foi mais difícil o estabelecimento de sedes concelhias após a reforma liberal. São Lourenço do Bairro chegou a ser sede de concelho entre 1836 e 1853 (Rodrigues, 1959, p. 80). O concelho de Oliveira do Bairro foi também criado em 1836. No entanto, toda esta região da margem ocidental do Cértima estava algo deprimida, decadente mesmo. Em finais do século não havia, em todo 
o concelho de Oliveira do Bairro, um único bacharel em leis (МотA, 1997, p. 87), argumento que se utilizava em favor da sua extinção. Este concelho foi, com efeito, extinto uma primeira vez em 1867, sendo reconstituído passado um ano, e voltou a ser extinto em 1895 e novamente criado em 1898. A decadência das povoações da margem ocidental do Cértima foi atenuada pela passagem do caminho-de-ferro a partir de meados do século XIX. A metade ocidental da ribeira do Águeda, outrora a mais progressiva, é actualmente das mais atrasadas.

Em resumo, poderemos dizer que o itinerário ocidental e a sua variante, conhecida como estrada mourisca no século XII, estruturaram o povoamento mais antigo da região. No princípio da monarquia eram dominantes povoações como Óis da Ribeira, Espinhei, Recardães, Sangalhos e Horta. A abertura da estrada coimbrã e a construção da ponte do rio Águeda provocaram a deslocação do eixo do povoamento mais para o interior. Surgem então Águeda, Mealhada, Mourisca do Vouga, Avelãs do Caminho, Sardão, São João da Azenha e Malaposta. Outras, como Anadia, Aguim, Assequins e Borralha ganharam um novo impulso. Se, no século XIII, os cavaleiros-vilões se concentravam especialmente a ocidente, no século XIX a elite regional habitava já na vizinhança da estrada coimbrã, agora conhecida como estrada real.

\section{As mansiones entre Emínio e Cale}

A caracterização de uma estrada inclui não só a identificação do seu traçado mas também a localização das estações viárias (ChevaLIER, 1972, p. 213-217), que podiam ser de três tipos: stationes, mutationes e mansiones. As stationes eram, tipicamente, postos policiais (com o objectivo de garantir a segurança dos viajantes) ou aduaneiros. As mutationes eram locais para descanso e alimentação dos viajantes bem como para descanso ou mesmo muda dos animais. Finalmente, as mansiones eram locais de pernoita, destinadas a apoiar as deslocações dos altos funcionários e do próprio imperador. As diversas mansiones de urna estrada ficavam espaçadas a distâncias que o viajante legionário percorreria num dia e que oscilavam entre 30 e 36 milhas. As mutationes eram em maior número, como é lógico. Em terreno plano haveria três mutationes por cada mansio, o que dá um intervalo de 10 a 12 milhas entre mutationes consecutivas. Em terreno montanhoso e/ou de altitude, esse intervalo podia reduzir-se até 7 milhas. 
As mansiones e mutationes da estrada situadas entre Mondego e Douro certamente foram determinadas pela distância que separava os dois grandes centros viais mais próximos: Conímbriga e Brácara. Segundo o Itinerário de Antonino, a estrada entre Conímbriga e Brácara passava sucessivamente por Talábriga (Mamel), Lancóbriga (Fiães) e Cale (Porto/Gaia). A distância que o Itinerário indica para o segmento Talábriga-Lancóbriga não pode estar correcta (SEABRA LOPES, 1995, 1996a, 1997a). Felizmente, o confronto com a Geografia de Ptolomeu permite corrigi-la (SEABRA LOPES, 1996b, 1997bc). As distâncias correctas, em milhas ${ }^{23}$, são apresentadas na Tabela IX.

TABELA IX — Distâncias entre Conímbriga e Brácara (em milhas)

\begin{tabular}{lc}
\hline Conímbriga & \\
Emínio & 10 \\
Talábriga & 40 \\
Lancóbriga & 30 \\
Cale & 13 \\
Brácara & 35 \\
Total & 128 \\
\hline
\end{tabular}

Nitidamente, as povoações situadas ao longo da estrada Olisipo-Brácara e mencionadas no Itinerário de Antonino quase só por coincidência são também estações viárias no sentido que acabei de descrever. Com efeito, as distâncias entre localidades vizinhas variavam, considerando já as correcções resultantes do confronto com a Geografia de Ptolomeu, entre as 10 milhas do segmento Conímbriga-Emínio e as 41 milhas do segmento Sélio-Conímbriga (SEABRA LOPES, 1996C; 1997b). O critério em que se baseou a selecção das localidades a figurar no itinerário parece ter sido o da importância dessas localidades, nomeadamente como sedes territoriais.

Sendo a distância total entre Conímbriga e Brácara de 128 milhas, o percurso divide-se, naturalmente, em quatro jornadas. Conímbriga e Brácara teriam com toda a certeza mansiones. Cale, a 35 milhas de Brácara, teria também uma mansio. 1971, p. 36). 
As restantes 93 milhas obrigam à existência de duas mansiones entre Conímbriga e Cale, ficando a jornada média em 31 milhas. A localização dos paços reais da estrada coimbrã na Idade Média dá pistas seguras sobre a localização das mansiones da estrada romana. Com efeito, no início do século XIII havia dois paços entre Porto e Coimbra, um em Figueiredo d'el Rei e o outro em Avelãs do Caminho (SEABRA LOPES, 1994b). Ficava o de Figueiredo a cerca de 28 milhas do Porto e a cerca de 27 milhas de Avelãs. No entanto, o paço de Avelãs ficava a apenas 21 milhas de Coimbra, distância claramente insuficiente para uma jornada. A localização destes dois paços é tanto mais estranha quanto se sabe que os viajantes costumavam passar a noite na zona da ribeira do Águeda e na zona de Oliveira de Azeméis. Assim era já no século XII, conforme testemunho de Edrizi (LOPES, 1911).

No entanto, se estes dois paços reais forem considerados como sobrevivências das mansiones romanas, tudo se torna mais claro: com efeito, Avelãs do Caminho fica a 31 milhas de Conímbriga. A primeira mansio a norte de Conímbriga ficaria, pois, próxima de Avelãs, muito provavelmente em Sangalhos, e a segunda ficaria próxima de Figueiredo, talvez em Ul.

\section{O traçado da estrada Emínio-Talábriga-Cale}

Em seguida, apresenta-se com mais pormenor a reconstituição do traçado da estrada romana entre Emínio e Cale. Entre Emínio e Talábriga a estrada romana seguiria o itinerário ocidental acima descrito. A norte do Vouga a estrada quase decalcava a estrada mourisca. Além das mansiones, sugiro também a localização das mutationes e de duas stationes. As distâncias apresentadas foram calculadas sobre as cartas militares da região à escala 1:25000 24 .

Ponte de Coimbra $\longrightarrow$ Vimieira [12,4 mp]: Entre Coimbra e Vimieira, o viajante passaria sucessivamente pelos lugares de Pedrulha, Adémia de Baixo, Fornos, Cioga, Treixomil, Adões, Sargento Mor,

${ }^{24}$ Sempre que existem caminhos ou estradas a ligar as povoações, medi as distâncias ao longo desses caminhos. Havendo vários caminhos alternativos, escolhi o mais direito e menos íngreme. Nos poucos casos em que não há caminhos visíveis no mapa, procurei caminhos sem continuação que estivessem em alinhamento e que pudessem ter formado, em outro tempo, um caminho de ligação.

Conímbriga, 39 (2000) 191-258 
Carquejo, Mala e Lendiosa. Até época recente, a estrada real seguiu de perto o traçado da estrada romana, dele divergindo apenas no pequeno lugar do Carquejo, onde tomava a direcção da Mealhada. $\mathrm{Na}$ Idade Média, a estrada que ligava Coimbra ao Norte do país era conhecida por strada de Viminaria. A maior parte das povoações referidas são anteriores à nacionalidade. A estação arqueológica romana da Vimieira é bem conhecida. Muito perto dali, embora na margem direita do Cértima, apareceu o marco da milha XII da estrada romana (ALMEIDA, 1956), o qual deveria marcar o fim do território de Emínio e a entrada no de Talábriga (SEABRA LoPes, 1995; 1996a). Tal como sugere MANTAS (1996, p. 809), deveria situar-se nas imediações da Vimeira uma mutatio da estrada romana. A este equipamento se juntaria uma statio para controlo da fronteira territorial.

Vimieira -» Sangalhos do Paço [11,6 mp]: A estrada continua agora pela margem esquerda do Cértima, onde os afluentes são mais pequenos e em menor número, tornando-se por isso mais fácil o trânsito. Logo a seguir à Vimieira, a estrada começa a afastar-se do curso do Cértima, procurando pontos de passagem mais favoráveis nos três principais afluentes desta zona, os ribeiros de Murtede, Ventosa e São Lourenço. Assim, a estrada romana seguiria da Vimeira para Casal Comba, Antes, Ventosa do Bairro (onde se documenta a estrada velha coimbrã em 1288, como referi), Arinhos, Horta (a primitiva sede do couto de Aguim), Óis do Bairro, Lezírias, São Mateus e Cabeço de Mogofores (onde se documenta a passagem da estrada mourisca no século XII, também conhecida como estrada velha no início do século seguinte). Diversas destas povoações são, desde tempos remotos, sedes paroquiais e algumas foram sedes concelhias no Antigo Regime. A estrada continuaria depois por Sá, em direcção a Sangalhos. Aqui se localizaria, pelas razões já apontadas, a primeira mansio a norte de Conímbriga. A distância entre Conímbriga e Sangalhos do Paço pelo itinerário descrito é de cerca de 34 milhas.

A povoação de Sangalhos, situada numa alta colina da margem ocidental do Cértima e precisamente no limite da navegabilidade deste rio, foi sempre uma povoação bipolar. Já as inquirições de 1220 aludiam aos dois polos: "villa de Sancto Galios et de alio Sancto Galios...» (Milenário, doc. 33, p. 65). A vila de Sangalhos propriamente dita, tradicionalmente denominada Sangalhos do Paço, ficava sobranceira ao rio. O outro polo, mais pequeno, desenvolveu-se em torno da igreja de 
São Vicente, situada mais longe do rio, no ponto mais alto da colina. Segundo o foral manuelino deste concelho, Sangalhos do Paço estava organizada desde o século XIII em 15,5 casais e Sangalhos da Igreja em 7 casais. O topónimo Paço, que continua em utilização corrente, é um indicio importante da passagem da estrada mourisca nesta zona. Como já foi referido, no século XII, Sangalhos deu o nome a um dos mais famosos alqueires portugueses. Para a divulgação do alqueire sangalhês muito deve ter contribuído a passagem da estrada mourisca.

Diversos autores têm notado a grande densidade de vestígios romanos na margem esquerda do Cértima (Rodrigues, 1959, p. 9-16; Saa, 1960, p. 175-177). Perto de Vimieira, em Casal Comba, Sepins, Antes, Ventosa, Arinhos, Horta, Ois e Mogofores têm sido encontrados vestígios da romanização, alguns significativos. Todos estes vestígios se situam ao longo do itinerário descrito e explicam-se muito melhor se este itinerário corresponder, de facto, ao traçado da estrada romana. A ara votiva encontrada em Murtede em 1957 (Rodrigues, 1959), com uma forma essencialmente cilíndrica, a lembrar um miliário, e dedicada por C. Fabius, cujo cognomen era Viator, portanto alguém ligado às vias, poderá estar relacionada com a estrada, como sugeriu Encarnação (1996). Nesse caso, ela será também um documento da passagem da estrada pela margem esquerda do Cértima.

Em Sangalhos têm aparecido também bastantes vestígios da romnização, quer junto à igreja de São Vicente, quer no sítio das Sortes, situado ao fundo da colina de Sangalhos do Paço. O sítio das Sortes ainda não foi escavado sistematicamente. No entanto, há por ali tegulce em profusão. Uma pequena escavação, efectuada por um particular (Malheiro, 1997), fez aparecer tijolo de parede, um tijolo de coluna, cerâmica caseira, um peso de tear e uma pequena figura humana, em terracota, muito interessante mas incompleta (Figura 9). De períodos anteriores apareceram machados de pedra, artefactos em silex e outro peso de tear, comprovando-se assim a remota ocupação do local. Na zona envolvente apareceram várias mós manuárias. Particularmente interessante para o problema das estradas parece ser a abundância de escória de ferro e de bronze no mesmo local, o que leva a supor a existência de uma ferraria. A minha hipótese é que essa ferraria serviria para apoio do trânsito (troca de ferraduras, etc.). Nas Sortes se situaria provavelmente uma mutatio, em relação directa com a mansio situada no topo da colina ${ }^{25}$. Seria a terceira a contar de Conímbriga.

25 Este obliterado sítio das Sortes desempenharia, portanto, um papel seme- 
Sangalhos do Paço -») Travassô [10,5 mp]: A estrada descia agora a colina, passando junto às Sortes, e continuava por Murta e Cereal. Neste ponto cruzava-se o Cértima para a margem direita e, subindo a encosta, logo se alcançava Barro, que foi sede de concelho, de couto (que englobava Aguada de Baixo, na estrada coimbrã) e de paróquia. O alinhamento dos caminhos ainda existentes no terreno, em ambas as margens do rio, documenta claramente este antigo ponto de passagem. A estrada desenhava agora urna pronunciada inflexão para ocidente, na direcção de Óis da Ribeira. Este é um dos melhores pontos para a travessia do Agueda, visto que a largura da várzea se reduz a cerca de $300 \mathrm{~m}$. Aqui a estrada bordejava o antigo braço marinho, onde desaguavam os rios Vouga, Águeda e Cértima. O itinerário afastava-se assim da directriz da estrada mourisca que, na Idade Média, seguiria de Barro para Recardães e Paredes. A romana seguiria por Paradela, Piedade, Quinta do Morangal, Espinhei, Óis, Cabanões e Travassô. Paradela documenta-se logo no século $\mathrm{X}$ e parece ser um testemunho toponímico importante da passagem deste itinerário. $\mathrm{Na}$ Piedade apareceram diversos vestígios romanos, incluindo cerâmica de construção e doméstica e um forno (LADEIRA, 1982, p. 71 e 263; RP 3/62). Paradela, Espinhei, Óis e Travassô aparecem referidos na nossa documentação mais antiga. Espinhei é terra muito histórica, como já tive oportunidade de realçar. Uma das ruas, precisamente a que se dirige a Óis, é toda escavada na pedra.

Em 1220, Óis da Ribeira era sede de um julgado que abrangia quase todos os lugares da ribeira do Águeda e ainda Oliveira do Bairro. No local onde eu penso que o itinerário romano cruzaria o Águeda existe actualmente uma moderna ponte de betão (Figura 10). Antes da sua construção, a travessia fazia-se de barco e não há memória de ali alguma vez ter existido uma ponte de pedra. No entanto, uns $300 \mathrm{~m}$ para ocidente da ponte actual sobrevive o topónimo Ponte Pedrinha (de ponte petrina, i. e. 'ponte de pedra'), que designa terrenos de cultivo. Este facto sugere que ali tenha existido, em época recuada, uma ponte de pedra para a travessia do Águeda. Certo é que este ponto de travessia se documenta desde a Idade Média (Sousa BAPTista, 1959, p. 49 e 52).

lhante ao que desempenhou a povoção de A-dos-Ferreiros, na estrada que ligava o Marnel a Viseu. Também na zona de Freixo de Numão, junto a um excelente segmento de calçada romana, se encontraram, de um lado da estrada, os restos de umas instalações que foram identificadas com uma mutatio e, em frente, do outro lado da estrada, as ruínas de uma ferraria (COIX̃̃o, 1997, p. 81). 
Travasso aparece em vários documentos do século IX, incluindo um dos documentos portugueses mais antigos, do ano de 883 (DC 11). Em Travasso, que é o centro de urna das mais características e concorridas romarias do Centro do país, regista-se a tradição da existência de urna antiga albergaria. Como Travasso fica a 10,5 milhas de Sangalhos do Paço, é natural que se tenha situado aqui urna mutatio da estrada romana.

Travasso -》 Ponte do Marnel [5,1 mp]: A estrada toma agora a direcção do Marnel, onde se situava Talábriga (SEABRA Lopes, 1995; 199óab; 1997a), passando por Fontinha, Segadães, Trofa, Crastovães, Covelas e Pedaçães. A bem documentada estrada romana Viseu-Marnel talvez continuasse até ao povoado romano de Cada, sobrepondo-se assim à estrada Emínio-Talábriga nesta parte do trajecto. Quase todos aqueles lugares aparecem na documentação mais antiga. Segadães foi sede concelhia e paroquial no Antigo Regime.

$\mathrm{Na}$ Trofa, junto ao sitio do Murtório e ao actual Instituto Duarte de Lemos, sobrevive o topónimo Calçada. Suponho que corresponde à Lavoura da Calçada a que se referiu Sousa Baptista (1958, p. 312). Talvez se deva relacionar este topónimo com a estrada mourisca. O itinerário romano passaria junto à igreja da Trofa. Numa das ruas de Pedaçães, existem ou existiram numerosas lajes de pedra que deverão ser restos de calçada (SOUSA BAPTISTA, 1942; RP 3/58). Estas pedras não podem ter pertencido à estrada mourisca porque, segundo vários documentos, esta estrada servia de limite a Pedaçães, não podendo por isso atravessar a povoação. Também interessante é o segmento de estrada escavada na rocha que ainda se pode observar na freguesia de Travassô, entre as Hortinhas e o Mato Crespo (Figura 11). O segmento escavado prolonga-se por $40 \mathrm{~m}$, a largura é de $3 \mathrm{~m}$, sem oscilações, e a profundidade da escavação atinge um máximo de $4 \mathrm{~m}^{26}$. A profundidade dos rodados ou trilhos dos carros, em passagem por ali ao longo séculos, atinge os 30 a $40 \mathrm{~cm}$ (isto observei eu em 1994; últimamente foi coberto de terra, para melhorar as condições de circulação). A distância entre os bordos exteriores dos rodados é de $1,3 \mathrm{~m}$, ou pouco mais. É, pois, igual ao trilho tipicamente desenhado pelos carros romanos (Chevalier, 1972, p. 97). Infelizmente, esta coincidência não constitui considera romana, mas atribui-lhe erradamente a largura de $5 \mathrm{~m}$; por outro lado, situaa na freguesia de Segadães, o que também não está correcto.

Conimbriga, 39 (2000) 191-258 
prova da origem romana deste troço de calçada porque os tradicionais carros de bois, ainda hoje utilizados por alguns camponeses, apresentam aproximadamente aquela mesma distância entre as rodas. De resto, por esta zona passava a muito antiga estrada de ligação da Beira a Aveiro (Sousa BAPTISTA, 1959), facto que complica ainda mais a identificação da origem dos vestígios de estradas. Em todo o caso, esta calçada apresenta características similares às de uma outra existente na encosta de Serém (ver adiante).

A ponte do Marnel (Figura 6), que já existia em 1327 (Chancelaria 1325-1336, doc. 131), é o ponto de referência que adopto para marcar as distâncias de Talábriga a Emínio e a Lancóbriga. Na verdade, é de crer que Talábriga se estendesse a ambas as margens do pequeno rio e, nesse caso, a ponte é o melhor ponto de referência. A distância da ponte de Coimbra à ponte do Marnel, pela estrada que se descreveu, é de cerca de 39,6 milhas, confirmando-se, assim, a indicação de 40 milhas do Itinerário de Antonino. Do ponto de vista do trânsito na estrada Olisipo-Brácara, Talábriga não precisaria de ter mansio e nem sequer mutatio. No entanto, como aqui confluía a estrada romana vinda de Viseu, talvez existisse nas imediações, senão uma mansio, pelo menos uma mutatio.

Ponte do Marnel -» Albergaria-a-Velha [5,5 mp]: Depois de cruzar o Marnel, a estrada logo encontrava um obstáculo maior, o rio Vouga. Não se sabe ao certo onde a estrada mourisca atravessou o rio até ao século XII. Sabe-se apenas que passava a oriente do lugar de Pedaçães e que não passava longe de Albergaria-a-Velha. O mais provável, no entanto, é que a travessia, quer da estrada mourisca, quer da estrada romana, se fizesse no local da ponte medieval. Logo a norte, na Gándara de Serém, existem restos de cerâmica de construção que poderão ser romanos (SOUSA BAPTISTA, 1950, p. 101). Além disso, na encosta de Serém, há vestígios de uma antiga estrada, que RocHA MADAHIL (1941, p. 229) descreveu assim: «O indispensável cruzamento da estrada com o Vouga em nenhum outro ponto se poderia obter tão vantajosamente como no local onde presentemente se faz; e que esta passagem decalca a da antiga via militar Aeminium-Cale (...), demonstra-o à saciedade o extenso troço de estrada antiga, muito provavelmente romana, que ainda hoje se vê cortada na rocha viva $e$ fundamente sulcada por milenário rodado de carros, trepando ao alto de Serém, perfeitamente ao lado da actual, partindo sensivelmente do

Conimbriga, 39 (2000) 191-258 
mesmo ponto do rio». Rocha Madahil não deu as dimensões da via que observou. Nada do que descreveu está hoje visível, pois a via foi aterrada e alargada há poucos anos. No entanto, falei com pessoas que moram ali perto, as quais me disseram que ela era estreita e permitia a passagem de apenas um carro. Portanto, esta antiga calçada seria muito semelhante à que ainda hoje se observa em Travassô. A distância da ponte do Marnel a Albergaria-a-Velha, fazendo passar a estrada pelo local da ponte medieval do Vouga e por Assilhó, era de 5,5 milhas.

A actual vila de Albergaria-a-Velha formou-se em redor de uma albergaria fundada pela rainha D. Teresa, em 1117, dentro dos limites do couto de Assilhó (DR 49). Vê-se, por vários documentos, que esta região era conhecida como região de Meison Frido, Meigon Frio, Mansio Frigida, etc. (Seabra Lopes, 1997a). Na Idade Média, a palavra mansio não tinha já o sentido que lhe davam os Romanos e designava uma simples albergaria. Estava fria porque tinha sido abandonada. Assim, talvez sem o saber, D. Teresa refundou a antiga albergaria. Albergaria-a-Velha fica a 10,6 milhas de Travassô, por isso a albergaria de D. Teresa e a tal mansio frigida devem estar na continuidade de uma mutatio da estrada romana.

Albergaria-a-Velha -» UI [10,0 mp]: A estrada seguiria agora a directriz da estrada mourisca do século XII (SEabra Lopes, 1994b), passando successivamente por Albergaria-a-Nova, Laginhas, Curvai, Figueiredo de Baixo, Figueiredo de Cima, Relva, Damonde e Ul. Na freguesia da Branca há diversos vestígios da época romana, nomeadamente no sítio de Cristelo (Souto, 1942; VAZ, 1982). Baseados num equívoco que passou despercebido até há pouco tempo, grande número de autores tem procurado Talábriga nesta zona.

Fr. Bernardo de Brito diz ter achado no monte de São Julião da Branca um miliário com indicação da milha XII. No entanto, a distância por estrada da Branca ao Mamei (Talábriga) é de cerca de 15 milhas e a distância a Fiães (Lancóbriga) é de cerca de 19,5 milhas. De resto, a existência deste miliário e de uma outra lápide que Brito diz ter encontrado em Ossela não deve passar de invenção deste suspeito autor (Almeida, 1956; Seabra Lopes, 1995).

Embutido numa parede da antiga igreja de Ul apareceu, vai para dois séculos, um miliário com indicação da milha XII, certamente relativa a Lancóbriga (Fiães), bem como um terminus augustalis (Almeida, 1956). Uma vez que a distância de Ul a Fiães por estrada 
(experimentei vários itinerários) não pode ser menos do que 13 milhas, o miliário de U1 foi deslocado de um ponto da estrada situado pelo menos 1 milha para norte de Ul. Em todo o caso, o rio U1 seria a fronteira entre Talábriga e Lancóbriga. Tendo em conta a distância de 10 milhas em relação a Albergaria-a-Velha e de 31,1 milhas em relação a Sangalhos, deveriam localizar-se em Ul a sexta mutatio e a segunda mansio a contar de Conímbriga, hipótese reforçada pela importância dos vestígios encontrados nesta zona. A estes dois equipamentos se juntaría ainda uma statio, para controlar a fronteira entre os dois territorios referidos. Próximo de U1, em Figueiredo de Baixo, se situou, até ao século XIII, um paço de pernoita da familia real, facto que também apoia a localização da segunda mansio nesta zona. O achado do miliário em Ul prova que a estrada mourisca seguia de perto a estrada romana. Por isso, é pouco provável que a estrada romana passasse na Bemposta, como sugere MANTAs (1996, p. 821). Aliás, como já referi acima, a Bemposta foi fundada em meados do século XIII, certamente na sequência da rectificação do traçado da estrada mourisca.

$\mathrm{Ul} \rightarrow$ Arrifana [9,0 mp]: O fragmento de miliário encontrado em Adães levou MANTAS (1996, p. 823-826) a propor um traçado para a estrada romana bastante diferente do da estrada mourisca. Ora, se o miliário da milha XII apareceu deslocado uma ou duas milhas da sua posição inicial, o mesmo poderá ter acontecido ao fragmento de miliário de Adães. O autor baseia-se também num documento de 1145 que situa a povoação de Azevedo em São Vicente de Pereira, «subtus illam stratam mauriscam», concluindo que a própria estrada mourisca passava bastante a ocidente de Oliveira de Azeméis. No entanto, a análise da documentação medieval mostra que a expressão subtus normalmente se aplicava a pontos de referência conhecidos em regiões mais ou menos vastas e não implicava proximidade nem, muito menos, contiguidade entre os sítios a localizar e os pontos de referência. Na verdade, a estrada mourisca passava mais a oriente. Passava em Oliveira de Azeméis, onde, segundo Edrizi (LOPES, 1911), se completava a segunda jornada depois de Coimbra, e também em São João da Madeira27. Parece-

$27 \quad$ O documento mais explícito é de 1142: «uilla quos uocitant Sancti Iohanis de Madeira de illa strata mourisca ata illo ueneiro» (FERNANDES, 1996, doc. XVIII, p. 248). Este documento foi citado anteriormente por Oliveira (1943, p. 56), entre outros autores. A estrada aparece referenciada em vários outros documentos, embora 
-me mais prudente fazer seguir a estrada romana pela directriz da estrada mourisca. Assim, de Ul, a estrada seguia para Oliveira de Azeméis, tocava o extremo ocidental de Lações de Baixo, tocava em seguida o extremo nordeste de Santiago de Riba-Ul, continuava por Carcavelos, Pica, Faria de Baixo, Faria de Cima, São João da Madeira e Arrifana. O topónimo Arrifana deve significar ponto de chegada ou de paragem (SAA, 1960, p. 158, n. 1). Na Arrifana ou próximo, apareceu uma ara (Leite de Vasconcelos, 1913, p. 507). Tal como sugere Mantas (1996, p. 825), deveria situar-se aqui urna mutatio da estrada romana.

Arrifana $\longrightarrow$ Fiães [5,0 mp]: A estrada dirigia-se agora para Fiães, onde se situou Lancóbriga (FerReIra DE Almeida \& SAntos, 1971; MANTAS, 1996). Por essa razão, a estrada romana afasta-se do traçado tradicional da estrada mourisca, seguindo por Malaposta de São Jorge, Airas, Soutelo e Fiães ${ }^{28}$. Tal como Talábriga, também Lancóbriga não teria mutatio nem mansio, a não ser por força de outra estrada, vinda do interior, que ali confluísse. A soma das distâncias desde a ponte do Marnel é de 29,5 milhas, valor que se arredonda para as 30 milhas indicadas, para o segmento Talábriga-Lancóbriga, por um dos códices mais antigos do Itinerário de Antonino e pelo guia seguido por Ptolomeu (SEABra LoPES, 1996b; 1997bc).

Fiães $\longrightarrow$ Carvalhos [7,3 mp]: O traçado da estrada romana continuaria, talvez, por Aldriz, Serzedelo, deixando Crasto à sua direita, depois a igreja de Argoncilhe, Camalhões, Ameal, Vendas Novas e, finalmente, Carvalhos, onde se encontrava com o traçado da estrada mourisca. A meia milha de distância dos Carvalhos fica o arqueológicamente importante castro de Nossa Senhora da Saúde ou Monte Murado, talvez a primitiva capital dos Turdulos Velhos. Com efeito, aqui apareceram duas tesserae hospitales aludindo a esse povo. A zona dos Carvalhos fica a 12,3 milhas de Arrifana e poderá, como também sugere Mantas, ter contido uma mutatio. Neste caso, no entanto, a distância desta mutatio à mansio de Cale fica reduzida a 6,1 milhas, se

sem a qualificação de mourisca, desde 1088 (DC 704; FERnANDES, 1996, docs. I, II, X e XV) (em alguns casos aparece astar em vez de strata).

28 Para alcançar Lancóbriga, o traçado da estrada romana proposto por Mantas desvia-se do da estrada mourisca de forma que parece pouco natural. A estrada romana seguida a mourisca até à povoação de Ferrada, aí desviava-se quase abruptamente para Fiães e depois voltava a encontrar a estrada mourisca em Vergada.

Conimbriga, 39 (2000) 191-258 
adoptamos como ponto de referência o local da travessia do Douro entre Vila Nova de Gaia e o Porto. Uma hipótese alternativa, porventura mais razoável, é procurar a mutatio na zona de Argoncilhe, talvez mesmo junto ao lugar de Camalhões, onde confluía a estrada romana vinda de Viseu. Ali próximo regista-se o topónimo Casinhas, que Sousa (1942) considerou ter interesse arqueológico.

Carvalhos — Travessia Gaia-Porto [6,1 mp]: A estrada dirige-se agora à passagem do Douro, junto à cidade de Cale, que ficava em Gaia ou, segundo as opiniões mais recentes, no Porto (CoElHo Da Silva, 1994; MANTAS, 1996). Seguiria o traçado tradicional da estrada mourisca. Cale, como já referi, devia ter a terceira mansio a contar de Conímbriga. Ficava a 27,3 milhas da anterior (Ul) e a 35 milhas de Brácara.

Na Tabela $X$, apresenta-se o sumário do traçado da estrada romana entre Emínio e Cale, com indicação das estações viárias e distâncias. A distância total (82,5 milhas) está de acordo com a distância total indicada pelo itinerário de Antonino corrigido.

TABELA X - Sumário do traçado da estrada Emínio-Cale

\begin{tabular}{llrr}
\hline Ponte de Coimbra & oppidum Aeminium & & \\
Vimieira & mutatio, statio & 12,4 & \\
Sangalhos & mansio, mutatio & 11,6 & \\
Travassô & mutatio & 10,5 & \multirow{2}{*}{39,640} \\
Ponte do Marnel & oppidum Talabriga & 5,1 & \\
Albergaria-a-Velha & mutatio & 5,5 & \\
Ul & mansio, mutatio, statio & 10,0 \\
Arrifana & mutatio & 9,0 & \\
Fiães & oppidum Lancobriga & 5,0 & $29,5 \longrightarrow 30$ \\
Carvalhos & mutatio $(?)$ & 7,3 & \\
Porto/Gaia & oppidum Cale, mansio, mutatio & 6,1 & $13,4 \longrightarrow 13$ \\
Total (mp) & & 82,5 & 83 \\
\hline
\end{tabular}

10. Resumo histórico e conclusão

Talvez a melhor forna de concluir este trabalho seja apresentar um resumo da história da região estudada, focando especialmente as transformações operadas a nível geomorfológico, viário e do povoamento. 
Quando o oceano estabilizou em níveis próximos dos actuáis, por volta do ano 1000 a. C, a configuração do litoral aveirense apresentava uma pronunciada reentrância que se prolongava desde Espinho até ao Cabo Mondego. Dessa enorme baía partia um braço de mar que atingia a zona de Eirol ou mesmo Ferméntelos. Aí desaguavam independentemente os rios Vouga, Águeda e Cértima. As cotas dos campos do Vouga, na zona do Marnel, e do Águeda seriam muito mais baixas. A zona da ribeira do Águeda estaria talvez sujeita a marés.

Do ponto de vista da ocupação humana, foram chegando em vagas sucessivas povos de raiz indoeuropeia e semita. A região do Vouga, rica em cobre, parece ter desempenhado um papel importante no fornecimento desse metal para as regiões mais setentrionais.

Do ponto vista da circulação e, portanto, do traçado dos principais itinerários, três princípios gerais seriam observados: 1. Evitar as várzeas dos rios; 2. Seguir os vales; 3. Preferir o litoral. E assim que o velho itinerário de ligação do Noroeste peninsular à foz do Tejo seguia sempre o mais possível pelo litoral, apenas se afastando dele quando era necessário evitar os deltas dos rios, como é o caso do Vouga e do Mondego. Este velho caminho, que Plínio seguiu na sua descrição do litoral lusitano, passava sucessivamente pelo Porto, Marnel, Coimbra, São Sebastião do Freixo (Batalha), Abobriz (Óbidos) e Sintra.

Entre a travessia do Vouga, no Marnel, e a travessia do Mondego, em Coimbra, o trânsito tinha que enfrentar a várzea do Águeda que, em todos os tempos, constituiu um importante obstáculo à circulação. Dois itinerários alternativos saltam à vista: um seguia pelo interior, cruzando o Águeda em Assequins; o outro contornava a várzea a ocidente, cruzando o rio Águeda em Óis da Ribeira e tocando neste ponto o extremo do braço marítimo onde também confluíam o Vouga e o Cértima. Este ponto de confluência dos três rios deveria ser muito animado pelas rotas de comércio marítimo e seria, assim, muito habitado. A própria capital da região, Talábriga, ficava muito próxima desta zona de confluência. Pela mesma razão, o itinerário ocidental seria geralmente preferido ao itinerário interior. De resto, isto é mais um exemplo de como os itinerários que tocavam o litoral eram normalmente preferidos. Antes de chegar a Aguada, este itinerário atravessava o Cértima para a margem ocidental, por forma a evitar os rios de Aguada, Avelãs e Arcos e respectivas várzeas.

Os Romanos devem ter aproveitado este itinerário ocidental. Por um lado, a distância por estrada entre Talábriga (Marnel) e Emínio 
(Coimbra) era, segundo o Itinerário de Antonino, de 40 milhas, distância esta que coincide com a distância medida ao longo do itinerário ocidental, sendo bastante diferente das distâncias medidas ao longo do itinerário interior e da estrada coimbrã. Por outro lado, é ao longo do itinerário ocidental que, de longe, encontramos a maior densidade de vestígios romanos. Trata-se de uma cadeia ininterrupta de vestígios que se prolonga de Coimbra até à Piedade (Espinhei).

Entre Conímbriga e Brácara existiriam três mansiones, situándole uma em Sangalhos, outra em Ul e a terceira na zona do Porto. Do ponto de vista do trânsito nesta estrada, Emínio, Talábriga e Lancóbriga não serviriam como mansiones. Tal poderia acontecer, no entanto, devido a outras estradas que confluíssem nestas cidades. Outros itinerários romanos nesta região seriam os seguintes: um ligava Coimbra ao povoado romano de Cacia, estrategicamente situado à entrada do delta do Vouga, passando por Murtede, Ouca, ílhavo e Aveiro; o outro ligava Viseu ao Marnel (esta parte está confirmada por miliários) e do Marnel continuaria por Travassô, Eirol e Eixo até ao povoado romano de Cacia.

Uma excessiva fé no Itinerário de Antonino levou muitos autores a não porem em causa as distâncias indicadas por esta fonte para o percurso entre Emínio e Cale. A verdade é que o Itinerário indica uma distância total de 71 milhas para este percurso, ou seja, apenas 0,5 milhas mais do que a linha recta. Aceitando esta distância, haveria que considerar que a estrada era praticamente rectilínea e, portanto, de excepcional construção. Seria, pois, de esperar que muitos vestígios dela tivessem subsistido até ao presente. A verdade é que poucos vestígios inequívocos da estrada romana se conservam. A calçada de Serém, considerando a sua localização, poderá ter origem romana. No entanto, esta é uma calçada estreita, facto que contraria a imagem de uma grande e bem construída estrada. A correcção da distância Talábriga-Lancóbriga, feita por comparação com a Geografia de Ptolomeu, leva não só a localizar Talábriga no Marnel, mas também a aumentar o comprimento total da estrada em 12 milhas. Desta maneira, cai por terra a imagem da estrada quase rectilínea. Ao contrário, pelo menos no tempo em que as distâncias foram medidas (séculos I a. C. / I d. C.), a estrada romana seria sinuosa e estreita, pouco passando de uma adaptação de velhos caminhos.

$\mathrm{Na}$ Idade Média, a maior densidade do povoamento continuava a registar-se na zona de confluência dos três rios. Globalmente, o povoamento continuava a organizar-se em torno do itinerário ocidental. Isso ficou claramente demonstrado pelo esboço topográfico das igrejas 
e das cavalarias da região do Vouga por volta de 1300. A passagem da estrada mourisca, depois chamada estrada velha, na margem ocidental do Cértima está atestada em três documentos. Quanto à travessia do Agueda, talvez ela se fizesse próximo de Recardães, atendendo à importância com que esta vila nos surge na documentação dos séculos $\mathrm{X}$ e XI. Certas referências a caminhos e estradas apontam para idêntica conclusão. No entanto, Óis da Ribeira, que se situava no centro do povoamento da região e que chegou a ser sede de um extenso julgado, deve ter continuado a ser um ponto de travessia bastante utilizado.

Fundada a monarquia portuguesa, os reis tratam de povoar e organizar o território. Dom Afonso Henriques manda construir a ponte de Coimbra em 1132, ponte esta que demorará mais de século e meio a concluir-se. Dom Sancho I, cognominado de «Rei Povoador», no trono entre 1185 e 1211, terá sido o responsável pela rectificação do traçado da estrada entre o Marnel e Coimbra. A nova estrada, conhecida como estrada coimbrã, passava agora nas proximidades do futuro burgo de Agueda e, mais a sul, seguia pela margem oriental do Cértima. Em 1220 , as mansiones romanas eram representadas pelos paços reais de Avelãs do Caminho e de Figueiredo. Em meados do século XIII, fez-se outra rectificação na zona de Ul. A estrada deixou de passar em Figueiredo e Ul, sendo deslocada mais para o interior. É assim que surge a Bemposta, que rapidamente se transforma em sede do julgado de Figueiredo. O paço real de Figueiredo foi transferido para o Curvai. Por esta época estavam já em construção as pontes do Vouga, do Mamei e do Águeda, que terão sido concluídas em finais deste século ou princípios do século XIV. A ponte de Almeara, que fazia o cruzamento da estrada da Beira com o rio Águeda, também já existia em 1377.

A quase totalidade do povoamento actualmente situado ao longo da estrada coimbrã tem origens posteriores à sua construção. Aguada de Baixo é a grande excepção, estando documentada desde 957. Em 1132 surge-nos Avelãs de Baixo, povoação que viria a albergar o paço real. No século XIV, era já conhecida como burgo de Avelãs de Caminho. Em 1288, surge a primeira referência à Mealhada. Águeda, cuja formação deve ter-se iniciado após a conclusão da ponte, só se documenta a partir do século XV. Também se chamou burgo de Águeda. Mourisca do Vouga, Sardão, São João da Azenha, Malaposta, Vendas da Pedreira são povoações ainda mais recentes.

No século XVII, já se documenta uma outra importante ligação da Beira a Aveiro, a qual cruzava com a estrada coimbrã em Avelãs de

Conimbriga, 39 (2000) 191-258 
Caminho. Na sua versão actual, ela segue da Malaposta por Sangalhos, Oliveira do Bairro, Oiã, Costa do Valado e São Bernardo. Este itinerário deve ser relativamente recente, urna vez que não é visível na estrutura do povoamento antigo. A passagem da Linha do Norte do caminho-de-ferro, a partir do século XIX, veio dar ainda mais vitalidade a este eixo.

Os grandes contrastes entre a estrutura do povoamento medieval e a estrutura do povoamento contemporânea reflectem precisamente as transformações da rede viária que descrevi e ainda as transformações geomorfológicas desta região. $\mathrm{O}$ assoreamento da rede hidrográfica, o recuo da foz do Vouga e a formação da ria de Aveiro transferiram para o litoral o centro do povoamento. E foi assim que, à civitas Marnel medieval, descendente directa da Talábriga romana e sobre ela construída, sucedeu a moderna Aveiro.

\section{Bibliografia}

AlarCÃo, J. (1967; 1970) «On the Westernmost Road of the Roman Empire», Archaeology, vol. 20 (3), p. 174-177; «On the Westernmost Road of the Roman Empire. Part II», Archaeology, vol. 23 (1), p. 44-48.

Alarcão, J. (1988a) Roman Portugal, Aris \& Philips Ltd, Warminster, England.

Alarcão, J. (1988b) O Domínio Romano em Portugal, Publicações Europa-América.

Alarcão, J. (1998) «A Paisagem Romana e Alto-Medieval em Portugal», Conimbriga, $37,89-119$.

Almeida, F. (1956) «Marcos Miliários da Via Romana Aeminium-Cale», O Arqueólogo Português, vol. III (nova série), p. 111-116.

Alveirinho Dias, J. M., A. Rodrigues \& F. Magalhães (1987) «Evolução da Linha da Costa em Portugal desde o Último Máximo Glaciário até à Actualidade: Síntese dos Conhecimentos», Estudos do Quaternário, I, APEQ, p. 56-66.

Alves Pereira, F. (1907) «Geographia Proto-Histórica da Lusitânia. Situação Conjectural de Talábriga», O Arqueólogo Português, vol. 12, p. 129-158.

Amorim Girão, A. (1922) Bada do Vouga. Estudo Geográfico, Imprensa da Universidade, Coimbra.

Azevedo, R. (1933) «O Mosteiro de Lorvão e a Reconquista Cristã», Arquivo Historio de Portugal, vol. I, fase. 4, p. 183-239.

Baptista, J. (1829) Reflexões sobre a Navegação do Rio Vouga, manuscrito datado de 1829 mas que reproduz uma comunicação apresentada à Academia das Ciências em 1820. Transcrito em Reflexões sobre a Navegação do Rio Vouga. 1829, introdução e notas de A. Lúcio Vidal, Estante Editora, Aveiro, 1989, p. 51-65.

Conimbriga, 39 (2000) 191-258 
$\mathrm{BF}=$ Cartulaire de Baio-Ferrado du Monastére de Grijó (Xle-XIIIe Siécles), Robert Durand (ed.), Paris, 1977.

BraAmcamp Freire, A. (1908) «Povoação da Estremadura no XVI século», Archivo Historico Portuguez, vol. VI, p. 241-284.

Branquinho DE Carvalho, J. (1950) «A Antiguidade da Mealhada nas Enciclopédias e nos Documentos», Arquivo do Distrito de Aveiro, Aveiro, p. 213-226.

BrÁs TeIXeIRA, S. L. R. (1994) Dinâmica Morfossedimentar da Ria de Aveiro (Tese de Doutoramento em Geologia, policopiada), Lisboa.

Castelo Branco, F. (1971) «Litoral Português, Evolução do» Dicionário de História de Portugal, Joel Serrão (dir.), Livraria Figueirinhas, Porto, vol. IV, p. 39-43.

CAStro, M. E. (1987) «Trajecto da Via Militar Romana desde a Branca a Fiães da Feira», Actas das I Jornadas de História e Arqueologia do Concelho de Arouca, Arouca, p. 47-52.

Censual - Censual do Cabido da Sé do Porto, Biblioteca Pública Municipal do Porto (ed.), Imprensa Portuguesa, Porto, 1924.

Chancelaria 1325-1336 = Chancelarias Portuguesas. D. Afonso IV. Volume 1 (1325-1336), Centro de Estudos Históricos da Universidade Nova de Lisboa, 1990.

Chevalier, R. (1972) Les Voies Romaines, Lib. Armand Colin, Paris.

Coelho Da Silva, A. (1994) «As Origens do Porto», Historia do Porto, L.A. Oliveira Ramos (dir.), Porto, p. 45-116.

CoIXão, A. N. S. (1997) Um Projecto, a Investigação, a Musealização e um Circuito. Freixo de Numão 1980-1996, ACDR de Freixo de Numão.

CONDE DA BorralHa (1932-1939) I = «Águeda. Subsidios para a sua Historia», Shell News, Aveiro, 31 de Dezembro de 1932, reproduzido em «Águeda (Uma Transcrição Necessária)», Arquivo do Distrito de Aveiro, vol. IV, 1938, p. 309-313; II = «Águeda: Subsídios para a sua História», Arquivo do Distrito de Aveiro, vol. I, 1935, p. 49-56; III = «Águeda ... III», Idem, p. 171-181; IV = «Águeda IV ...», Idem, vol. II, 1936, p. 29-33; V = «Águeda V ...», Idem, p. 29-33; VI = «Águeda VI ...», Idem, vol. Ill, 1937, p. $105-115$ e 281 e segs.; VII = «Águeda VII ... », Idem, vol. V, 1939, p. 119-126.

Correia, F. S. (1944) Origens e Formação das Misericórdias Portuguesas, Lisboa.

Costa Veiga, A. B. (1943) Algumas Estradas Romanas e Medievais. Notas ao Atlas do Vol. I dos Estudos de Historia Militar Portuguesa, Lisboa.

Cruz, L. M. M. (1995) Subsidios para urna Carta Arqueológica da Região da Bairrada, Levantamento arqueológico n. ${ }^{\circ}$ 238, Instituto de Arqueologia, Coimbra.

DC = Portugaliae Monumenta Historica. Diplomata et Chartae, vol. I, Lisboa, 1867$-1873$.

DP/III = Documentos Medievais Portugueses. Documentos Particulares, vol. III. AD.

1101-1115, Rui de Azevedo (ed.), Academia Portuguesa de História, 1940.

DP/IV = Documentos Medievais Portugueses. Documentos Particulares, vol. IV, Rui de Azevedo e Avelino de Jesus da Costa (ed.), Lisboa, 1980. 
DR = Documentos Medievais Portugueses. Documentos Régios, Rui de Azevedo (ed.), Academia Portuguesa de Historia, vol. I, tomos I e II, 1958-1961.

Elucidário $=$ Fr. J. de Santa Rosa de Viterbo, Elucidário das Palavras, Termos e Frases, edição crítica de Mário Fiúza, 2 volumes, 1965-66.

EnCARnaÇão, J. d' (1996), «Recensões bibliográficas», Conimbriga, 35, Coimbra, p. 224-225.

Fernandes, M. A. (1996) S. João da Madeira: Cidade do Trabalho, Câmara Municipal de S. João da Madeira.

Ferreira De Almeida, C. A. \& E. SAntos (1971) «O Castro de Fiães», Revista da Faculdade de Letras da Universidade do Porto. Série de História, vol. II, 1971, p. $147-168$.

Ferreira, O. (1993) Caracterização dos Principais Factores Condicionantes do Balanço Sedimentar e da Evolução da Linha da Costa entre Aveiro e o Cabo Mondego, tese de mestrado, Universidade de Lisboa.

Fortunato De Almeida (1971) «Catálogo de todas as Igrejas, Comendas e Mosteiros que Havia nos Reinos de Portugal e Algarves pelos Anos de 1320 e 1321 com a Lotação de cada uma delas. Ano de 1746», História da Igreja em Portugal, nova edição, vol. 4, Livraria Civilização, Porto, p. 90 e segs.

Granja, H. \& T. A. M. De Groot (1996) «Sea-Level Rise and Neotectonism in a Holocene Coastal Environment at Cortegaça Beach (NW Portugal): A Case Study», Journal of Coastal Research, vol. 12, p. 160-170.

Ladeira, F. D. (1982) Município de Águeda, Ed. do Autor, 2 volumes. Nenhum dos volumes apresenta data de edição, mas o autor informa no volume II, p. 39 e 41, que ambos foram entregues na tipografia em 1982.

Lancastre E TÁvora, L. G. (1983) O Estudo da Sigilografia Medieval Portuguesa, Ministério da Educação.

Leite de Vasconcelos, J. (1913) Religiões da Lusitânia, vol. III, Imprensa Nacional, Lisboa.

LOPEs, D. (1991) Os Árabes nas Obras de Alexandre Herculano, (separata do Boletim da Segunda Classe, Academia das Ciências de Lisboa, vol. 3-4).

Loureiro, A. F. (1874) O Mondego e a Barra da Figueira, Imprensa Nacional, Lisboa.

LP = Livro Preto da Sé de Coimbra, Leontina Ventura e Maria Teresa Veloso (ed.), Avelino de Jesus Costa (dir.), Arquivo da Universidade de Coimbra, 1977-79.

Malheiro, L. (1997) «Sangalhos: Povoação de Origem Romana», Aqua Nativa, Associação Cultural de Anadia, n. ${ }^{\circ}$ 12, p. 44-49.

Mantas, V. (1996) A Rede Viária Romana na Faixa Atlântica entre Lisboa e Braga, Faculdade de Letras da Universidade de Coimbra, Coimbra (Tese de Doutoramento, policopiada).

Mattoso, J., L. Krus \& A. Andrade (1993) A Terra de Santa Maria no Século XIII. Problemas e Documentos, Comissão de Vigilância do Castelo de Santa Maria.

Mendes, H. G. (1974) «Cartografia e Engenharia da Ria e Barra de Aveiro no Ultimo Quartel do Século XVIII», Arquivo do Distrito de Aveiro, vol. XL, p. 184-220 e 241-270.

Conimbriga, 39 (2000) 191-258 
Milenário = Milenário de Aveiro. Colectânea de Documentos Históricos, vol. I, Cámara Municipal de Aveiro.

Morais, A. (1922) «A Mata de Perrães», memoria apresentada ao Instituto Etnológico da Beira em 22 de Fevereiro de 1922. Transcrita por J. S. de Sousa Baptista em «A Pateira de Ferméntelos», Arquivo do Distrito de Aveiro, vol. XI, 1945, p. 250-263.

MotA, A. P. (1991) Oiã: Terras e Gentes, Associação de Jornalistas e Escritores da Bairrada.

MотA, A. P. (1997) Oliveira do Bairro: em Busca da Historia Perdida, Cámara Municipal de Oliveira do Bairro.

Nogueira Gonçalves, A. (1959) Inventário Artístico de Portugal. VI. Distrito de Aveiro. Zona Sul, Academia Nacional de Belas Artes (ed.), Lisboa.

Nogueira GonÇalves, A. (1981) Inventário Artístico de Portugal. X. Distrito de Aveiro. Zona Norte, Academia Nacional de Belas Artes (ed.), Lisboa.

NogueIra Gonçalves, A. (1967) «As Pontes de Mestre Zacarias de Córdova no Século Décimo», Ocidente, vol. LXXII, p. 3-17.

Oliveira, M. (1943) «De Talábriga a Lancóbriga pela Via Militar Romana», Arquivo do Distrito de Aveiro, IX, p. 44-68.

Oliveira, M. (1967) Ovar na Idade Média, Ovar.

Pato, M. S. (1919) A Pàteira de Ferméntelos: Ante-Projecto de Enxugo, Instituto Superior de Agronomia, Lisboa.

Pereira, I. P. \& M. S. Ramos (1778a) Mappa Topográfico da Barra da Cidade de Aveiro, Mapoteca do Instituto Geográfico e Cadastral, mapa n. ${ }^{\circ}$ 309. Mendes (1974, p. 200-204) reproduz o mapa e transcreve as legendas das várias carteias nele incluídas.

Pereira, I. P. \& M. S. Ramos (1778b) Supplemento do Mappa Topográfico da Barra e Rios da Cidade de Aveiro, Arquivo Histórico Militar, caixa 16. Transcrito em Mendes, 1974, p. 205-215.

Ramos, D. (1988) Serafim Soares da Graça: Agueda Antiga. Selecção, Introdução e Notas, Águeda.

Ribeiro, O. (1971) «Povoamento», Dicionário de História de Portugal, Joel Serrão (dir.), vol. VI, 1971, p. 466-485.

RibeIro, O., H. Lautensach \& S. Daveau (1987) Geografia de Portugal, vol. I, Edições João Sá da Costa, Lisboa.

Rocha Madahil, A. G. (1941) «Estação Luso-Romana do Cabeço do Vouga», Arquivo do Distrito de Aveiro, vol. VII, Aveiro, p. 227-258 e 313-369.

Rocha MadahIL, A. G. (1942) «O Rol das Cavalarias do Vouga», Arquivo do Distrito de Aveiro, vol. VIII, p. 153-159.

Rocha Madahil, A. G. (1944) «A Propósito da Visitação do Delegado Episcopal à Igreja de Sangalhos em 1587», Arquivo do Distrito de Aveiro, vol. X, p. 132-140 .

Rodrigues, J. (1959) O Couto de Aguim. Subsídios para a Sua História, Cisial, Anadia. SAA, M. $(1959 ; 1960)$ As Grandes Vias da Lusitânia, t. II e III.

Santa Maria, Fr. A. (1721) Santuário Mariano e História das Imagens Milagrosas

Conimbriga, 39 (2000) 191-258 
de Nossa Senhora, Tomo VII, Oficina de Antonio Pedroso Galvão, Lisboa Ocidental.

Seabra Lopes, L. (1994a) «A Propósito da Ponte do Casal da Rúa. Contributo para o Estudos das Vias Antigas no Concelho de Anadia», Aqua Nativa, Associação Cultural de Anadia, n. ${ }^{\circ}$ 7, p. 51-56.

Seabra Lopes, L. (1994b) «De Portugal a Coimbra pela Estrada Mourisca», Estudos Aveirenses, n. ${ }^{\circ}$ 3, Aveiro, p. 97-100.

SEAbra LOPES, L. (1995) «Talábriga: Situação e Limites Aproximados», Portvgalia, nova série, vol. XVI, Instituto de Arqueologia, Porto, p. 331-343.

Seabra Lopes, L. (1996a) «Talábriga e as Origens da Terra de Vouga», Beira Alta, vol. LV, 1-2, Assembleia Distrital de Viseu, p. 169-187.

Seabra Lopes, L. (1996b) «As Coordenadas de Talábriga», Estudos Aveirenses, n. ${ }^{\circ}$ 6-7, Aveiro, p. 229-244 (ainda em publicação).

SeAbra LOPES, L. (1997a) «O Problema da Localização de Talábriga», Munda, n. ${ }^{\circ}$ 34, Grupo de Arqueologia e Arte do Centro, Coimbra, p. 57-60.

Seabra Lopes, L. (1997b) Correcções ao Itinerário de Antonino entre Olissipo e Brácara Augusta, São João da Azenha.

SEABRA LoPes, L. (1997C) «Itinerários da Estrada Olisipo-Brácara: Contributo para o Estudo da Hispánia de Ptolomeu», O Arqueólogo Português, série IV, vol. 13/15 (1995-1997) [volume comemorativo do centenário da revista], p. 313$-346$.

Silva, A. M. (1994) Proto-Historia e Romanização no Entre Douro e Vouga Litoral: Elementos para uma avaliação crítica, dissertação de mestrado, Faculdade de Letras, Porto.

Silveira, J. (1914) «O Cértima e a Pateira», Jornal de Anadia, 6 de Setembro de 1913/21 de Novembro de 1914. Reproduzido em Estudos de Toponímia da Bairrada e Outras Notas, A. Mota (ed.), Liv. Figueirinhas, Porto, 1993, p. $39-70$.

SILVEIRA, J. (1911) «O Crasto de Anadia (Estação Lusitânica)», Jornal de Anadia, 12-26 de Agosto. Reproduzido em Estudos de Toponímia da Bairrada e Outras Notas, Arsénio Mota (ed.), Livraria Figueirinhas, Porto, 1993, p. 71-77.

SilveirA, J. (1943) «Inquirição na Terra de Vouga em 1282», Arquivo do Distrito de Aveiro, vol. IX, p. 81-88.

Sousa Baptista, A. S. (1947) «Pontes do Vouga e do Marnel», Arquivo do Distrito de Aveiro, vol. XIII, Aveiro, p. 81-85

Sousa Baptista, A. S. (1948) «Estradas Romanas no Concelho de Águeda», Arquivo do Distrito de Aveiro, vol. XIV, p. 3-22.

Sousa BAPTISTA, A. S. (1950a) «Considerações sobre a Cidade Luso-Romana de Vacca, o Julgado e o Burgo de Vouga», Arquivo do Distrito de Aveiro, vol. XVI, p. 81-117.

Sousa BAPTISTA, A. S. (1950b) «Cavalarias do Vouga», Arquivo do Distrito de Aveiro, vol. XVI, Aveiro, p. 175-188.

Sousa BaPtista, A. S. (1958) «Ponte do Marnel», Arquivo do Distrito de Aveiro, vol. XXIV, Aveiro, p. 311-316.

Conimbriga, 39 (2000) 191-258 
Sousa BaPTista, A. S. (1959) «Ponte de Almeara», Arquivo do Distrito de Aveiro, vol. XXV, Aveiro, p. 47-54.

Sousa BAPTISTA, J. S. (1942) «Vestígios de Vias Romanas no Concelho de Águeda», Arquivo do Distrito de Aveiro, vol. VIII, Aveiro, p. 93-98.

Sousa, A. (1942) «Antiguidades do Concelho da Feira», Arquivo do Distrito de Aveiro, vol. 8, p. 129-152 e 206-221.

Souto, A. (1942) «Romanização no Baixo Vouga», Trabalhos da Sociedade Portuguesa de Antropologia e Etnologia, IX, 4, p. 283-328.

TeOdoro de Matos, A. (1980) Transportes e Comunicações em Portugal, Açores e Madeira (1750-1850), Ponta Delgada.

Um Flaviense (1839) Taboa Geografico-Estatística Luzitana, Porto. TJm Flaviense' é pseudónimo de Francisco dos Prazeres Maranhão.

VAZ, J. L. I. (1982) «Primeira Campanha de Escavações em Cristelo da Branca», Boletim ADERAVE, 6, p. 26-30; 7, p. 2-14. 


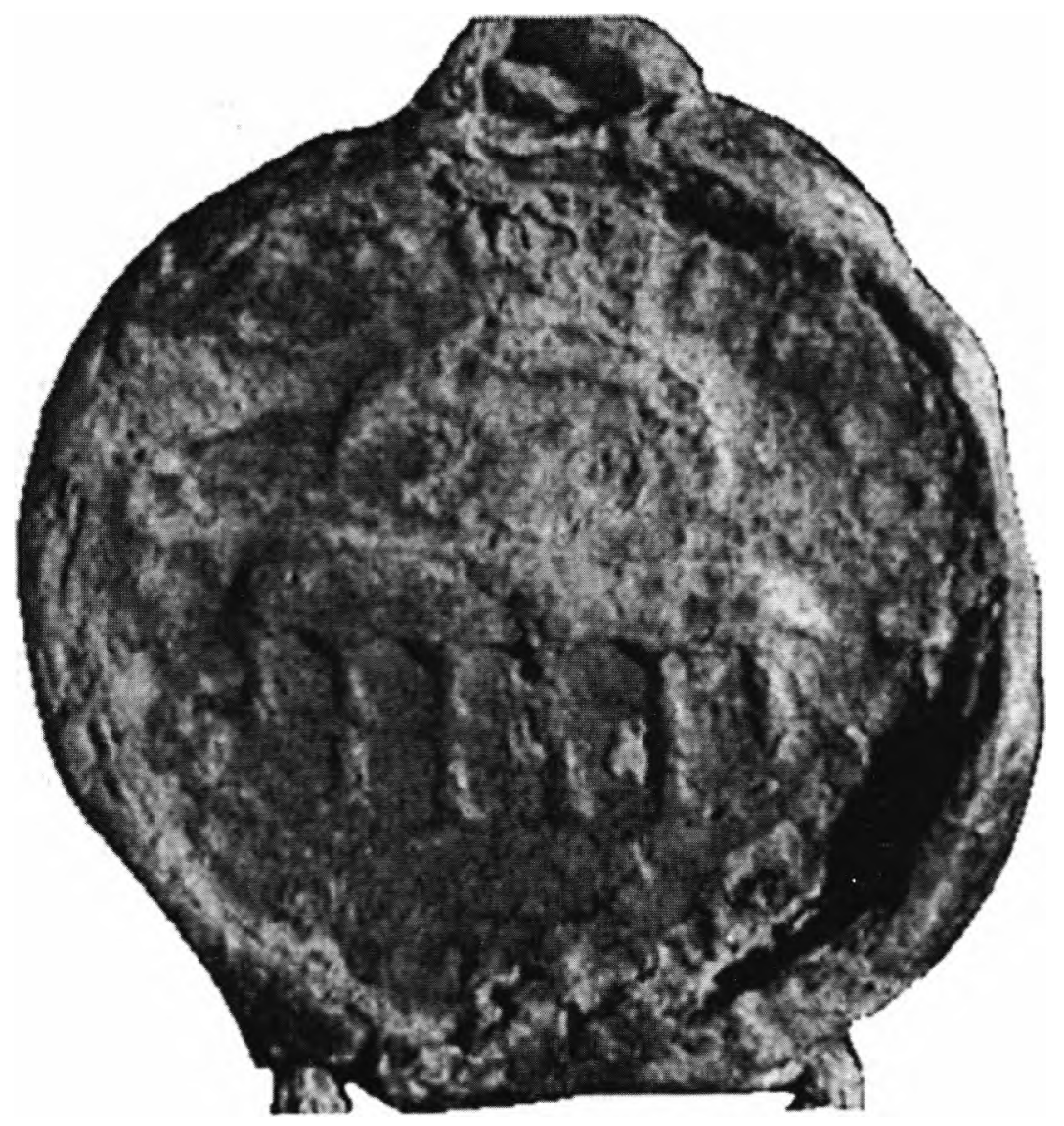

FigURA 1 - Selo da terra de Vouga, pendente de um documento de 1310 e tendo por figura central urna ponte de cinco arcos (ANTT, Cabido da Sé de Coimbra, 2. ${ }^{a}$ incorporação, maço 9ID, n. ${ }^{\circ} 4398$ ). 


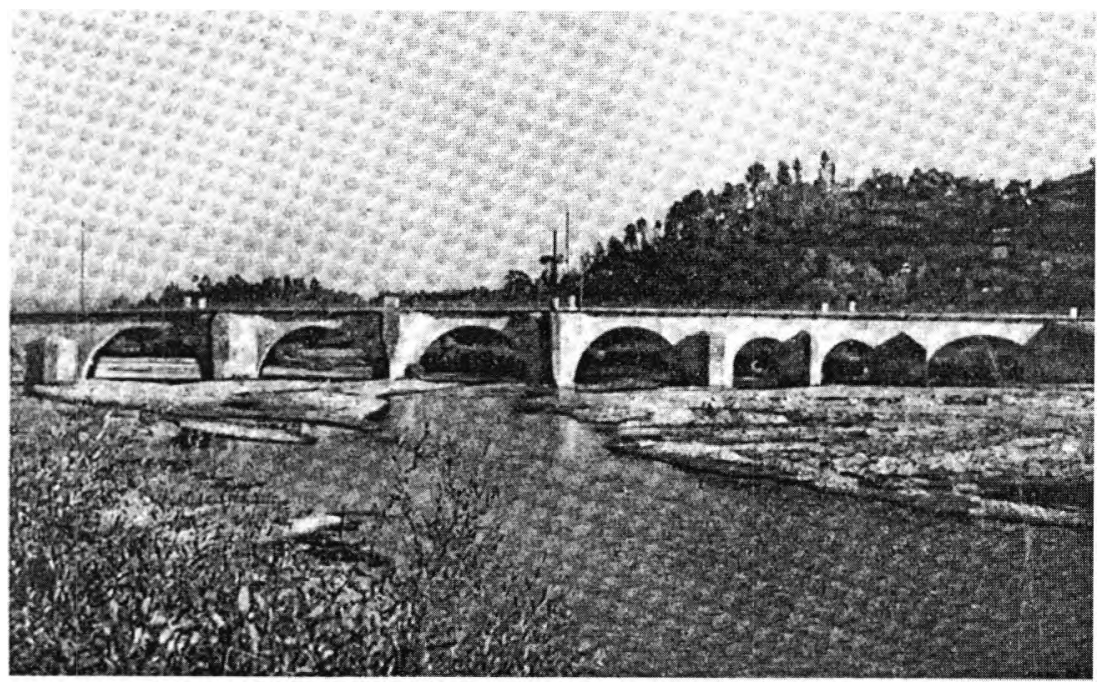

FIGURA 2 - O estado de assoreamento do rio Vouga na zona da ponte na década de 1950. Reproduzido de NoGueIRA Gonçalves, 1959, estampa 49

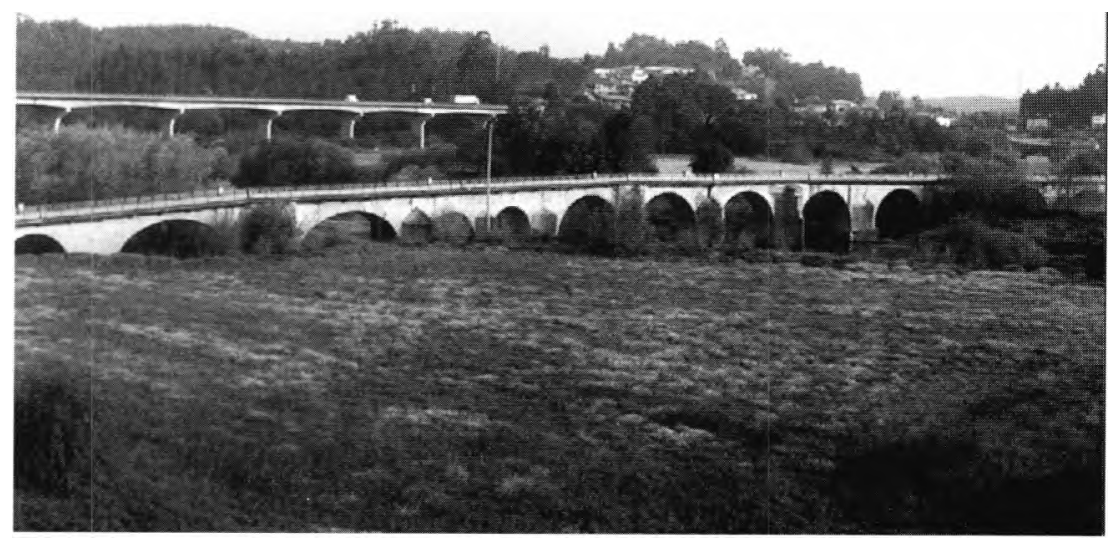

FIGURA 3 - Vista actual da ponte setecentista do Vouga (ao fundo a ponte moderna e a encosta de Serém) 


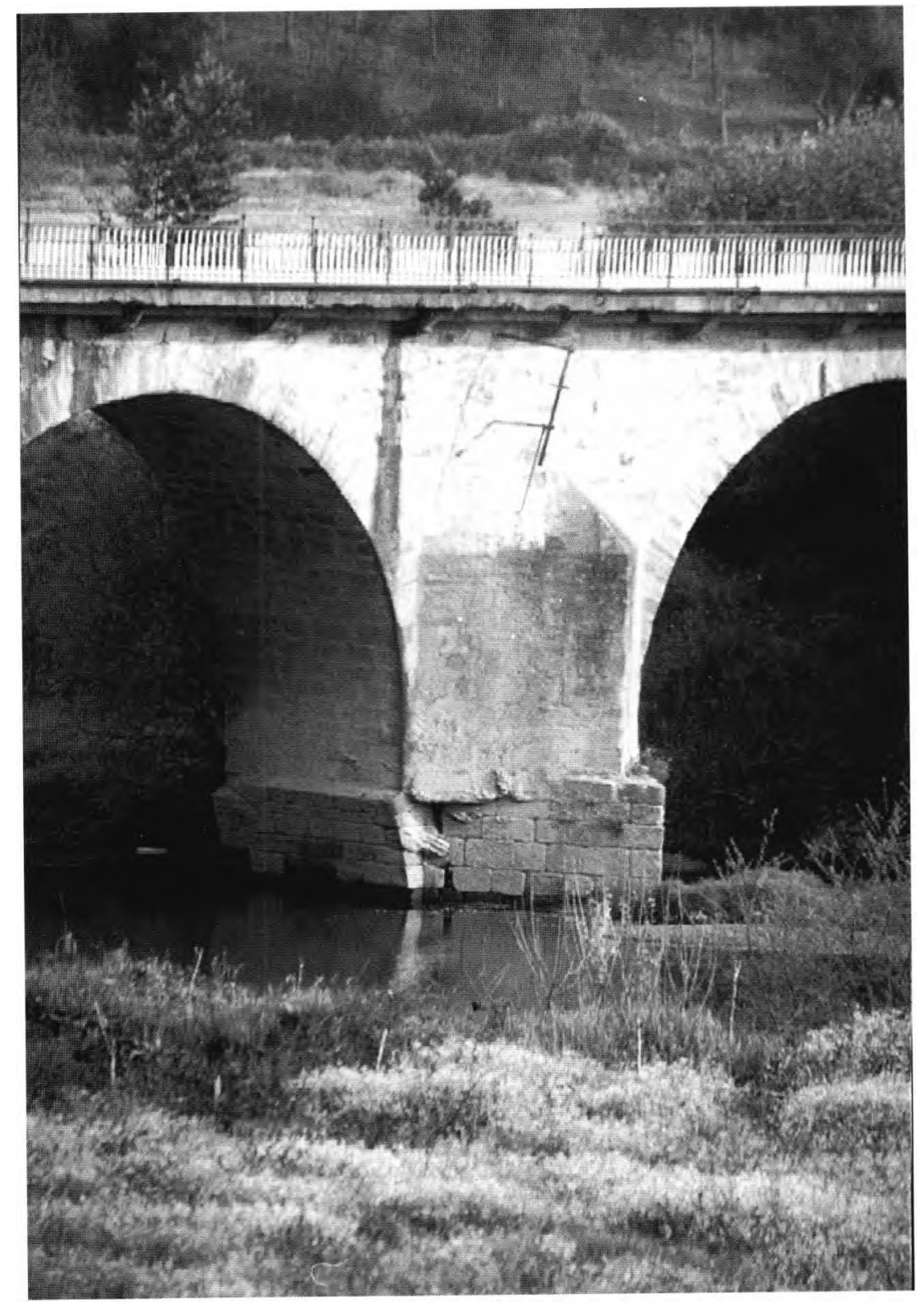

Figura 4 - Um dos pilares da ponte do Vouga, em que se vê o arranque dos arcos da ponte medieval 


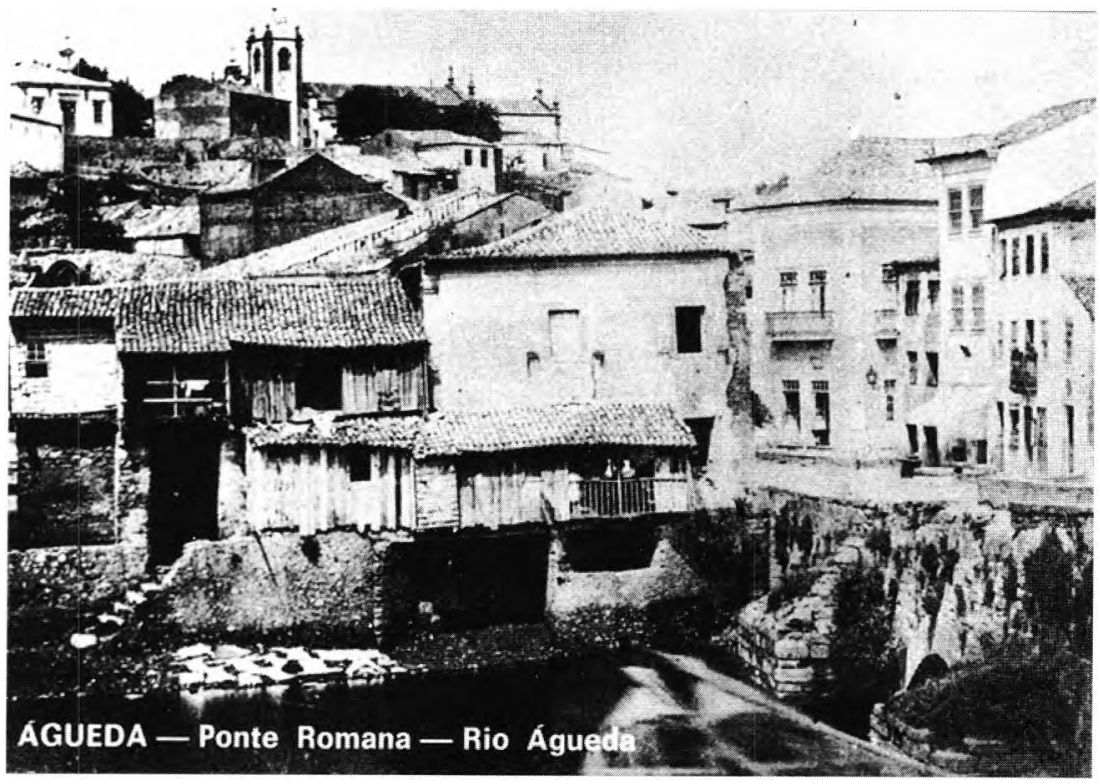

FIgURA 5 - A ponte filipina de Águeda em finais do século XIX (postal editado pelos Serviços de Turismo da Cámara Municipal de Águeda, 1990)

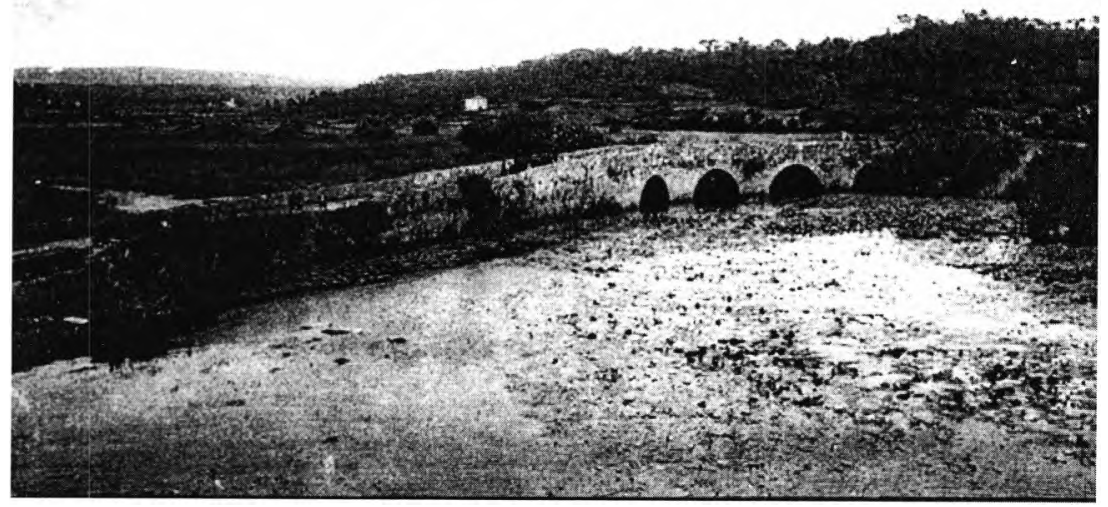

FIGURA 6 - A pateira do Marnel, rodeando a velha ponte (postal antigo) 


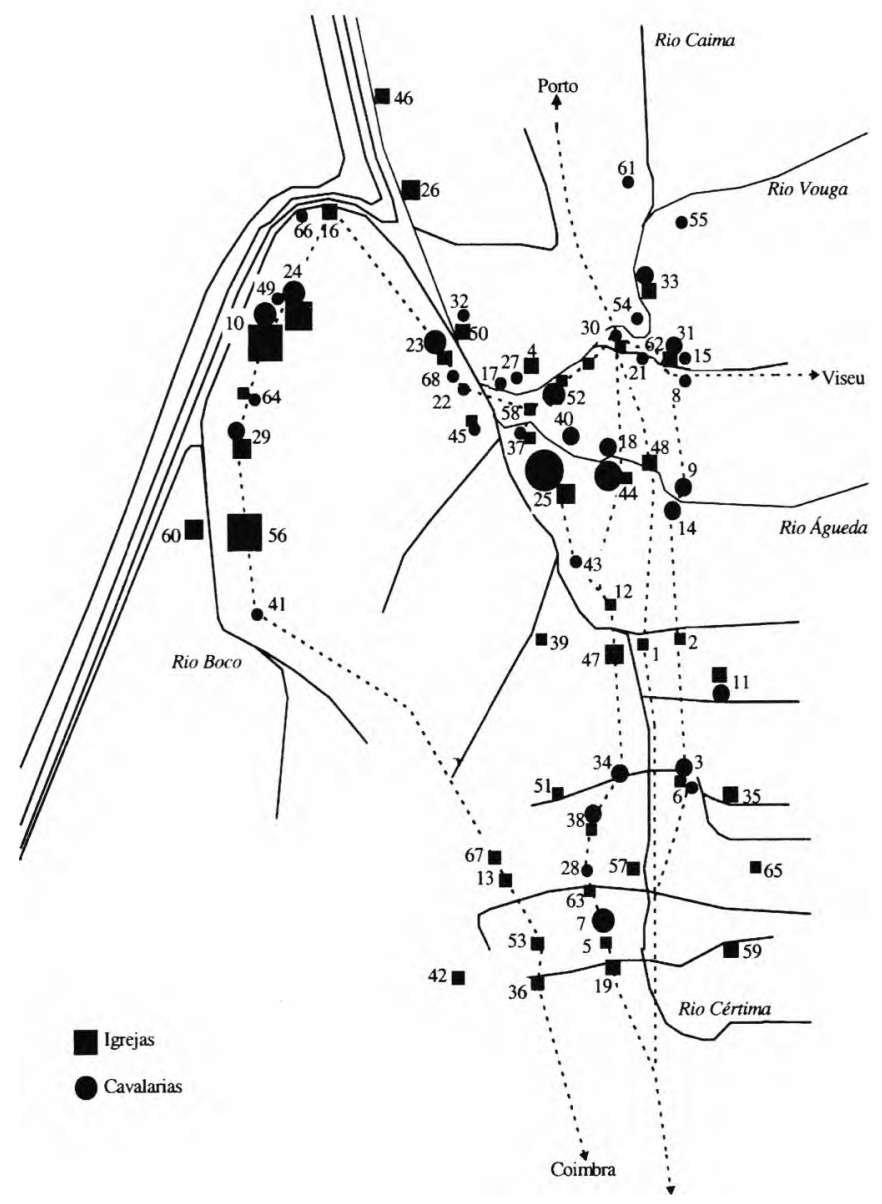

Legenda: 1 - Aguada de Baixo; 2 - Aguada de Cima; 3 - Alféloas; 4 - Alquerubim; 5 - Antes; 6 - Arcos; 7 -

Arinhos; 8 - Arrancada; 9 - Assequins; 10 - Aveiro; 11 - Avelãs de Cima; 12 - Barró; 13 - Bolho; 14 - Borralha; 15 - Branhido; 16 - Cada; 17 - Calvães; 18 - Casainho; 19 - Casal Comba; 20 - Covelas; 21 - Cristelo; 22 - Eirol; 23 Eixo; 24 - Esgueira; 25 - Espinhei; 26 - Fermelã; 27 - Fontes; 28 - Horta; 29 - Ilhavo; 30 - Lamas do Vouga; 31 Lanheses; 32 - Loure; 33 - Macinhata; 34 - Mogofores; 35 - Moita; 36 - Murtede; 37 - Ois da Ribeira; 38 - Ois do Bairro; 39 - Oliveira do Bairro; 40 - Oronhe; 41 - Ouca; 42 - Ourentã; 43 - Paradela; 44 - Recardães; 45 Requeixo; 46 - Salreu; 47 - Sangalhos; 48 - Santa Eulália; 49 - Sá; 50 - São João de Loure; 51 - São Lourenço do Bairro; 52 - Segadães; 53 - Sepins; 54 - Serém; 55 - Soutelo; 56 - Sôza; 57 - Tamçpgos; 58 - Travassô; 59 Vacariça; 60 - Vagos; 61 - Valmaior; 62 - Valongo do Vouga; 63 - Ventosa do Bairro; 64 - Verdemilho; 65 - Vila Nova de Monsarros; 66 - Vilarinho de Cacia; 67 - Vilarinho do Bairro; 68 - Horta (de Eixo).

FIGURA 7 - Distribuição das cavalarias e igrejas na região do Vouga c. 1300 


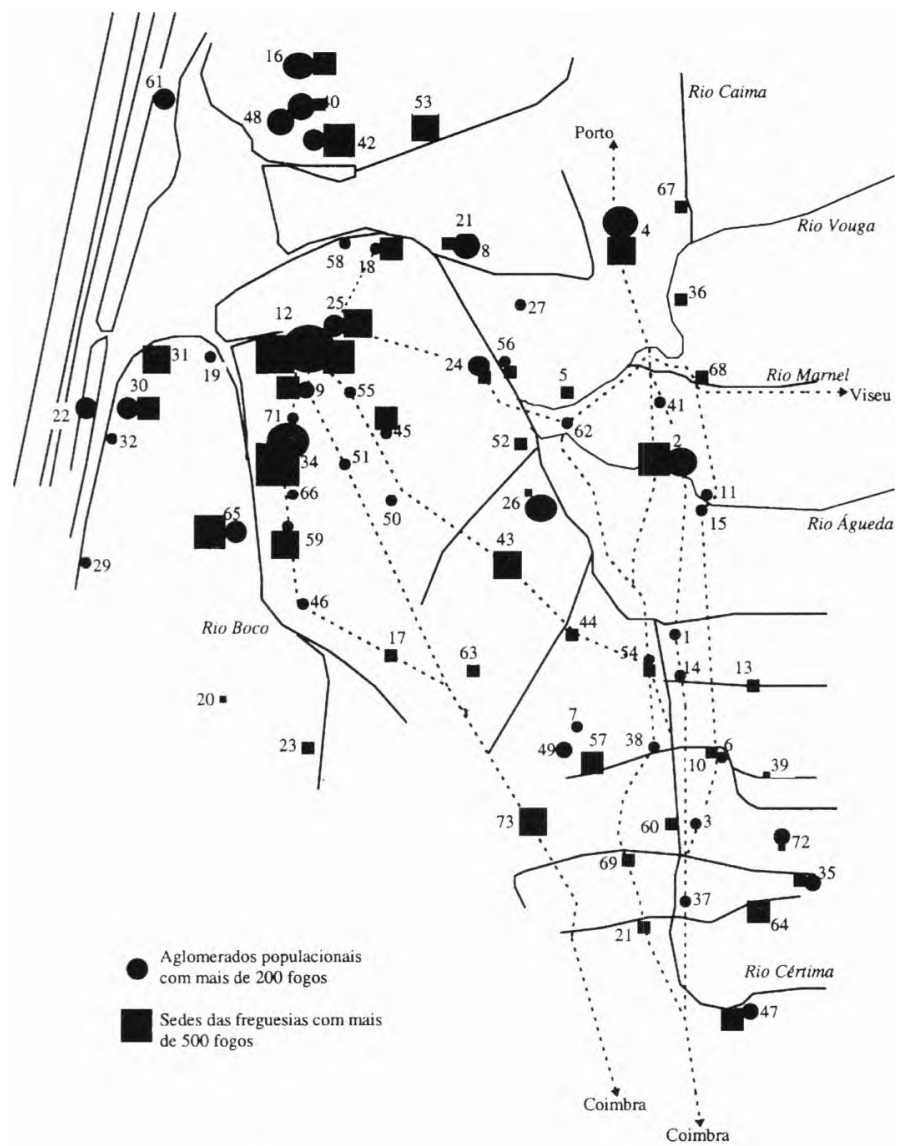

Legenda: 1 - Aguada de Baixo; 2 - Agueda; 3 - Aguim; 4 - Albergaria-a-Velha; 5 - Alquerubim; 6 - Anadia; 7 Ancas; 8 - Angeja; 9 - Arada; 10 - Arcos; 11 - Assequins; 12 - Aveiro; 13 - Avelãs de Cima; 14 - Avelãs do Caminho; 15 - Borralha; 16 - Bunheiro; 17 - Bustos; 18 - Cacia; 19 - Cale da Vila; 20 - Calvão; 21 - Casal Comba; 22 - Costa Nova; 23 - Covão do Lobo; 24 - Eixo; 25 - Esgueira; 26 - Ferméntelos; 27 - Frossos; 29 - Gafanha da Boa Hora; 30 - Gafanha da Encarnação; 31 - Gafanha da Nazaré; 32 - Gafanha do Carmo; 33 - Gloria (Aveiro); 34 - Ilhavo; 35 - Luso; 36 - Macinhata do Vouga; 37 - Mealhada; 38 - Mogofores; 39 - Moita; 40 - Monte; 41 Mourisca; 42 - Murtosa; 43 - Oiã; 44 - Oliveira do Bairro; 45 - Oliveirinha; 46 - Ouca; 47 - Pampilhosa do Botão; 48 - Pardelhas; 49 - Paredes do Bairro; 50 - Póvoa do Valado; 51 - Quinta do Picado; 52 - Requeixo; 53 - Salreu; 54 - Sangalhos; 55 - São Bernardo; 56 - São João de Loure; 57 - São Lourenço do^Bairro; 58 - Sarrazola; 59 Soza; 60 - Tamengos; 61 - Torreira; 62 - Travassô; 63 - Troviscal; 64 - Vacariça; 65 - Vagos; 66 - Vale de llhavo; 67 - Vale Maior; 68 - Valongo do Vouga; 69 - Ventosa do Bairro; 70 - Vera Cruz (Aveiro); 71 - Verdemilho; 72 Vila Nova de Monsarros; 73 - Vilarinho do Bairro.

FIGURA 8 - Principais aglomerados populacionais e sedes das maiores freguesias na região do Vouga segundo o censo de 1940 

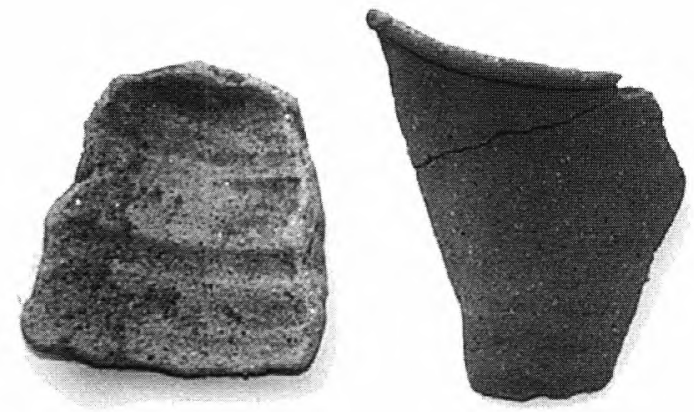

(a)
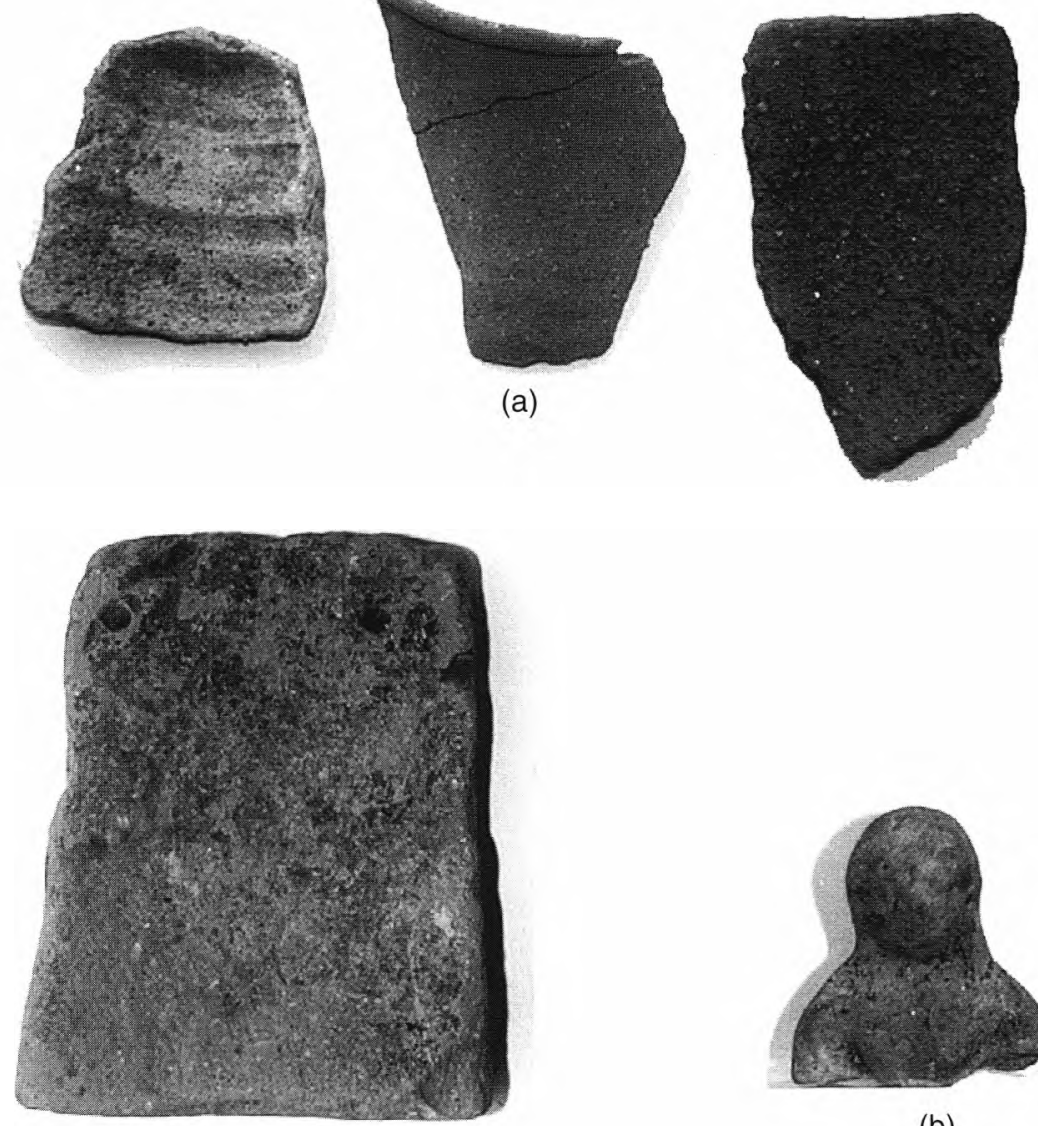

(c)

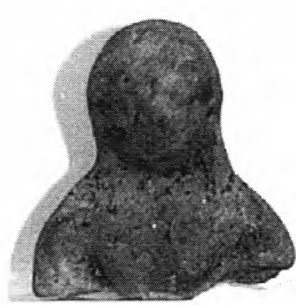

(b)

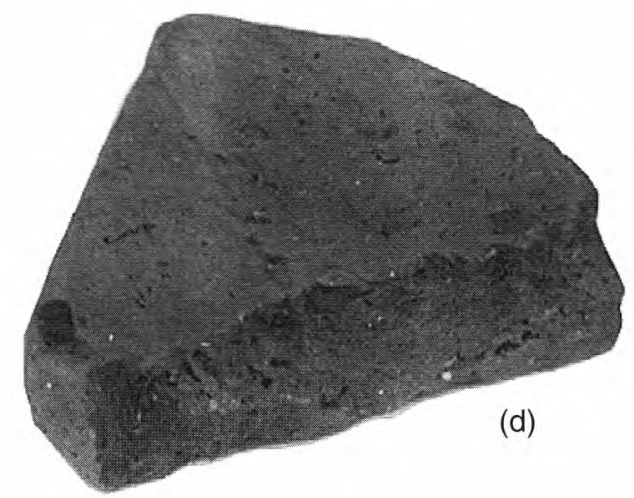

FIgURA 9 - Objectos encontrados nas Sortes, próximo de Sangalhos do Paço:

(a) Cerâmica doméstica; (b) Figura humana em terracota; (c) Peso de tear; (d) Tijolo de coluna. Colecção de L. Malheiro. 


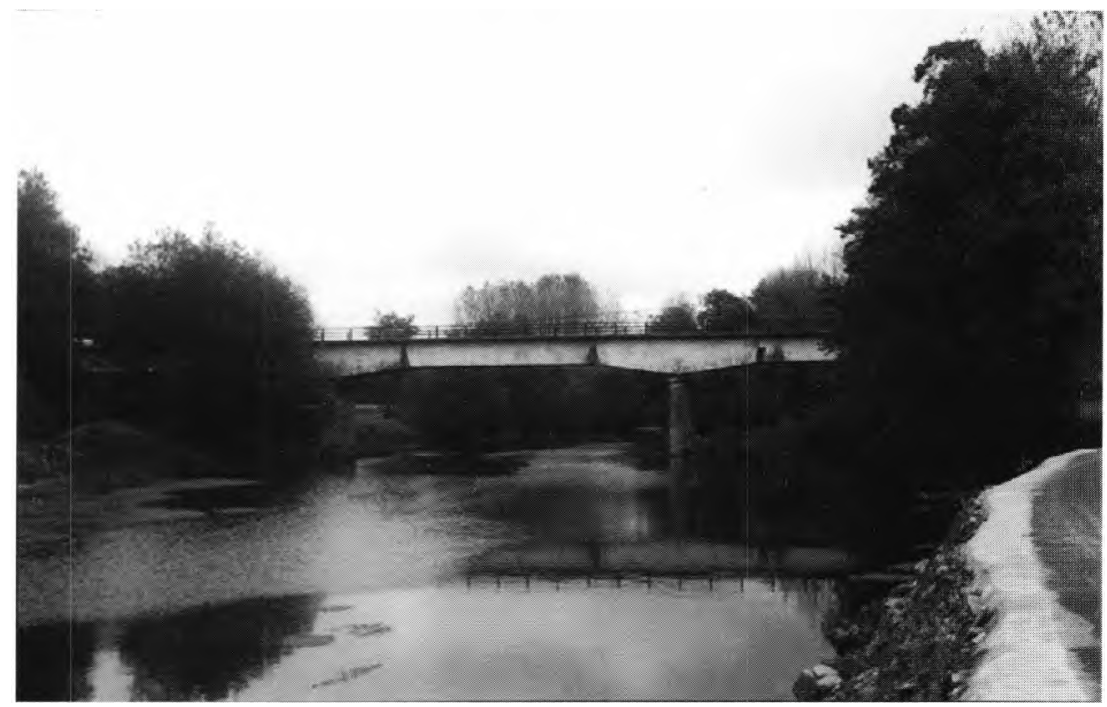

FIgURA 10 - Um antigo local de travessia do rio Águeda, junto a Óis da Ribeira

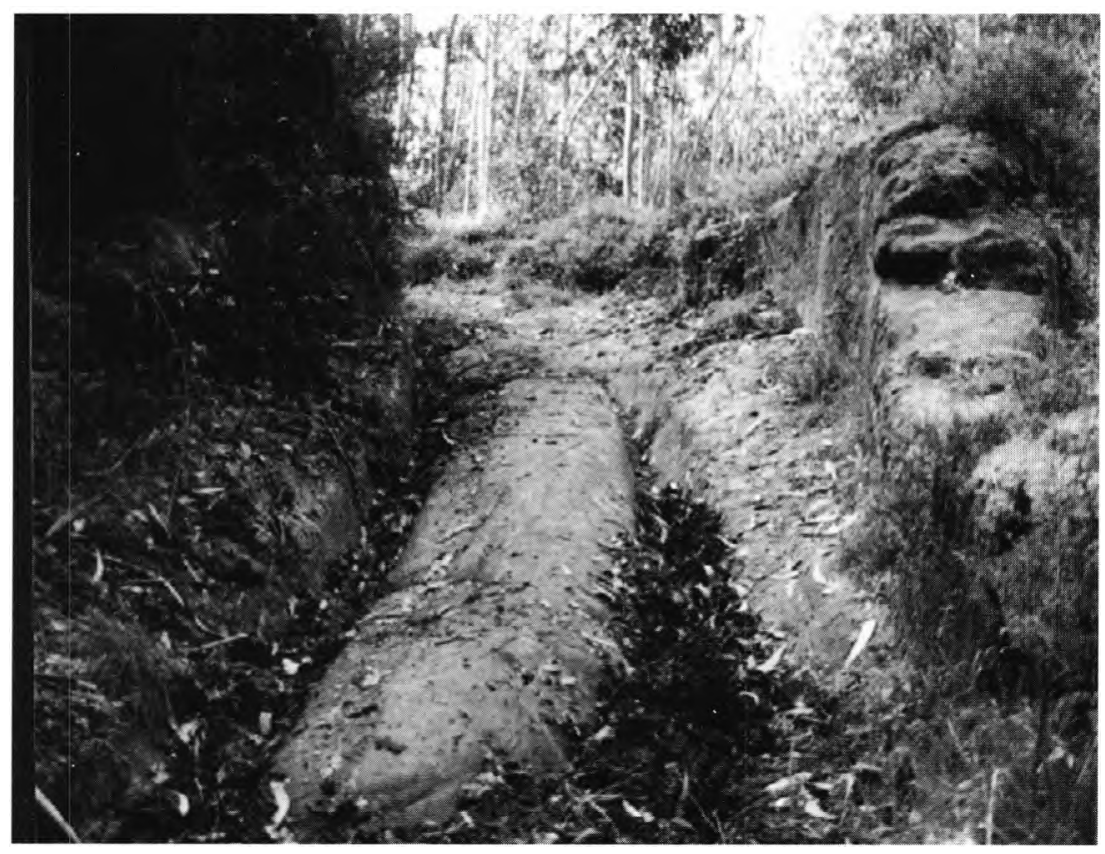

FiguRA 11 - Calçada escavada na rocha em Travassô (Hortinhas/Mato Crespo) 


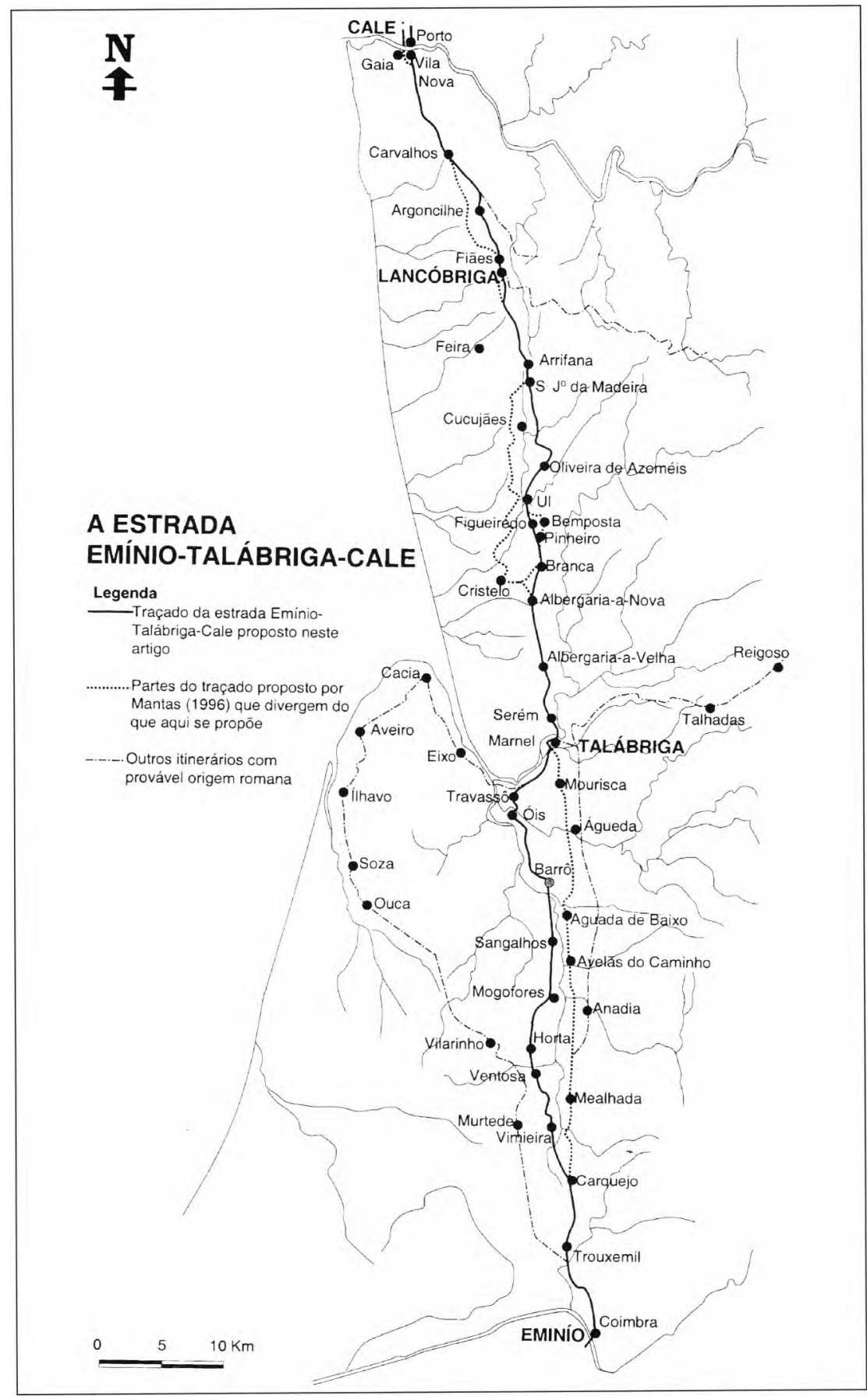

FIGURA 12 